DOE/ID-22197

Prepared in cooperation with the U.S. Department of Energy

\title{
An Update of Hydrologic Conditions and Distribution of Selected Constituents in Water, Snake River Plain Aquifer, Idaho National Laboratory, Idaho, Emphasis 1999-2001
}

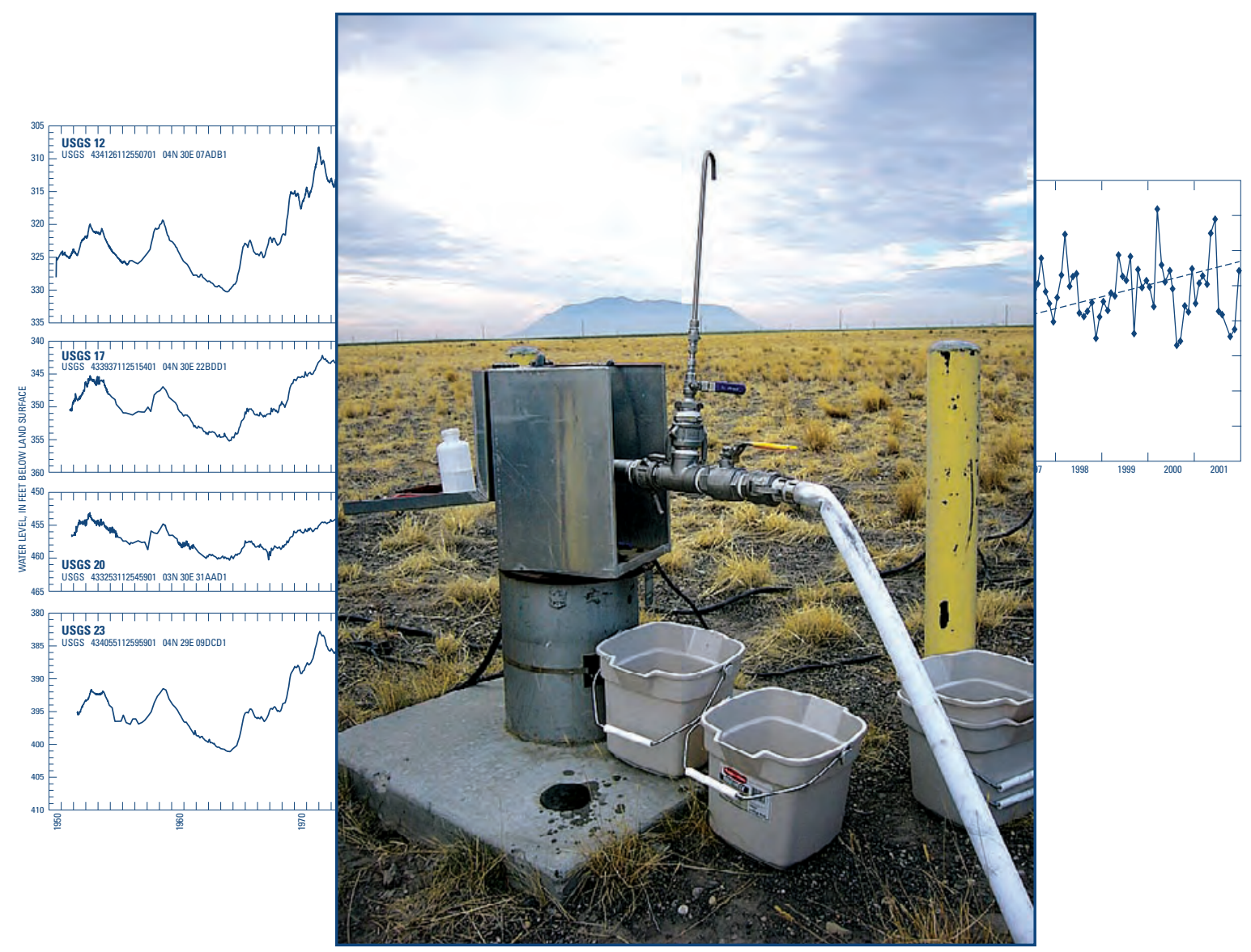

Scientific Investigations Report 2006-5088 
Cover: Photograph of U.S. Geological Survey well and sampling apparatus at the Idaho National Laboratory, Idaho. View looking southwest. Photograph courtesy of the U.S.

Geological Survey Idaho National Laboratory project office. 


\section{An Update of Hydrologic Conditions and Distribution of Selected Constituents in Water, Snake River Plain Aquifer, Idaho National Laboratory, Idaho, Emphasis 1999-2001}

By Linda C. Davis

Prepared in cooperation with the

U.S. Department of Energy

Scientific Investigations Report 2006-5088 


\section{U.S. Department of the Interior \\ Dirk Kempthorne, Secretary \\ U.S. Geological Survey \\ P. Patrick Leahy, Acting Director}

U.S. Geological Survey, Reston, Virginia: 2006

For sale by U.S. Geological Survey, Information Services
Box 25286, Denver Federal Center
Denver, CO 80225
For more information about the USGS and its products:
Telephone: 1-888-ASK-USGS
World Wide Web: http://www.usgs.gov/

Any use of trade, product, or firm names in this publication is for descriptive purposes only and does not imply endorsement by the U.S. Government.

Although this report is in the public domain, permission must be secured from the individual copyright owners to reproduce any copyrighted materials contained within this report.

Suggested citation:

Davis, L.C., 2006, An update of hydrologic conditions and distribution of selected constituents in water, Snake River Plain Aquifer, Idaho National Laboratory, Idaho, emphasis 1999-2001: U.S. Geological Survey Scientific Investigations Report 2006-5088, 48 p. 


\section{Contents}

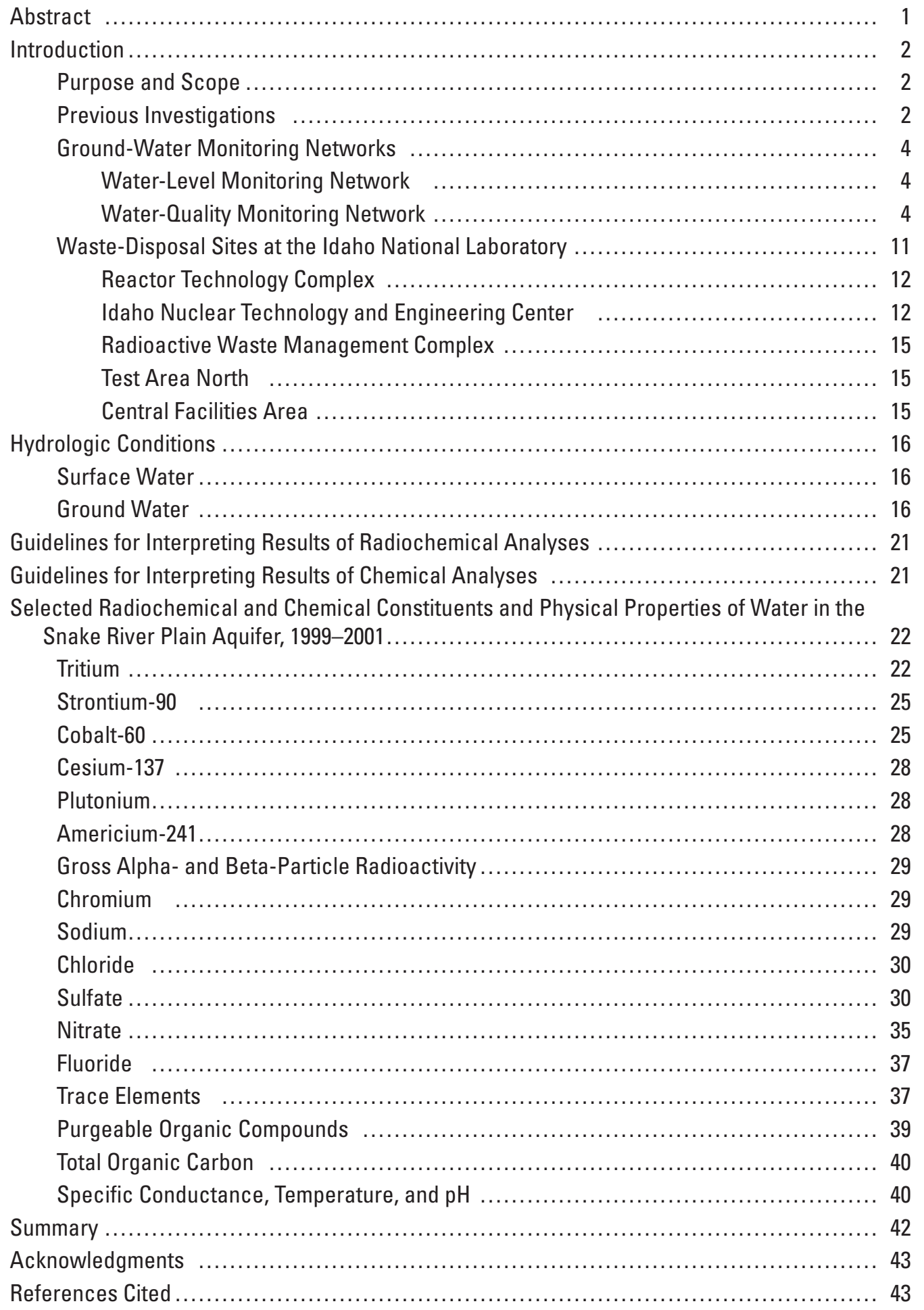




\section{Figures}

Figure 1. Map showing location of the Idaho National Laboratory (INL), surface-water gaging stations, and selected facilities, Idaho

Figure 2. Map showing location of wells in the U.S. Geological Survey water-level monitoring network at and near the Idaho National Laboratory (INL), Idaho, and frequency of water-level measurements, as of December 2001

Figure 3. Map showing location of wells in the U.S. Geological Survey water-level monitoring network at the Reactor Technology Complex (RTC), Idaho Nuclear Technology and Engineering Center (INTEC), and Radioactive Waste Management Complex (RWMC), at the Idaho National Laboratory (INL), Idaho, and frequency of water-level measurements, as of December 2001

Figure 4. Map showing location of wells in the U.S. Geological Survey water-quality monitoring network at the Idaho National Laboratory (INL) and vicinity, Idaho, and frequency of water-sample collections, as of December 2001

Figure 5. Map showing location of wells in the U.S. Geological Survey water-quality monitoring network at the Reactor Technology Complex (RTC), Idaho Nuclear Technology and Engineering Center (INTEC), and Radioactive Waste Management Complex (RWMC) at the Idaho National Laboratory (INL) and vicinity, Idaho, and frequency of water-sample collections, as of December 2001

Figure 6. Graphs showing amount of tritium discharged, tritium as a percentage of total radioactive constituents in wastewater discharged, and volume of wastewater discharged to the radioactive-waste infiltration and evaporation ponds at the Reactor Technology Complex (RTC), Idaho, 1962-2001

Figure 7. Graphs showing amount of tritium discharged, tritium as a percentage of total radioactive constituents in wastewater discharged, and volume of wastewater discharged to the disposal well and infiltration ponds at the Idaho Nuclear Technology and Engineering Center (INTEC), Idaho, 1962-2001

Figure 8. Graphs showing discharge at gaging stations along the Big Lost River: Big Lost River below Mackay Reservoir, water years 1904-06, 1912-14, and 1919-2001; Big Lost River below the Idaho National Laboratory (INL) diversion near Arco, and the INL diversion at head near Arco, Idaho, water years 1965-2001.

Figure 9. Map showing altitude of the water table in the Snake River Plain aquifer in the vicinity of the Idaho National Laboratory (INL), Idaho, March-May 2001

Figure 10. Map showing generalized rise or decline in ground-water levels in the Snake River Plain aquifer in the vicinity of the Idaho National Laboratory (INL), Idaho, March-May 1998 to March-May 2001

Figure 11. Graphs showing water levels in four wells in the central part of the Idaho National Laboratory (INL), Idaho, 1950-2001

Figure 12. Map showing distribution of tritium in water from wells at and near the Reactor Technology Complex (RTC), Idaho Nuclear Technology and Engineering Center (INTEC), Central Facilities Area (CFA), and Radioactive Waste Management Complex (RWMC) at the Idaho National Laboratory (INL), Idaho, October 2001 
Figure 13. Map showing distribution of strontium-90 in water from wells at and near the Reactor Technology Complex (RTC), Idaho Nuclear Technology and Engineering Center (INTEC), Central Facilities Area (CFA), and Radioactive Waste Management Complex (RWMC) at the Idaho National Laboratory (INL), Idaho, October 2001.

Figure 14. Map showing distribution of chloride in water from wells at and near the Reactor Technology Complex (RTC), Idaho Nuclear Technology and Engineering Center (INTEC), Central Facilities Area (CFA), and Radioactive Waste Management Complex (RWMC) at the Idaho National Laboratory (INL), Idaho, October 2001

Figure 15. Map and graph showing amount of chloride in wastewater discharged to the disposal well and infiltration ponds at the Idaho Nuclear Technology and Engineering Center (INTEC), and the location and amount of chloride in water from wells USGS 37 and USGS 57, Idaho National Laboratory (INL), Idaho, 1971-2001

Figure 16. Map showing distribution of nitrate in water from wells at and near the Reactor Technology Complex (RTC), Idaho Nuclear Technology and Engineering Center (INTEC), Central Facilities Area (CFA), and Radioactive Waste Management Complex (RWMC) at the Idaho National Laboratory (INL), Idaho, October 2001

Figure 17. Graph showing carbon tetrachloride concentrations in water from the Radioactive Waste Management Complex (RWMC) production well, Idaho National Laboratory (INL), Idaho, 1987-2001

Figure 18. Map showing distribution of specific conductance of water from wells at and near the Reactor Technology Complex (RTC), Idaho Nuclear Technology and Engineering Center (INTEC), Central Facilities Area (CFA), and Radioactive Waste Management Complex (RWMC) at the Idaho National Laboratory (INL), Idaho, October 2001.

\section{Tables}

Table 1. Location and construction of wells in the U.S. Geological Survey water-quality monitoring network and sample-collection method and frequency, Snake River Plain aquifer, Idaho National Laboratory, Idaho, as of December 2001

Table 2. Average annual streamflow at gaging stations along the Big Lost River, Idaho, water years 1999-2001

Table 3. Tritium concentrations in water from selected wells at and near the Central Facilities Area and the Idaho Nuclear Technology and Engineering Center, Idaho National Laboratory, Idaho, 1980-2001

Table 4. Strontium-90 concentrations in water from selected wells at and near the Idaho Nuclear Technology and Engineering Center, Idaho National Laboratory, Idaho, 1980-2001

Table 5. Sodium concentrations in water from selected wells at and near the Central Facilities Area and the Idaho Nuclear Technology and Engineering Center, Idaho National Laboratory, Idaho, 1981-2001

Table 6. Chloride concentrations in water from selected wells at and near the Central Facilities Area and the Idaho Nuclear Technology and Engineering Center, Idaho National Laboratory, Idaho, 1980-2001 


\section{Conversion Factors, Datums, Abbreviations, Acronyms, and Symbols}

Conversion Factors

\begin{tabular}{lcl}
\hline Multiply & By & To obtain \\
\hline acre & 0.4047 & Hectare \\
acre-foot (acre-ft) & 1,233 & cubic meter \\
acre-foot per day (acre-ft/d) & 0.01427 & cubic meter per second \\
cubic foot per second per mile $[(\mathrm{ft} 3 / \mathrm{s}) / \mathrm{mi}]$ & 0.01760 & cubic meter per second per kilometer \\
Curie (Ci) & $3.7 \times 10^{10}$ & becquerel \\
foot (ft) & 0.3048 & meter \\
gallon (gal) & 3.785 & liter \\
inch (in.) & 25.4 & millimeter \\
mile (mi) & 1.609 & kilometer \\
million gallons per day (Mgal/d) & 0.04381 & cubic meter per second \\
picocurie per liter (pCi/L) & 0.037 & becquerel per liter \\
picocurie per milliliter $(\mathrm{pCi} / \mathrm{mL})$ & 0.037 & becquerel per milliliter \\
pound, avoirdupois (lb) & 0.4536 & kilogram \\
square mile (mi2) & 2.590 & square kilometer \\
\hline
\end{tabular}

Temperature in degrees Celsius $\left({ }^{\circ} \mathrm{C}\right)$ may be converted to degrees Fahrenheit $\left({ }^{\circ} \mathrm{F}\right)$ as follows:

$$
{ }^{\circ} \mathrm{F}=\left(1.8 x^{\circ} \mathrm{C}\right)+32
$$

Datums

Vertical coordinate information is referenced to the National Geodetic Vertical Datum of 1929 (NGVD 29).

Horizontal coordinate information is referenced to the North American Datum of 1927 (NAD 27).

Altitude, as used in this report, refers to distance above the vertical datum.

Specific conductance is given in microsiemens per centimeter at 25 degrees Celsius $(\mu \mathrm{S} / \mathrm{cm}$ at $\left.25^{\circ} \mathrm{C}\right)$.

Concentrations of chemical constituents in water are given either in milligrams per liter $(\mathrm{mg} / \mathrm{L})$ or micrograms per liter $(\mu \mathrm{g} / \mathrm{L})$. 
Abbreviations, Acronyms, and Symbols

\begin{tabular}{|c|c|}
\hline $\begin{array}{l}\text { Abbreviation, Acronyms, } \\
\text { and Symbols }\end{array}$ & Definition \\
\hline $\mathrm{Ci}$ & Curie \\
\hline CFA & Central Facilities Area \\
\hline DOE & Department of Energy \\
\hline ICPP & Idaho Chemical Processing Plant \\
\hline INEEL & Idaho National Engineering and Environmental Laboratory (1997-2005) \\
\hline INEL & Idaho National Engineering Laboratory (1974-97) \\
\hline INL & Idaho National Laboratory \\
\hline INTEC & Idaho Nuclear Technology and Engineering Center \\
\hline LRL & laboratory reporting level \\
\hline LT-MDL & long-term method detection level \\
\hline $\mathrm{mg} / \mathrm{L}$ & milligram per liter \\
\hline MCL & maximum contaminant level \\
\hline MRL & minimum reporting level \\
\hline $\mathrm{NRF}$ & Naval Reactors Facility \\
\hline NRTS & National Reactor Testing Station (1949-79) \\
\hline NWIS & National Water Information System \\
\hline NWQL & National Water Quality Laboratory (USGS) \\
\hline $\mathrm{pCi} / \mathrm{L}$ & picocurie per liter \\
\hline $\mathrm{pCi} / \mathrm{mL}$ & picocurie per milliliter \\
\hline POC & purgeable organic compound \\
\hline RESL & Radiological and Environmental Sciences Laboratory (DOE) \\
\hline RTC & Reactor Technology Complex \\
\hline RWMC & Radioactive Waste Management Complex \\
\hline$s$ & sample standard deviation \\
\hline SDA & Subsurface Disposal Area \\
\hline TAN & Test Area North \\
\hline TOC & total organic carbon \\
\hline$\mu \mathrm{g} / \mathrm{L}$ & microgram per liter \\
\hline USGS & U.S. Geological Survey \\
\hline$<$ & less than \\
\hline \pm & plus or minus \\
\hline
\end{tabular}


This page intentionally left blank. 


\title{
An Update of Hydrologic Conditions and Distribution of Selected Constituents in Water, Snake River Plain Aquifer, Idaho National Laboratory, Idaho, Emphasis 1999-2001
}

\author{
By Linda C. Davis
}

\section{Abstract}

Radiochemical and chemical wastewater discharged since 1952 to infiltration ponds, evaporation ponds, and disposal wells at the Idaho National Laboratory (INL) has affected water quality in the Snake River Plain aquifer underlying the INL. The U.S. Geological Survey (USGS), in cooperation with the U.S. Department of Energy, maintains ground-water monitoring networks at the INL to determine hydrologic trends, and to delineate the movement of radiochemical and chemical wastes in the aquifer. This report presents an analysis of water-level and water-quality data collected from wells in the USGS ground-water monitoring networks during 1999-2001.

Water in the Snake River Plain aquifer moves principally through fractures and interflow zones in basalt, generally flows southwestward, and eventually discharges at springs along the Snake River. The aquifer is recharged principally from infiltration of irrigation water, infiltration of streamflow, ground-water inflow from adjoining mountain drainage basins, and infiltration of precipitation. Water levels in wells rose in the northern and west-central parts of the INL by 1 to 3 feet, and declined in the southwestern parts of the INL by up to 4 feet during 1999-2001.

Detectable concentrations of radiochemical constituents in water samples from wells in the Snake River Plain aquifer at the INL generally decreased or remained constant during 1999-2001. Decreases in concentrations were attributed to decreased rates of radioactive-waste disposal, radioactive decay, changes in waste-disposal methods, and dilution from recharge. Tritium concentrations in water samples decreased as much as 8.3 picocuries per milliliter $(\mathrm{pCi} / \mathrm{mL})$ during $1999-2001$, ranging from $0.43 \pm 0.14$ to $13.6 \pm 0.6 \mathrm{pCi} / \mathrm{mL}$ in October 2001. Tritium concentrations in five wells near the Idaho Nuclear Technology and Engineering Center (INTEC) increased a few picocuries per milliliter from October 2000 to October 2001. Strontium-90 concentrations decreased or remained constant during 1999-2001, ranging from $2.1 \pm 0.6$ to $42.4 \pm 1.4 \mathrm{pCi} / \mathrm{L}$ in October 2001. During 1999-2001, concentrations of cesium-137, plutonium-238, and plutonium-239, -240 (undivided) were less than the reporting level in water samples from all wells sampled at the INL. The concentration of americium-241 in one sample was $0.003 \pm 0.001 \mathrm{pCi} / \mathrm{L}$, the reporting level for that constituent. Cobalt-60 was not detected in any samples collected during 1999-2001.

Changes in detectable concentrations of nonradioactive chemical constituents in water from the Snake River Plain aquifer at the INL varied during 1999-2001. In October 2001, water from one well south of the Reactor Technology Complex (RTC) [known as the Test Reactor Area (TRA) until 2005] contained 139 micrograms per liter $(\mu \mathrm{g} / \mathrm{L})$ of chromium, a decrease from the concentration of $168 \mu \mathrm{g} / \mathrm{L}$ detected in October 1998. Other water samples contained from less than 16.7 to $21.3 \mu \mathrm{g} / \mathrm{L}$ of chromium. In October 2001, concentrations of sodium in water samples from most of the wells in the southern part of the INL were larger than the background concentration of $10 \mathrm{mg} / \mathrm{L}$, but were similar to or slightly less than October 1998 concentrations. The largest sodium concentration was 75 milligrams per liter $(\mathrm{mg} / \mathrm{L})$ in water from well USGS 113.

In 2001, chloride concentrations in most water samples from the INTEC and the Central Facilities Area (CFA) exceeded ambient concentrations of 10 and $20 \mathrm{mg} / \mathrm{L}$, respectively. Chloride concentrations in water from wells near the RTC were less than $20 \mathrm{mg} / \mathrm{L}$. At the Radioactive Waste Management Complex (RWMC), chloride concentrations in water from wells USGS 88, 89, and 120 were 81, 40, and 23 $\mathrm{mg} / \mathrm{L}$, respectively. Concentrations of chloride in all other wells near the RWMC were less than $19 \mathrm{mg} / \mathrm{L}$. During 2001, concentrations of sulfate in water from two wells near the RTC, two wells near the RWMC, and one well near the CFA exceeded $40 \mathrm{mg} / \mathrm{L}$, the estimated background concentration of sulfate in the Snake River Plain aquifer at the INL.

In 2001, concentrations of nitrate in water from wells USGS 40, 43, 77, and CFA 1 were 16, 21, 16, and $14 \mathrm{mg} / \mathrm{L}$ as nitrate, respectively. These generally were smaller concentrations than those in 1998, with the exception of the concentration in water from well USGS 40, which had slightly increased. However, since 1981, there has been an overall decrease in nitrate concentration in water from these wells. 
During 1999-2001, water samples from 12 wells were analyzed for fluoride; detected concentrations ranged from 0.2 to $0.3 \mathrm{mg} / \mathrm{L}$. These concentrations are similar to background concentrations, indicating that wastewater disposal has not had an appreciable affect on fluoride concentrations in the Snake River Plain aquifer near the INTEC.

During 1999-2001, 10 purgeable organic compounds (POCs) were detected in water from wells at the INL. Water samples from 17 wells contained from 1 to 5 of these POCs in October 2001. Concentrations of 1,1,1-trichloroethane were greater than the reporting level in samples from four wells near the INTEC. Concentrations of several POCs exceeded their minimum reporting levels in wells at or near the RWMC.

\section{Introduction}

The Idaho National Laboratory (INL) is operated by the U.S. Department of Energy (DOE) and encompasses about $890 \mathrm{mi}^{2}$ of the eastern Snake River Plain in southeastern Idaho (fig. 1). Names formerly used for this site, from earliest to most recent, were National Reactor Testing Station (NRTS, from 1949 to 1974), Idaho National Engineering Laboratory (INEL, from 1974 to 1997), and Idaho National Engineering and Environmental Laboratory (INEEL, from 1997 to 2005). The INL facilities are used in the development of peacetime atomic-energy applications, nuclear safety research, defense programs, environmental research, and advanced energy concepts. Radiochemical and chemical wastewater generated at these facilities has been discharged to either onsite infiltration ponds, evaporation ponds, disposal wells, or a combination thereof, since 1952. Wastewater disposal has resulted in detectable concentrations of several waste constituents in water from the Snake River Plain aquifer underlying the INL.

The DOE requires information about the mobility of dilute radiochemical- and chemical-waste constituents in the Snake River Plain aquifer. Waste-constituent mobility is determined, in part, by (1) the rate and direction of groundwater flow; (2) the locations, quantities, and methods of waste disposal; (3) waste-constituent chemistry; and (4) the geochemical processes taking place in the aquifer. This study was conducted by the U.S. Geological Survey (USGS) in cooperation with the DOE's Idaho Operations Office.

\section{Purpose and Scope}

In 1949, the U.S. Atomic Energy Commission, which later became the DOE, requested that the USGS describe the water resources of the area now known as the INL. The purpose of the resulting study was to characterize these resources before the development of nuclear-reactor testing facilities. Since that time, the USGS has maintained waterquality and water-level monitoring networks at the INL to determine hydrologic trends and to delineate the movement of radiochemical and chemical wastes in the Snake River Plain aquifer.

This report presents an analysis of water-level and water-quality data collected from wells in the USGS groundwater monitoring networks during 1999-2001 as part of the continuing hydrogeologic investigations conducted by the USGS at the INL. The report describes the distribution and concentration of selected radiochemical and chemical constituents in ground water at the INL, and changes in the water-level regime since 1998.

\section{Previous Investigations}

Several reports that describe the geology and hydrology of the INL have been published; a list of references and copies of reports can be obtained at the USGS INL Project Office or on the USGS Publications Warehouse Web Site at URL http:// infotrek.er.usgs.gov/pubs/.

Ground-water conditions and distribution of selected wastewater constituents in the Snake River Plain aquifer are discussed in a series of annual reports describing the NRTS. The series includes reports by Jones (1961); Olmsted (1962); Morris and others (1963, 1964, 1965); Barraclough and others (1967a); and Barraclough and others (1967b). Nace and others (1975) presented the generalized geologic framework of the NRTS. Robertson and others (1974) presented an analysis of the effects of waste disposal on the geochemistry of ground water at the NRTS. Barraclough and others (1976) gave a comprehensive discussion on the hydrology of the solid waste burial ground, now the Radioactive Waste Management Complex (RWMC). Data on hydrologic conditions at the INL have been described in a series of reports: hydrologic conditions during 1971-73 were described by Barraclough and Jensen (1976), during 1974-78 by Barraclough and others (1981), during 1979-81 by Lewis and Jensen (1985), during $1982-85$ by Pittman and others (1988), during $1986-88$ by Orr and Cecil (1991), during 1989-91 by Bartholomay and others (1995), during 1992-95 by Bartholomay and others (1997), and during 1996-98 by Bartholomay and others (2000).

Cecil and others (1991) discussed mechanisms responsible for formation of perched ground water at the Reactor Technology Complex (RTC) [known as the Test Reactor Area (TRA) until 2005], the Idaho Chemical Processing Plant (ICPP, now the Idaho Nuclear Technology and Engineering Center, or INTEC), and the Radioactive Waste Management Complex (RWMC) and described the distribution of chemical and radiochemical constituents in perched ground water at the RTC, ICPP, and RWMC during 1986-88. The hydrologic conditions and distribution of selected radiochemical and chemical constituents in perched ground water during 1989-91 were described by Tucker and Orr (1998), during 1992-95 by Bartholomay (1998), and during 1996-98 by Bartholomay and Tucker (2000). 


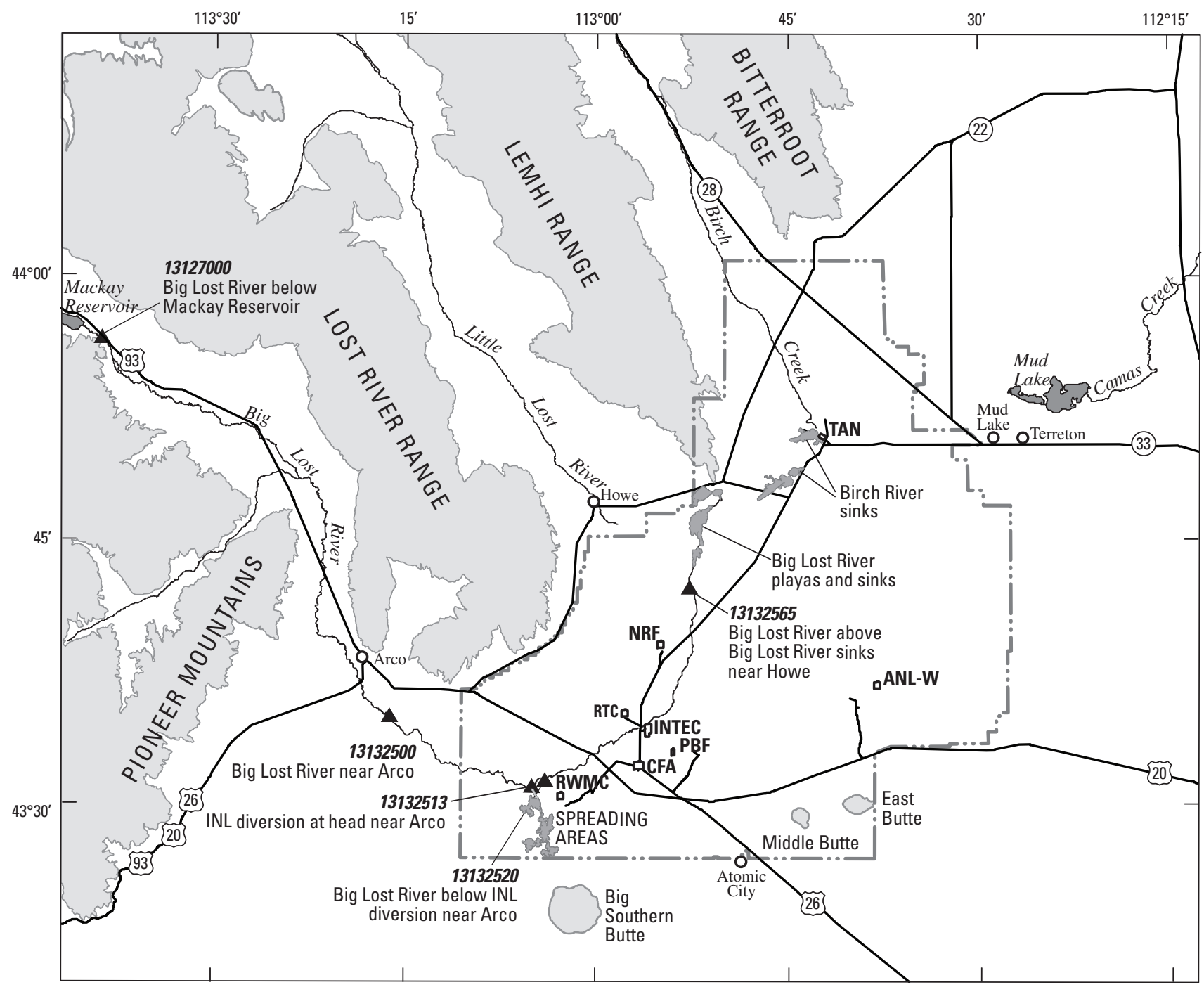

Base from U.S. Geological Survey digital data, 1:24,000 and 1:100,000 Universal Transverse Mercator projection, Zone 12 Datum is North American Datum of 1927

\section{EXPLANATION}
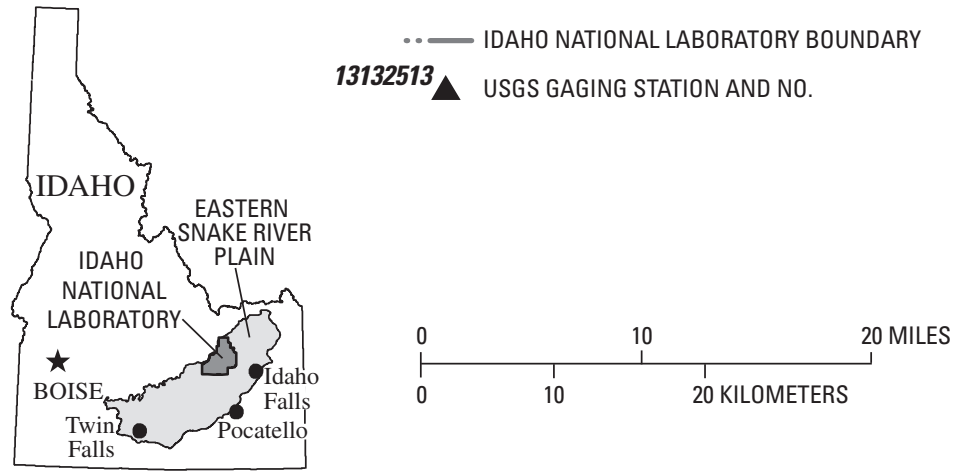

- SELECTED FACILITIES AT THE IDAHO NATIONAL LABORATORY ANL-W ARGONNE NATIONAL LABORATORY-WEST

CFA CENTRAL FACILITIES AREA

INTEC IDAHO NUCLEAR TECHNOLOGY AND ENGINEERING CENTER

NRF NAVAL REACTORS FACILITY

PBF POWER BURST FACILITY

RWMC RADIOACTIVE WASTE MANAGEMENT COMPLEX

RTC REACTOR TECHNOLOGY COMPLEX-Also known as TEST

REACTOR AREA (TRA)

TAN TEST AREA NORTH

Figure 1. Location of the Idaho National Laboratory (INL), surface-water gaging stations, and selected facilities, Idaho. 


\section{Ground-Water Monitoring Networks}

The USGS maintains ground-water monitoring networks at the INL to characterize the occurrence, movement, and quality of water and to delineate waste-constituent plumes in the Snake River Plain aquifer. These networks consist of wells from which periodic water-level and water-quality data are obtained. Data from these monitoring networks are on file at the USGS INL Project Office and are available on the USGS National Water Information System (NWIS) Web Site at URL http://waterdata.usgs.gov/id/nwis/nwis.

\section{Water-Level Monitoring Network}

The water-level monitoring network was designed to determine hydraulic-gradient changes that affect the rate and direction of ground-water and waste-constituent movement in the Snake River Plain aquifer, to identify sources of recharge to the aquifer, and to measure the effects of recharge. Water levels in 153 wells were monitored during 1999-2001. Water levels were measured annually in 27 wells, semiannually in 51 wells, quarterly in 60 wells, monthly in 11 wells, and continuously recorded in 4 wells. Figures 2 and $\underline{3}$ show the location of wells and the frequency of water-level measurements as of December 2001.

\section{Water-Quality Monitoring Network}

The radiochemical and chemical character of water in the Snake River Plain aquifer is determined from analyses of water samples collected as part of a comprehensive sampling program to identify contaminant concentrations and to define the pattern of waste migration in the aquifer. Water samples from surface-water sites at or near the INL and from wells in perched ground-water zones are analyzed to document the chemical quality of water that recharges the aquifer. Water samples are collected from wells that penetrate the aquifer to various depths and with differing well completions and are analyzed to identify trends in water quality. Numerous water samples are collected near areas of detailed study, such as the RTC, INTEC, RWMC, Test Area North (TAN), and Central Facilities Area (CFA). Water samples from the Naval Reactors Facility (NRF) are collected and analyzed as part of a separate study and results are presented in series of separate reports (Bartholomay and others, 2001a, 2001b).

The type, frequency, and depth of ground-water sampling generally depend on the information needed in a specific area. Water samples routinely are collected and analyzed for concentrations of tritium, strontium-90, cobalt-60, cesium-137, plutonium-238, plutonium-239, -240 (undivided), americium-241, gross alpha- and beta-particle radioactivity, chromium, sodium, chloride, sulfate, nitrate, purgeable organic compounds, and measurements of specific conductance, $\mathrm{pH}$, and temperature. In addition, as part of the INL ground-water monitoring program adopted in 1994 (Sehlke and Bickford, 1993), samples from several wells also are analyzed for fluoride, an extensive suite of trace elements, and total organic carbon. Water samples are analyzed for the radiochemical constituents at the Radiological and Environmental Sciences Laboratory (RESL) at the INL and for chemical constituents at the USGS National Water Quality Laboratory (NWQL) in Lakewood, CO. The location of wells in the water-quality monitoring network as of December 2001, and the frequency of sample collection are shown in figures 4 and $\underline{5}$, and in table 1. A sample schedule that lists the constituents analyzed at each site is given in a report by Bartholomay and others (2003, attachment 1).

The methods used in sampling and analyzing for selected constituents generally follow the guidelines established by the USGS (Goerlitz and Brown, 1972; Stevens and others, 1975; Wood, 1976; Claassen, 1982; W.L. Bradford, written commun., 1985; Wershaw and others, 1987; Fishman and Friedman, 1989; Faires, 1993; Fishman, 1993; and Wilde and others, 1998). Water samples analyzed by the NWQL and RESL were collected in accordance with a quality-assurance plan for water-quality activities conducted by personnel at the USGS INL Project Office. The plan was finalized in June 1989, revised in March 1992, in 1996 (Mann, 1996), and in 2003 (Bartholomay and others, 2003) and is available for inspection at the USGS INL Project Office. About 10 percent of the samples generally are collected for quality assurance. Quality-assurance samples include equipment blanks, trip blanks, splits, replicates, and spiked samples. Comparative studies to determine agreement among analytical results for water-sample pairs analyzed by laboratories involved in the USGS INL Project Office quality-assurance program were summarized by Wegner (1989), Williams (1996, 1997), and Williams and others (1998). Additional quality-assurance studies by personnel at the USGS INL Project Office include an evaluation of field-sampling and preservation methods for strontium-90 (Cecil and others, 1989), a comparison of different pump types used for sampling purgeable organic compounds (Knobel and Mann, 1993), an analysis of tritium and strontium-90 concentrations in water from wells after purging different borehole volumes (Bartholomay, 1993), an analysis of the effect of different preservation methods on nutrient concentrations (Bartholomay and Williams, 1996), and an analysis of two analytical methods for the determination of gross alpha- and beta-particle radioactivity (Bartholomay and others, 1999). 


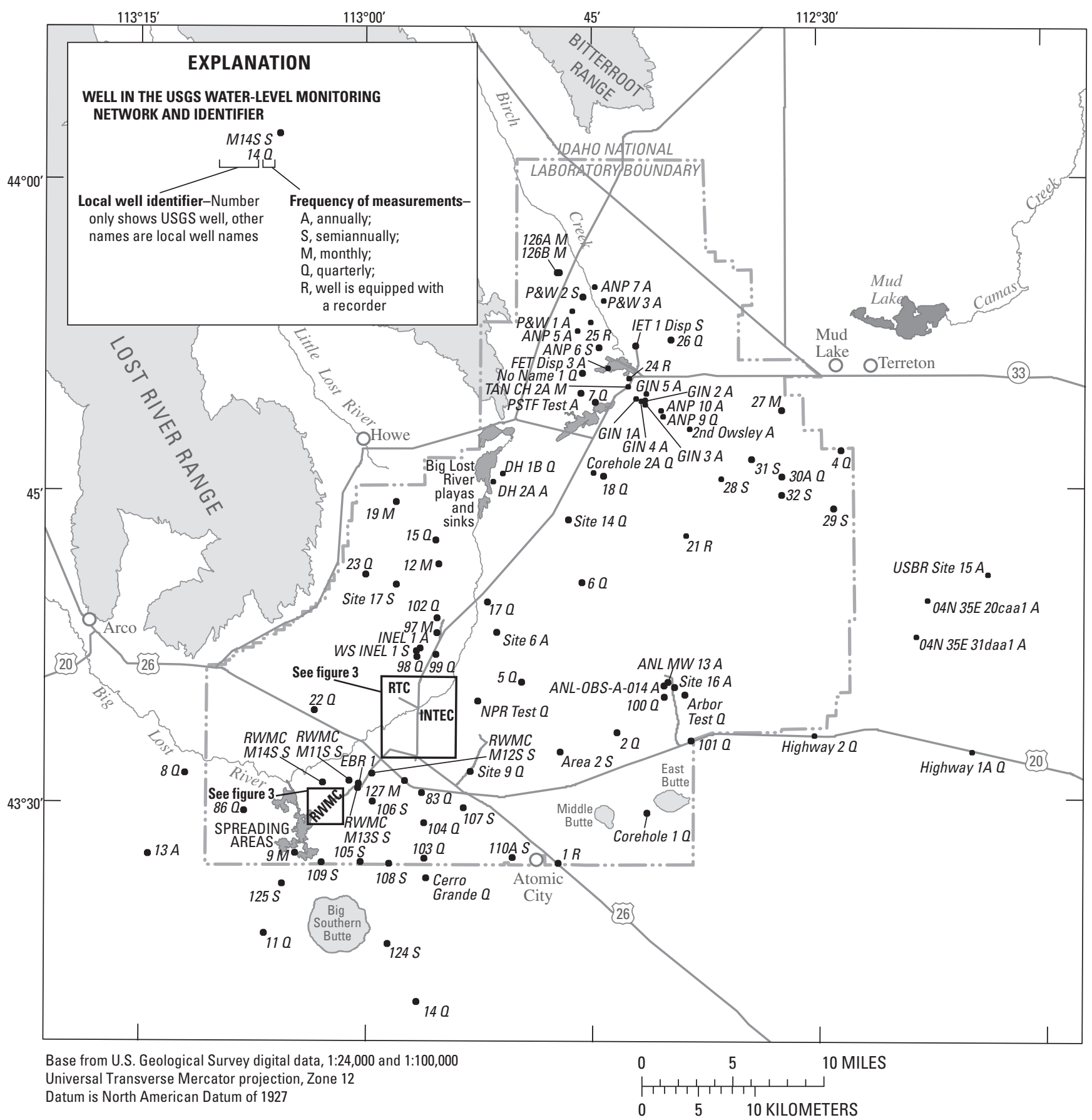

Figure 2. Location of wells in the U.S. Geological Survey water-level monitoring network at and near the Idaho National Laboratory (INL), Idaho, and frequency of water-level measurements, as of December 2001. 


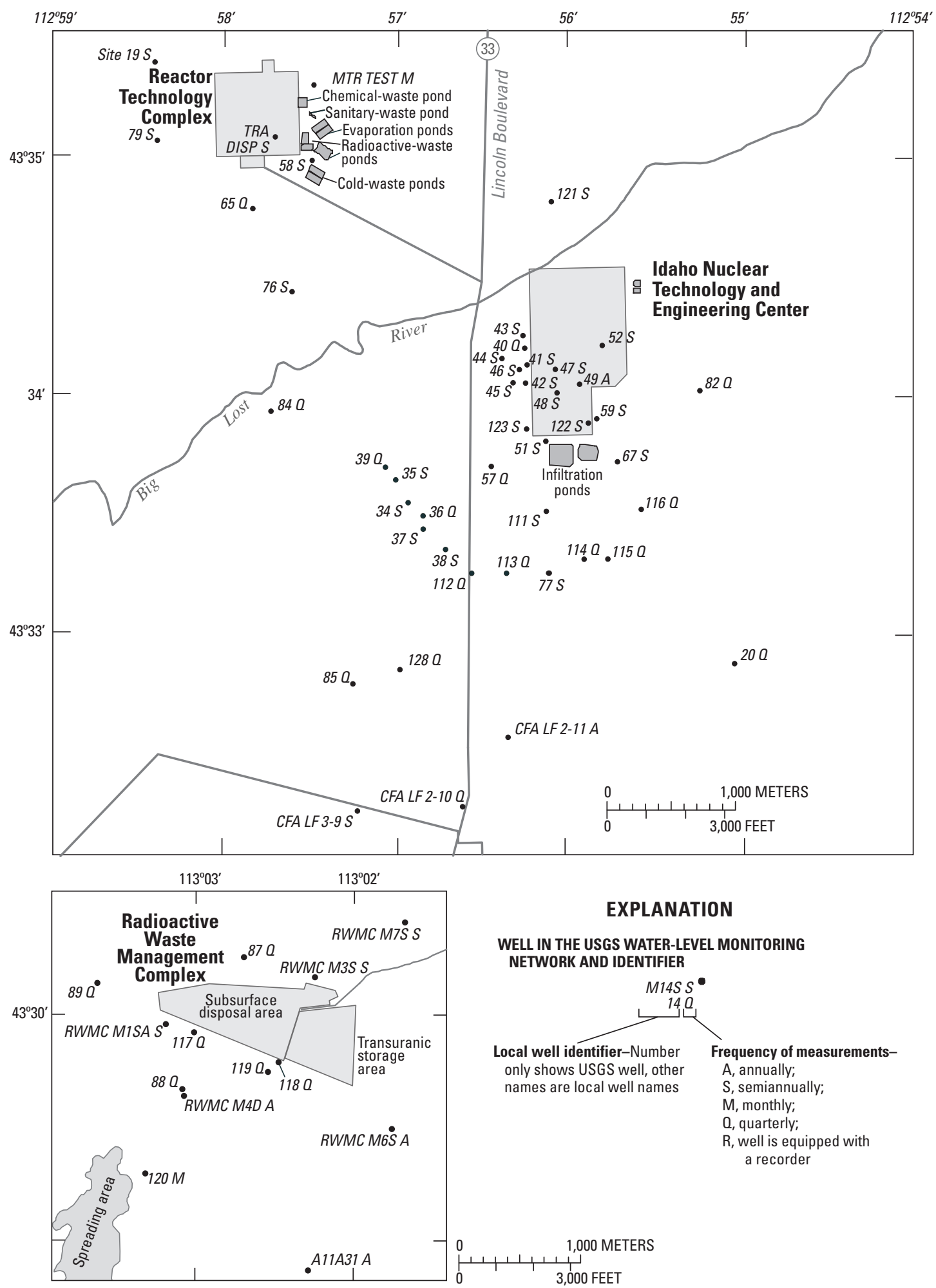

Figure 3. Location of wells in the U.S. Geological Survey water-level monitoring network at the Reactor Technology Complex (RTC), Idaho Nuclear Technology and Engineering Center (INTEC), and Radioactive Waste Management Complex (RWMC), at the Idaho National Laboratory (INL), Idaho, and frequency of water-level measurements, as of December 2001. 


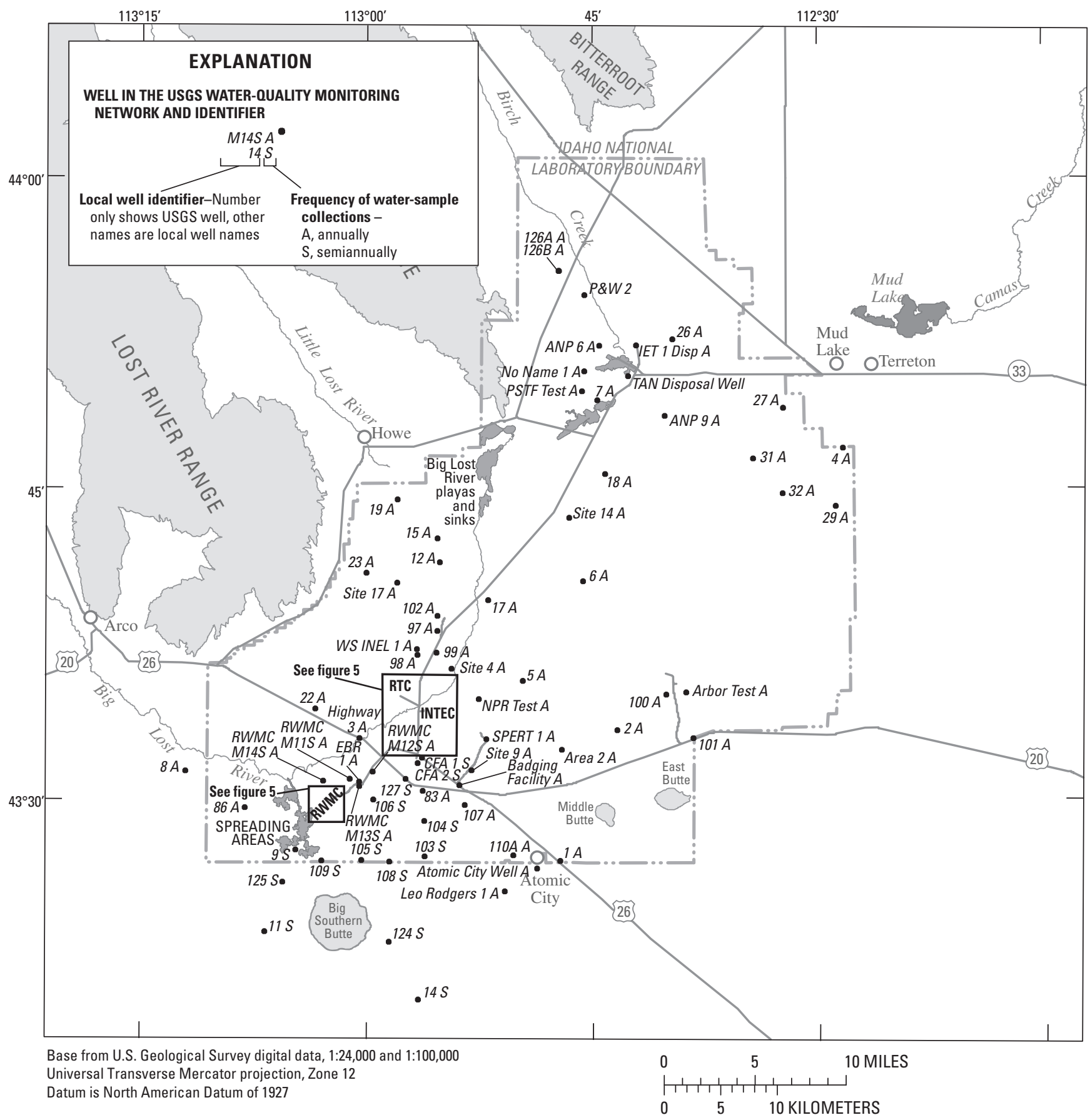

Figure 4. Location of wells in the U.S. Geological Survey water-quality monitoring network at the Idaho National Laboratory (INL) and vicinity, Idaho, and frequency of water-sample collections, as of December 2001. 


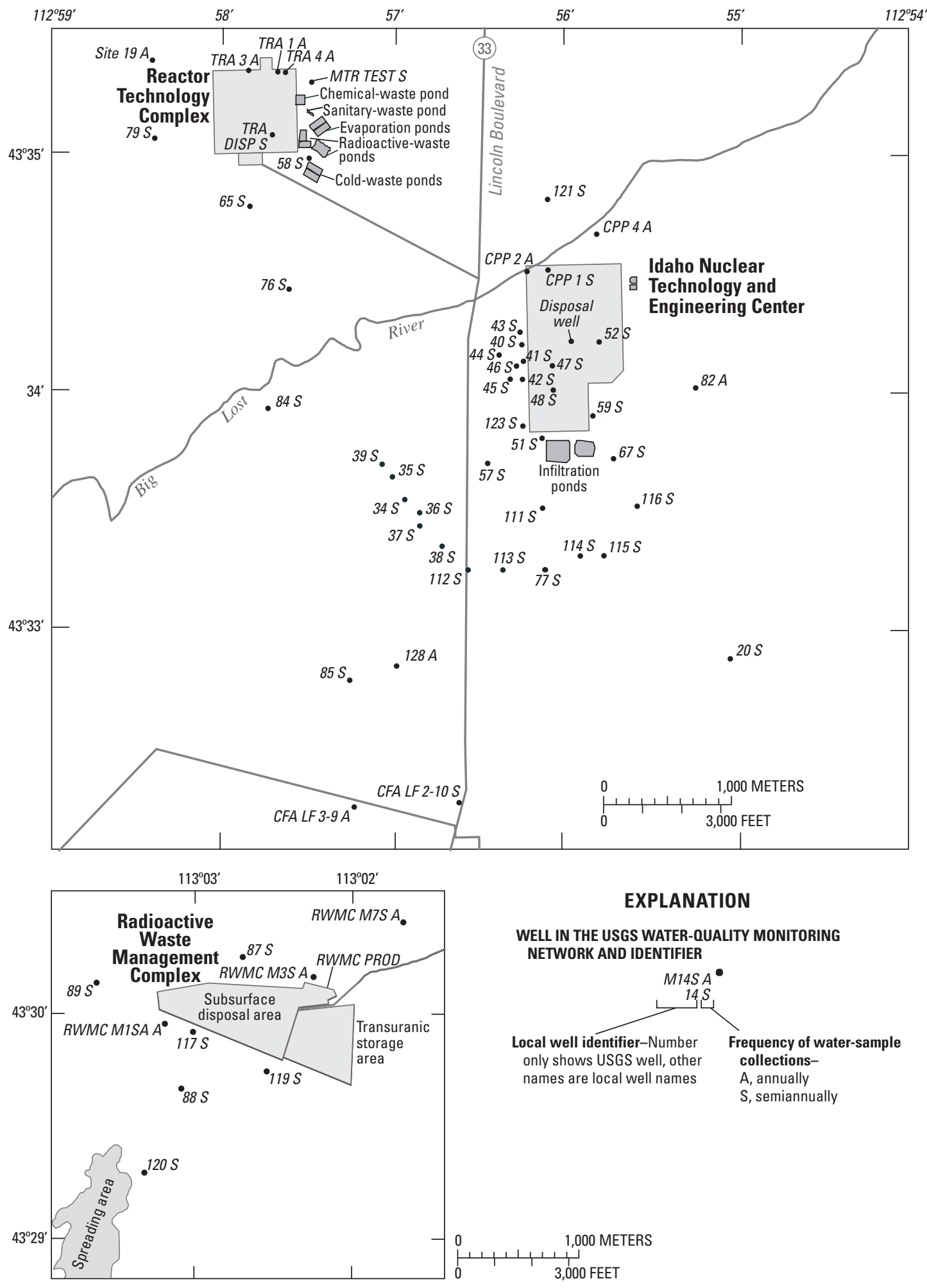

Figure 5. Location of wells in the U.S. Geological Survey water-quality monitoring network at the Reactor Technology Complex (RTC), Idaho Nuclear Technology and Engineering Center (INTEC), and Radioactive Waste Management Complex (RWMC) at the Idaho National Laboratory (INL) and vicinity, Idaho, and frequency of watersample collections, as of December 2001. 
Table 1. Location and construction of wells in the U.S. Geological Survey water-quality monitoring network and samplecollection method and frequency, Snake River Plain aquifer, Idaho National Laboratory, Idaho, as of December 2001.

[Well No.: Locations of wells are shown in figures 4 and $\underline{5}$. Sample-collection method: Pump, sampled from pumping well (pumping rate in gallons per minute); Tap, sampled from faucet. Sample-collection frequency: A, annual; S, semiannual. Abbreviations: USGS, U.S. Geological Survey]

\begin{tabular}{|c|c|c|c|c|c|}
\hline \multirow[b]{2}{*}{ Well No. } & \multirow[b]{2}{*}{ USGS site No. } & \multicolumn{2}{|c|}{ Well construction } & \multicolumn{2}{|c|}{ Sample collection } \\
\hline & & $\begin{array}{l}\text { Diameter } \\
\text { (inches) }\end{array}$ & $\begin{array}{c}\text { Depth } \\
\text { (feet) }\end{array}$ & Method & Frequency \\
\hline ANP 6 & 435152112443101 & 12 & 305 & Pump (45) & A \\
\hline ANP 9 & 434856112400001 & 12 & 322 & Pump (20) & A \\
\hline ARBOR TEST & 433509112384801 & 16 & 790 & Pump (20) & A \\
\hline AREA 2 & 433223112470201 & 16 & 877 & Pump (18) & A \\
\hline ATOMIC CITY & 432638112484101 & 8 & 639 & Tap & A \\
\hline BADGING FACILITY & 433042112535101 & 8 & 644 & Pump (35) & A \\
\hline CFA 1 & 433204112562001 & 16 & 685 & Pump $(1,000)$ & $\mathrm{S}$ \\
\hline CFA 2 & 433144112563501 & 20 & 681 & Pump $(1,400)$ & $\mathrm{S}$ \\
\hline CFA LF 2-10 & 433216112563301 & 6 & 765 & Pump (8.3) & $\mathrm{S}$ \\
\hline CFA LF 3-9 & 433216112571001 & 4 & 500 & Pump (7.5) & A \\
\hline CPP 1 & 433433112560201 & 20 & 585 & Pump $(3,000)$ & $\mathrm{S}$ \\
\hline CPP 2 & 433432112560801 & 16 & 605 & Pump $(3,000)$ & A \\
\hline CPP 4 & 433440112554401 & 16 & 700 & Pump (400) & A \\
\hline EBR 1 & 433051113002601 & 12 & 1,075 & Pump (25) & A \\
\hline HIGHWAY 3 & 433256113002501 & 8 & 750 & Tap & A \\
\hline IET 1 DISP & 435153112420501 & 20 & 324 & Pump (46) & A \\
\hline LEO RODGERS 1 & 432533112504901 & 20 & 702 & Pump (20) & A \\
\hline MTR TEST & 433520112572601 & 8 & 588 & Pump (26) & $\mathrm{S}$ \\
\hline NO NAME 1 & 435038112453401 & 12 & 550 & Pump (42) & A \\
\hline NPR TEST & 433449112523101 & 6 & 599 & Pump (28) & A \\
\hline PSTF TEST & 434941112454201 & 16 & 322 & Pump (44) & A \\
\hline P\&W 2 & 435419112453101 & 10 & 386 & Pump (35) & A \\
\hline RWMC M1SA & 432956113030901 & 6 & 638 & Pump (3.4) & A \\
\hline RWMC M3S & 433008113021801 & 6 & 633 & Pump (3.7) & A \\
\hline RWMC M7S & 433023113014801 & 6 & 638 & Pump (4.1) & A \\
\hline RWMC M11S & 433058113010401 & 6 & 607 & Pump (6) & A \\
\hline RWMC M12S & 433118112593401 & 6 & 560 & Pump (6) & A \\
\hline RWMC M13S & 433037113002701 & 6 & 632 & Pump (6) & A \\
\hline RWMC M14S & 433052113025001 & 6 & 633 & Pump (6) & A \\
\hline RWMC PROD & 433002113021701 & 16 & 683 & Pump (200) & $\mathrm{S}$ \\
\hline SITE 4 & 433617112542001 & 15 & 496 & Pump (500) & A \\
\hline SITE 9 & 433123112530101 & 10 & 1,057 & Pump (25) & A \\
\hline SITE14 & 434334112463101 & 10 & 717 & Pump (40) & A \\
\hline SITE 17 & 434027112575701 & 20 & 600 & Pump (25) & A \\
\hline SITE19 & 433522112582101 & 12 & 865 & Pump (30) & A \\
\hline SPERT-1 & 433252112520301 & 24 & 653 & Pump (400) & A \\
\hline TRA 1 & 433521112573801 & 20 & 600 & Pump $(3,400)$ & A \\
\hline TRA 3 & 433522112573501 & 20 & 602 & Pump $(3,800)$ & A \\
\hline TRA 4 & 433521112574201 & 20 & 975 & Pump $(2,000)$ & A \\
\hline TRA DISP & 433506112572301 & 12 & 1,267 & Pump (25) & $S$ \\
\hline USGS 1 & 432700112470801 & 6 & 636 & Pump (19) & A \\
\hline USGS 2 & 433320112432301 & 5 & 704 & Pump (16) & A \\
\hline USGS 4 & 434657112282201 & 6 & 553 & Pump (40) & A \\
\hline USGS 5 & 433543112493801 & 6 & 500 & Pump (5) & A \\
\hline USGS 6 & 434031112453701 & 6 & 620 & Pump (25) & A \\
\hline USGS 7 & 434915112443901 & 4 & 1,200 & Pump (45) & A \\
\hline USGS 8 & 433121113115801 & 6 & 812 & Pump (16) & A \\
\hline USGS 9 & 432740113044501 & 8 & 655 & Pump (19) & $\mathrm{S}$ \\
\hline USGS 11 & 432336113064201 & 12 & 704 & Pump (23) & $\mathrm{S}$ \\
\hline
\end{tabular}


Table 1. Location and construction of wells in the U.S. Geological Survey water-quality monitoring network and samplecollection method and frequency, Snake River Plain aquifer, Idaho National Laboratory, Idaho, as of December 2001._-Continued

[Well No.: Locations of wells are shown in figures 4 and $\underline{5}$. Sample-collection method: Pump, sampled from pumping well (pumping rate in gallons per minute); Tap, sampled from faucet. Sample-collection frequency: A, annual; S, semiannual. Abbreviations: USGS, U.S. Geological Survey]

\begin{tabular}{|c|c|c|c|c|c|}
\hline \multirow[b]{2}{*}{ Well No. } & \multirow[b]{2}{*}{ USGS site No. } & \multicolumn{2}{|c|}{ Well construction } & \multicolumn{2}{|c|}{ Sample collection } \\
\hline & & $\begin{array}{c}\text { Diameter } \\
\text { (inches) }\end{array}$ & $\begin{array}{l}\text { Depth } \\
\text { (feet) }\end{array}$ & Method & Frequency \\
\hline USGS 12 & 434126112550701 & 10 & 560 & Pump (32) & A \\
\hline USGS 14 & 432019112563201 & 6 & 751 & Pump (16) & $\mathrm{S}$ \\
\hline USGS 15 & 434234112551701 & 10 & 640 & Pump (40) & A \\
\hline USGS 17 & 433937112515401 & 6 & 498 & Pump (32) & $\mathrm{A}$ \\
\hline USGS 18 & 434540112440901 & 4 & 329 & Pump (30) & $\mathrm{A}$ \\
\hline USGS 19 & 434426112575701 & 6 & 405 & Pump (33) & $\mathrm{A}$ \\
\hline USGS 20 & 433253112545901 & 6 & 676 & Pump (30) & $\mathrm{S}$ \\
\hline USGS 22 & 433422113031701 & 6 & 657 & Pump (2.5) & A \\
\hline USGS 23 & 434055112595901 & 6 & 467 & Pump (25) & A \\
\hline USGS 26 & 435212112394001 & 8 & 266 & Pump (40) & A \\
\hline USGS 27 & 434851112321801 & 8 & 312 & Pump (20) & $\mathrm{A}$ \\
\hline USGS 29 & 434407112285101 & 6 & 422 & Pump (32) & $\mathrm{A}$ \\
\hline USGS 31 & 434625112342101 & 8 & 428 & Pump (40) & A \\
\hline USGS 32 & 434444112322101 & 6 & 392 & Pump (28) & A \\
\hline USGS 34 & 433334112565501 & 10 & 700 & Pump (30) & $\mathrm{S}$ \\
\hline USGS 35 & 433339112565801 & 7 & 578 & Pump (25) & $\mathrm{S}$ \\
\hline USGS 36 & 433330112565201 & 6 & 567 & Pump (25) & $\mathrm{S}$ \\
\hline USGS 37 & 433326112564801 & 8 & 573 & Pump (25) & $\mathrm{S}$ \\
\hline USGS 38 & 433322112564301 & 8 & 729 & Pump (4) & $\mathrm{S}$ \\
\hline USGS 39 & 433343112570001 & 6 & 572 & Pump (25) & $\mathrm{S}$ \\
\hline USGS 40 & 433411112561101 & 6 & 483 & Pump (8) & $\mathrm{S}$ \\
\hline USGS 41 & 433409112561301 & 6 & 674 & Pump (25) & $\mathrm{S}$ \\
\hline USGS 42 & 433404112561301 & 6 & 678 & Pump (25) & $\mathrm{S}$ \\
\hline USGS 43 & 433415112561501 & 6 & 676 & Pump (6) & $\mathrm{S}$ \\
\hline USGS 44 & 433409112562101 & 6 & 650 & Pump (25) & $\mathrm{S}$ \\
\hline USGS 45 & 433402112561801 & 6 & 651 & Pump (25) & $\mathrm{S}$ \\
\hline USGS 46 & 433407112561501 & 6 & 651 & Pump (25) & $\mathrm{S}$ \\
\hline USGS 47 & 433407112560301 & 6 & 652 & Pump (8) & $\mathrm{S}$ \\
\hline USGS 48 & 433401112560301 & 6 & 750 & Pump (29) & $\mathrm{S}$ \\
\hline USGS 51 & 433350112560601 & 6 & 659 & Pump (4) & $\mathrm{S}$ \\
\hline USGS 52 & 433414112554201 & 6 & 650 & Pump (30) & $\mathrm{S}$ \\
\hline USGS 57 & 433344112562601 & 6 & 732 & Pump (30) & $\mathrm{S}$ \\
\hline USGS 58 & 433500112572502 & 6 & 503 & Pump (26) & $\mathrm{S}$ \\
\hline USGS 59 & 433354112554701 & 6 & 657 & Pump (1) & $\mathrm{S}$ \\
\hline USGS 65 & 433447112574501 & 6 & 498 & Pump (8) & $\mathrm{S}$ \\
\hline USGS 67 & 433344112554101 & 6 & 698 & Pump (8) & $\mathrm{S}$ \\
\hline USGS 76 & 433425112573201 & 6 & 718 & Pump (29) & $\mathrm{S}$ \\
\hline USGS 77 & 433315112560301 & 6 & 610 & Pump (25) & $\mathrm{S}$ \\
\hline USGS 79 & 433505112581901 & 6 & 702 & Pump (30) & $\mathrm{S}$ \\
\hline USGS 82 & 433401112551001 & 8 & 700 & Pump (25) & $\mathrm{S}$ \\
\hline USGS 83 & 433023112561501 & 6 & 752 & Pump (28) & $\mathrm{A}$ \\
\hline USGS 84 & 433356112574201 & 6 & 505 & Pump (5) & $\mathrm{S}$ \\
\hline USGS 85 & 433246112571201 & 6 & 637 & Pump (23) & $\mathrm{S}$ \\
\hline USGS 86 & 432935113080001 & 8 & 691 & Pump (19) & A \\
\hline USGS 87 & 433013113024201 & 6 & 673 & Pump (2) & $\mathrm{S}$ \\
\hline USGS 88 & 432940113030201 & 6 & 662 & Pump (2) & $\mathrm{S}$ \\
\hline USGS 89 & 433005113032801 & 6 & 646 & Pump (5) & $\mathrm{S}$ \\
\hline USGS 97 & 433807112551501 & 4 & 510 & Pump (27) & $\mathrm{A}$ \\
\hline USGS 98 & 433657112563601 & 6 & 505 & Pump (25) & A \\
\hline USGS 99 & 433705112552101 & 6 & 450 & Pump (25) & A \\
\hline
\end{tabular}


Table 1. Location and construction of wells in the U.S. Geological Survey water-quality monitoring network and samplecollection method and frequency, Snake River Plain aquifer, Idaho National Laboratory, Idaho, as of December 2001.—Continued

[Well No.: Locations of wells are shown in figures 4 and $\underline{5}$. Sample-collection method: Pump, sampled from pumping well (pumping rate in gallons per minute); Tap, sampled from faucet. Sample-collection frequency: A, annual; S, semiannual. Abbreviations: USGS, U.S. Geological Survey]

\begin{tabular}{|c|c|c|c|c|c|}
\hline \multirow[b]{2}{*}{ Well No. } & \multirow[b]{2}{*}{ USGS site No. } & \multicolumn{2}{|c|}{ Well construction } & \multicolumn{2}{|c|}{ Sample collection } \\
\hline & & $\begin{array}{c}\text { Diameter } \\
\text { (inches) }\end{array}$ & $\begin{array}{l}\text { Depth } \\
\text { (feet) }\end{array}$ & Method & Frequency \\
\hline USGS 100 & 433503112400701 & 6 & 750 & Pump (10) & $\mathrm{A}$ \\
\hline USGS 101 & 433255112381801 & 6 & 865 & Pump (13) & A \\
\hline USGS 102 & 433853112551601 & 6 & 760 & Pump (29) & A \\
\hline USGS 103 & 432714112560701 & 8 & 445 & Pump (21) & $\mathrm{S}$ \\
\hline USGS 104 & 432856112560801 & 8 & 700 & Pump (26) & $\mathrm{S}$ \\
\hline USGS 105 & 432703113001801 & 8 & 800 & Pump (24) & $\mathrm{S}$ \\
\hline USGS 106 & 432959112593101 & 8 & 760 & Pump (24) & $\mathrm{S}$ \\
\hline USGS 107 & 432942112532801 & 8 & 690 & Pump (30) & $\mathrm{A}$ \\
\hline USGS 108 & 432659112582601 & 8 & 760 & Pump (24) & $\mathrm{S}$ \\
\hline USGS 109 & 432701113025601 & 6 & 800 & Pump (22) & $\mathrm{S}$ \\
\hline USGS 110A & 432717112501502 & 10 & 644 & Pump (24) & $\mathrm{A}$ \\
\hline USGS 111 & 433331112560501 & 8 & 595 & Pump (15) & $\mathrm{S}$ \\
\hline USGS 112 & 433314112563001 & 8 & 563 & Pump (30) & $\mathrm{S}$ \\
\hline USGS 113 & 433314112561801 & 6 & 564 & Pump (25) & $\mathrm{S}$ \\
\hline USGS 114 & 433318112555001 & 6 & 562 & Pump (10) & $\mathrm{S}$ \\
\hline USGS 115 & 433320112554101 & 6 & 581 & Pump (5) & $\mathrm{S}$ \\
\hline USGS 116 & 433331112553201 & 6 & 580 & Pump (20) & $\mathrm{S}$ \\
\hline USGS 117 & 432955113025901 & 8 & 655 & Pump (12) & $\mathrm{S}$ \\
\hline USGS 119 & 432945113023401 & 8 & 705 & Pump (3) & $\mathrm{S}$ \\
\hline USGS 120 & 432919113031501 & 8 & 705 & Pump (27) & $\mathrm{S}$ \\
\hline USGS 121 & 433450112560301 & 8 & 475 & Pump (8) & $\mathrm{S}$ \\
\hline USGS 123 & 433352112561401 & 8 & 481 & Pump (3) & $\mathrm{S}$ \\
\hline USGS 124 & 432307112583101 & 4 & 800 & Pump (19) & $\mathrm{S}$ \\
\hline USGS 125 & 432602113052801 & 10 & 760 & Pump (21) & $\mathrm{S}$ \\
\hline USGS 126A & 435529112471301 & 5 & 648 & Pump & A \\
\hline USGS 126B & 435529112471401 & 10 & 452 & Pump & A \\
\hline USGS 127 & 433058112572201 & 10 & 596 & Pump (25) & $\mathrm{S}$ \\
\hline USGS 128 & 433250112565601 & 4.5 & 618 & Pump (23) & A \\
\hline WS INEL1 & 433716112563601 & 8 & 595 & Pump (30) & A \\
\hline
\end{tabular}

\section{Waste-Disposal Sites at the Idaho National Laboratory}

Wastewater disposal sites at INL facilities have been the principal sources of radioactive- and chemical-waste constituents in water from the Snake River Plain aquifer at and near the INL. In the past, wastewater disposal sites have included infiltration ponds and ditches, evaporation ponds, drain fields, and disposal wells. Solid and liquid wastes buried at the RWMC (fig. 1) also are sources of some constituents in ground water.

Radioactive- and chemical-waste-disposal data are collected by contractors at each INL facility. Historical radioactive-waste-disposal data presented in this report were obtained from a series of radioactive-waste-management information reports (French and others, 1997b; French and Taylor, 1998, and French and others, 1999b). Chemical-waste- disposal data were obtained from a series of nonradiologicalwaste-management information reports (French and others, 1997a; 1998; 1999a). Since 1999, there has been no formal program in place to compile annual amounts of constituents discharged at each facility (Richard Kauffman, U.S.

Department of Energy, oral commun., 2005), however, the INEEL Site Environmental Reports (Stoller Corp., 2002a, $2002 \mathrm{~b}$, and 2002c) provide some radioactive waste disposal data for 1999-2001. Effluent monitoring and wastewater discharge raw data for some INL facilities were provided to the author by DOE contractor personnel (Teresa Meachum, CH2M-WG Idaho, LLC, written commun., 2005), however compilation of those data was beyond the scope of this report. Therefore, amounts and types of most radioactiveand chemical-wastes discharged at the various facilities for 1999-2001 are not presented in this report. 


\section{Reactor Technology Complex}

Since 1959, low-level radioactive, chemical, and sanitary wastewater has been discharged to infiltration and lined evaporation ponds. Nonradioactive cooling-tower wastewater was discharged to radioactive-waste infiltration ponds from 1952 to 1964 , to the Snake River Plain aquifer through a 1,267-ft-deep disposal well (TRA DISP, fig. 3) from 1964 until March 1982, and into two cold-waste infiltration ponds from 1982 to the present.

In 1976, the DOE contractor at the RTC began a three-phase program to reduce radioactivity in wastewater. The first phase ran from 1976 to 1980 and the second phase ran from 1981 to 1987 . The contractor finished the final phase of the program in 1993. The volume of radioactive wastewater and total number of Curies (Ci) of radioactivity discharged at the RTC decreased because of this program. During 1977-78, the average number of Curies discharged to the RTC radioactive-waste infiltration ponds was about 1,300 Ci/yr (Barraclough and others, 1981); during 1992-95, about $430 \mathrm{Ci}$ of tritium was discharged to the RTC radioactive-waste infiltration ponds. During 1992-95, tritium accounted for about 96 percent of radioactivity in wastewater discharged at the RTC (Bartholomay and others, 1997).

In August 1993, two lined evaporation ponds replaced the radioactive-waste infiltration ponds (B.R. Orr, U.S. Geological Survey, oral commun., 1996). The evaporation ponds may prevent radioactive wastewater from entering the aquifer.

The average annual discharge to the radioactive-waste infiltration and evaporation ponds (ig. 3) was about $116 \mathrm{Mgal}$ during 1960-98. The volume of wastewater and the amount of tritium discharged to the radioactive-waste and evaporation ponds during this period are shown in figure 6. During 2000-01, effluent waste disposal to the evaporation ponds averaged about $5 \mathrm{Mgal}$ (Richard Kauffman, U.S. Department of Energy, written commun., 2005), much less than the longterm average.

During 1974-79, about 10 percent of the radioactivity in wastewater discharged was attributed to tritium; most of the rest consisted of radionuclides with half-lives on the order of several weeks, as well as small amounts of strontium-90, cesium-137, and cobalt-60 (Barraclough and others, 1981). In 1980, about 50 percent was attributed to tritium; and during 1981-85, about 90 percent was attributed to tritium (Pittman and others, 1988, p. 22). Since 1986, about 97 percent of the radioactivity in wastewater discharged at the RTC has been attributed to tritium (fig. 6).

A chemical-waste infiltration pond was used for disposal of chemical wastewater from an ion-exchange system at the RTC (fig. 3) from 1962 to 1999. The average annual discharge to this pond was about 17.5 Mgal for the period 1962-98 (Bartholomay and others, 2000). The average annual discharge for 1996-98 was 5.8 Mgal, 33 percent of the long-term average (Bartholomay and others, 2000). Sulfate and sodium hydrate were the predominant constituents in the chemical wastewater. The sodium hydrate consists of a 50 percent sodium hydroxide solution (Bartholomay and others, 2000). During 1996-98, average annual amounts of about 210,280 $\mathrm{lb}$ of sulfate and $98,800 \mathrm{lb}$ of sodium hydrate were discharged to the chemical-waste infiltration pond. Additionally, about 11,100 lb of sodium ion was discharged in October 1996 (French and others, 1997a). Average annual concentrations of sulfate and sodium hydrate in the wastewater were about 4,300 and 2,000 mg/L, respectively (Bartholomay and others, 2000). In 1999, the chemical-waste infiltration pond was closed and covered with a protective cap (Stoller Corp., 2002a).

The TRA disposal well, which currently is used as an observation well, was used from 1964 to March 1982 to inject nonradioactive wastewater from cooling-tower operations at the RTC into the Snake River Plain aquifer. Since March 1982, this wastewater has been discharged to two cold-waste infiltration ponds (fig. 3). The average annual discharge to the well and the infiltration ponds was about $226 \mathrm{Mgal}$ during 1964-95 and about 181 Mgal during 1996-98 (Bartholomay and others, 2000). This wastewater contained an average annual amount of about 402,000 lb of sulfate and 94,000 lb of other chemicals during 1996-98 (Bartholomay and others, 2000).

Sewage effluent discharged to sanitary-waste infiltration ponds (fig. 3) at the RTC was about $28 \mathrm{Mgal} / \mathrm{yr}$ during 1996-98 (Bartholomay and others, 2000), about $17 \mathrm{Mgal}$ in 2000, and about $52 \mathrm{Mgal}$ in 2001 (Richard Kauffman, U.S. Department of Energy, written commun., 2005). In 1989, the sewage effluent contained about $1,070 \mathrm{lb}$ of chloride and $1,550 \mathrm{lb}$ of hypochlorite. Chloride and hypochlorite were not reported as part of the sewage effluent after February 1990 (Bartholomay and others, 2000).

\section{Idaho Nuclear Technology and Engineering Center}

From 1952 to February 1984, the INTEC discharged most of its low-level radioactive, chemical, and sanitary wastewater into the Snake River Plain aquifer through a 600-ft-deep disposal well (fig. 5). The average annual discharge of wastewater to the well was about $363 \mathrm{Mgal}$ (Pittman and others, 1988, p. 24). Two infiltration ponds were used for wastewater disposal during 1999-2001 (fig. 3). The first pond was completed in February 1984 and the second pond was completed in October 1985. The annual discharge to the disposal well and ponds ranged from $260 \mathrm{Mgal}$ in 1963 to $665 \mathrm{Mgal}$ in 1993. The discharge to the ponds during 2001 was about 544 Mgal (Stoller Corp., 2002c, p 5-9); data for 1999 and 2000 are not available. The volume of wastewater discharged to the disposal well and infiltration ponds during 1962-2001 is shown in figure 7. 

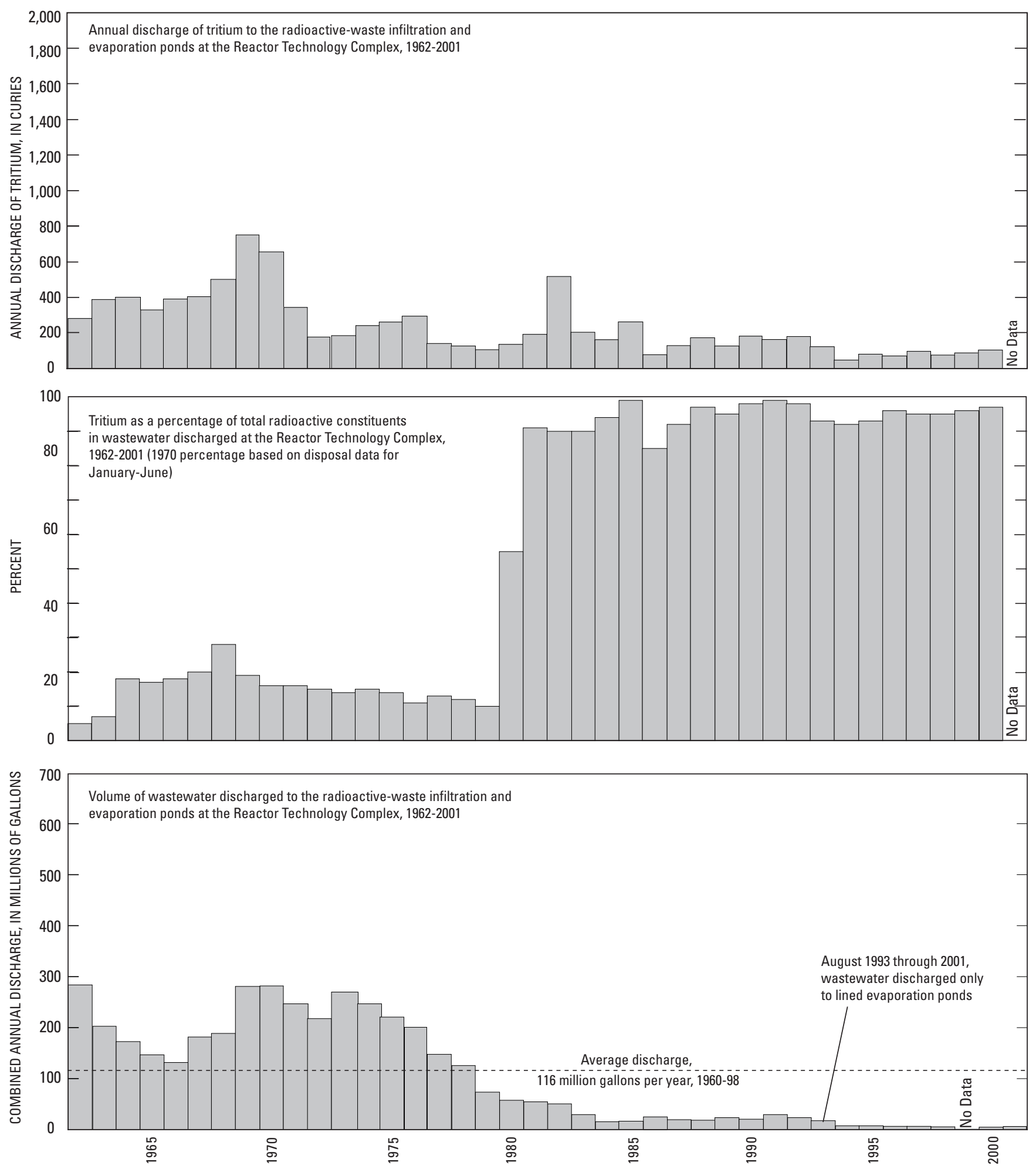

Figure 6. Amount of tritium discharged, tritium as a percentage of total radioactive constituents in wastewater discharged, and volume of wastewater discharged to the radioactive-waste infiltration and evaporation ponds at the Reactor Technology Complex (RTC), Idaho, 1962-2001. 

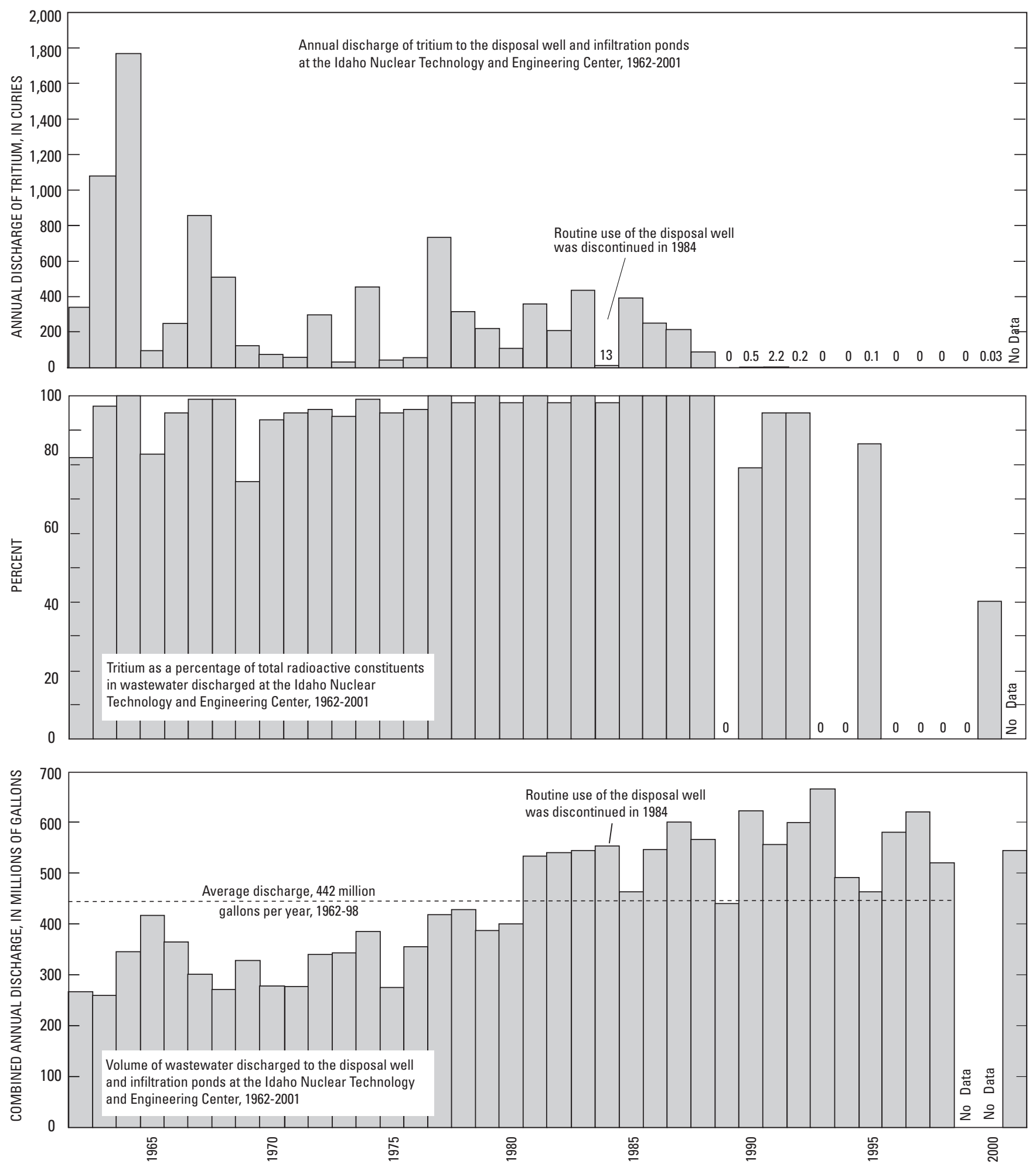

Figure 7. Amount of tritium discharged, tritium as a percentage of total radioactive constituents in wastewater discharged, and volume of wastewater discharged to the disposal well and infiltration ponds at the Idaho Nuclear Technology and Engineering Center (INTEC), Idaho, 1962-2001. 
Most of the radioactivity in wastewater discharged to the infiltration ponds at the INTEC is attributed to tritium. Tritium has accounted for more than 90 percent of the radioactivity in wastewater discharged at the INTEC since 1970 (fig. 7). During 1986-88, a total of $556 \mathrm{Ci}$ of tritium was discharged at the INTEC and the average annual amount was $185 \mathrm{Ci}$ (Orr and Cecil, 1991, p. 20). During 1990-91, only 2.7 Ci of tritium was discharged; during 1992 and 1995 only about $0.3 \mathrm{Ci}$ was discharged; no tritium was discharged during 1989, 1993, 1994, and 1996-99; and 0.03 Ci was discharged during 2000 (fig. 7). No data are available for the amount of tritium discharged during 2001.

During 1996-98, chloride, fluoride, nitrate, sodium, and sulfate were the predominant chemical constituents in wastewater discharged to the INTEC infiltration ponds. Average annual amounts of about 1,166,000 lb of chloride; $1,070 \mathrm{lb}$ of fluoride; $86,700 \mathrm{lb}$ of nitrate; 708,000 lb of sodium, and 146,000 lb of sulfate were in wastewater discharged at the INTEC. Data for predominant constituents and amounts in wastewater discharged during 1999-2001 have not been compiled.

\section{Radioactive Waste Management Complex}

Solid and liquid radioactive and chemical wastes have been buried in trenches and pits at the Subsurface Disposal Area (SDA) at the RWMC (fig. 3) since 1952. These constituents include transuranic wastes, other radiochemical and inorganic chemical constituents, and organic compounds. The transuranic wastes were buried in trenches until 1970, and stored above ground at the RWMC after 1970. Only low-level mixed waste has been buried at the RWMC since 1970. Before 1970, little or no sediment was retained between the excavation bottoms and the underlying basalt. Since 1970, a layer of sediment has been retained in excavations to inhibit downward migration of waste constituents.

About 17,100 Ci of plutonium-238, 64,900 Ci of plutonium-239, 17,100 Ci of plutonium-240, and 183,000 Ci of americium-241 were buried in the SDA during 1952-99 (Holdren and others, 2002, table 4-1). An estimated 88,400 gal of organic waste was buried before 1970 (Mann and Knobel, 1987 , p. 1). These buried wastes included about 24,400 gal of carbon tetrachloride; 39,000 gal of lubricating oil; and about 25,000 gal of other organic compounds, including trichloroethane, trichloroethylene, perchloroethylene, toluene, and benzene.

\section{Test Area North}

From 1953 to 1972, low-level radioactive, chemical, and sanitary wastewater was discharged at TAN (ig. 1) into the Snake River Plain aquifer through a 310-ft-deep disposal well (TAN Disposal Well, fig. 4). In 1972, the disposal well was replaced by a 35 -acre infiltration pond. No records are available as to the amount of radioactivity in wastewater that was discharged at TAN before 1959. During 1959-93, a total of about $61 \mathrm{Ci}$ of radioactivity in wastewater was discharged to the disposal well and infiltration pond. Of this amount, about $20 \mathrm{Ci}$ was discharged to the disposal well in 1968 and 1969 in response to problems with an evaporator used to reduce the volume of liquid waste (Energy Research and Development Administration, 1977, p. II-110, II-111). No radioactive wastewater has been discharged since 1993 (Bartholomay and others, 2000).

An average of about $6.6 \mathrm{Mgal} / \mathrm{yr}$ of chemical wastewater was discharged to the infiltration pond at the Technical Support Facility during 1996-98 (Bartholomay and others, 2000). The predominant constituents were chloride and sodium. Average annual amounts of 6,900 lb of chloride and $4,500 \mathrm{lb}$ of sodium were discharged. The average annual amount of all other chemical constituents in the wastewater was about $760 \mathrm{lb}$ (Bartholomay and others, 2000). During 1999-2001, about 28.5 Mgal of wastewater was discharged (Teresa Meachum, CH2M-WG Idaho, LLC, written commun., 2005). Data for total amounts of individual constituents disposed in wastewater for 1999-2001 are unavailable.

\section{Central Facilities Area}

A total of about $65 \mathrm{Ci}$ of radioactivity in about 1,500 Mgal of wastewater was discharged to the sewage-plant tile drain field at the CFA (fig. 1) during 1952-93. Most of the radioactive wastes discharged to this drain field were from aquifer water pumped from well CFA 1 (fig. 4), which obtains water from within the INTEC contaminant plume in the Snake River Plain aquifer. Most of the radioactivity in wastewater discharged at the CFA is attributed to tritium. During 1993-98, no radioactivity was recorded in wastewater discharged at the CFA (Bartholomay and others, 2000).

An average of about 42.1 Mgal/yr of wastewater was discharged to a pond at CFA and a computerized central pivot system discharged about $13.6 \mathrm{Mgal} / \mathrm{yr}$ to native desert rangeland during 1999-2001 (Stoller Corp., 2002c; Teresa Meachum, CH2M-WG Idaho, LLC, written commun., 2005). Chloride and sodium were the predominant chemical constituents in the wastewater during 1996-98. Average annual amounts of about 7,800 lb of chloride and 5,300 lb of sodium were discharged during 1996-98. The average annual amount of all other constituents in the wastewater was about 6,300 lb; about 5,400 lb was from disposal of janitorial supplies (Bartholomay and others, 2000). Data for total amounts of individual constituents disposed in wastewater for 1999-2001 are unavailable. 


\section{Hydrologic Conditions}

The Snake River Plain aquifer is one of the most productive aquifers in the United States (U.S. Geological Survey, 1985, p. 193). The aquifer consists of a thick sequence of basalts and sedimentary interbeds filling a large, arcuate, structural basin in southeastern Idaho (fig. 1).

Recharge to the Snake River Plain aquifer is principally from infiltration of applied irrigation water, infiltration of streamflow, ground-water inflow from adjoining mountain drainage basins, and infiltration of precipitation.

\section{Surface Water}

The Big Lost River drains more than $1,400 \mathrm{mi}^{2}$ of mountainous area that includes parts of the Lost River Range and Pioneer Mountains west of the INL (fig. 1). Flow in the Big Lost River infiltrates to the Snake River Plain aquifer along its channel and at sinks and playas at the river's terminus. To avoid flooding at the INL facilities, excess runoff has been diverted since 1965 to spreading areas in the southwestern part of the INL (Bennett, 1990, p. 15), where much of the water rapidly infiltrates to the aquifer. Other surface drainages that provide recharge to the Snake River Plain aquifer at the INL include Birch Creek, Little Lost River, and Camas Creek (fig. 1).

The average streamflow at gaging station 13127000, Big Lost River below Mackay Reservoir (fig. 1) for complete water years from 1904 to 2001 was 223,800 acre-ft/yr (O'Dell and others, 2002, p. 193) (fig. 8). Streamflow at surface-water gaging stations at and downstream of gaging station 13127000 (fig. 1) for water years 1999-2001 are given in table 2 and figure 8.

Recharge to the Snake River Plain aquifer downstream of Arco is substantial during wet years because of infiltration of streamflow from the Big Lost River channel, diversion areas, sinks, and playas. For example, measured infiltration losses at various discharges measured during 1951-85 ranged from $1\left(\mathrm{ft}^{3} / \mathrm{s}\right) / \mathrm{mi}$ in the river channel to $28\left(\mathrm{ft}^{3} / \mathrm{s}\right) / \mathrm{mi}$ in the sinks (Bennett, 1990, p. 24-26). Bennett (1990) considered streamflow losses to evapotranspiration minor compared with infiltration losses. However, infiltration can be zero in years when there is little or no flow in the Big Lost River channel as was the case in 2001 at and downstream of gaging station 13132500 (table 2).

\section{Ground Water}

Water in the Snake River Plain aquifer moves principally through interflow and fracture zones in the basalt. A significant proportion of the ground water moves through the upper 200 to $800 \mathrm{ft}$ of basaltic rocks (Mann, 1986, p. 21).
Table 2. Average annual streamflow at gaging stations along the Big Lost River, Idaho, water years 1999-2001.

[Gaging station: Location of stations are shown in figure 1. Streamflow data: Data for 1999 from Brennan and others (2000), for 2000, from Brennan and others (2001), for 2001 from O'Dell and others (2002). Abbreviations: INL, Idaho National Laboratory; WY, water year]

\begin{tabular}{cccr}
\hline \multirow{2}{*}{ Gaging station } & \multicolumn{3}{c}{ Streamflow (in acre-feet) } \\
\cline { 2 - 4 } & WY 1999 & WY 2000 & WY 2001 \\
\hline $\begin{array}{c}\text { 13127000_Big Lost River } \\
\text { below Mackay Reservoir }\end{array}$ & 274,900 & 170,600 & 133,300 \\
$\begin{array}{l}\text { 13132500-Big Lost River } \\
\text { near Arco }\end{array}$ & 116,100 & 29,950 & 205 \\
$\begin{array}{l}\text { 13132513-INL Diversion at } \\
\text { head, near Arco }\end{array}$ & 22,290 & 0 & 0 \\
$\begin{array}{l}\text { 13132520-Big Lost River } \\
\text { below the INL Diversion, } \\
\text { near Arco }\end{array}$ & 85,970 & 21,600 & 0 \\
$\begin{array}{l}\text { 13132565-Big Lost River } \\
\text { above Big Lost River Sinks, } \\
\text { near Howe }\end{array}$ & 55,040 & & \\
\hline
\end{tabular}

Ackerman (1991, p. 30) and Bartholomay and others (2000, p. 15) reported a range of transmissivity of basalt in the upper part of the aquifer of 1.1 to $760,000 \mathrm{ft}^{2} / \mathrm{d}$. Anderson and others (1999) reported a range of hydraulic conductivity at the INL of 0.01 to $32,000 \mathrm{ft} / \mathrm{d}$. The hydraulic conductivity of rocks underlying the aquifer is from 0.002 to $0.03 \mathrm{ft} / \mathrm{d}$, several orders of magnitude smaller (Mann, 1986, p. 21). The effective base of the Snake River Plain aquifer probably ranges from about 815 to $1,710 \mathrm{ft}$ below land surface in the western half of the INL (Anderson and others, 1996, table 3).

Depth to water in wells completed in the Snake River Plain aquifer ranges from about $200 \mathrm{ft}$ in the northern part of the INL to more than $900 \mathrm{ft}$ in the southeastern part. During March-May 2001, the altitude of the water table was about $4,600 \mathrm{ft}$ in the northern part of the INL (fig. 9) and about $4,420 \mathrm{ft}$ in the southwestern part. Water flowed southward and southwestward beneath the INL (fig. 9) at an average hydraulic gradient of about $4 \mathrm{ft} / \mathrm{mi}$.

From March-May 1998 to March-May 2001, water levels in wells in the northern and west-central part of the INL generally rose; rises ranged from about 1 to $3 \mathrm{ft}$ (fig. 10). These rises may be attributed to lag time for water infiltrating the Big Lost River channel and sinks during 2000-01.

During the same period, water-level declines in wells in the southwestern part of the INL near the spreading areas ranged from about 1 to $4 \mathrm{ft}$ (fig. 10). These declines are attributed to lack of infiltration in the spreading areas during 2000 and 2001. 
Water levels monitored in wells USGS 12, USGS 17, and USGS 23 (fig. 2), and USGS 20 (fig. 3) show long-term waterlevel changes in the Snake River Plain aquifer at different locations at the INL in response to infiltration of streamflow (fig. 11). Long-term water-level fluctuations have ranged from about $11 \mathrm{ft}$ in well USGS 20 to about $27 \mathrm{ft}$ in well USGS 12. Water levels in these wells declined from 1999 to 2001 because of decreased infiltration of streamflow in the Big Lost River, and an overall decrease in recharge to the Snake River Plain aquifer.
Ground water moves southwestward from the INL and eventually is discharged to springs along the Snake River near Twin Falls, 100 mi southwest of the INL. Discharge from the springs estimated by methods given by Kjelstrom (1995) was about 4.26 million acre-ft/yr for the 2001 water year (Tom Brennan, U.S. Geological Survey, written commun., 2002). Historically, the discharge to these springs has ranged from 2.97 million acre-ft/yr in 1904 to 4.94 million acre-ft/yr in 1951 (Daniel J. Ackerman, U.S. Geological Survey, written commun., 2005).
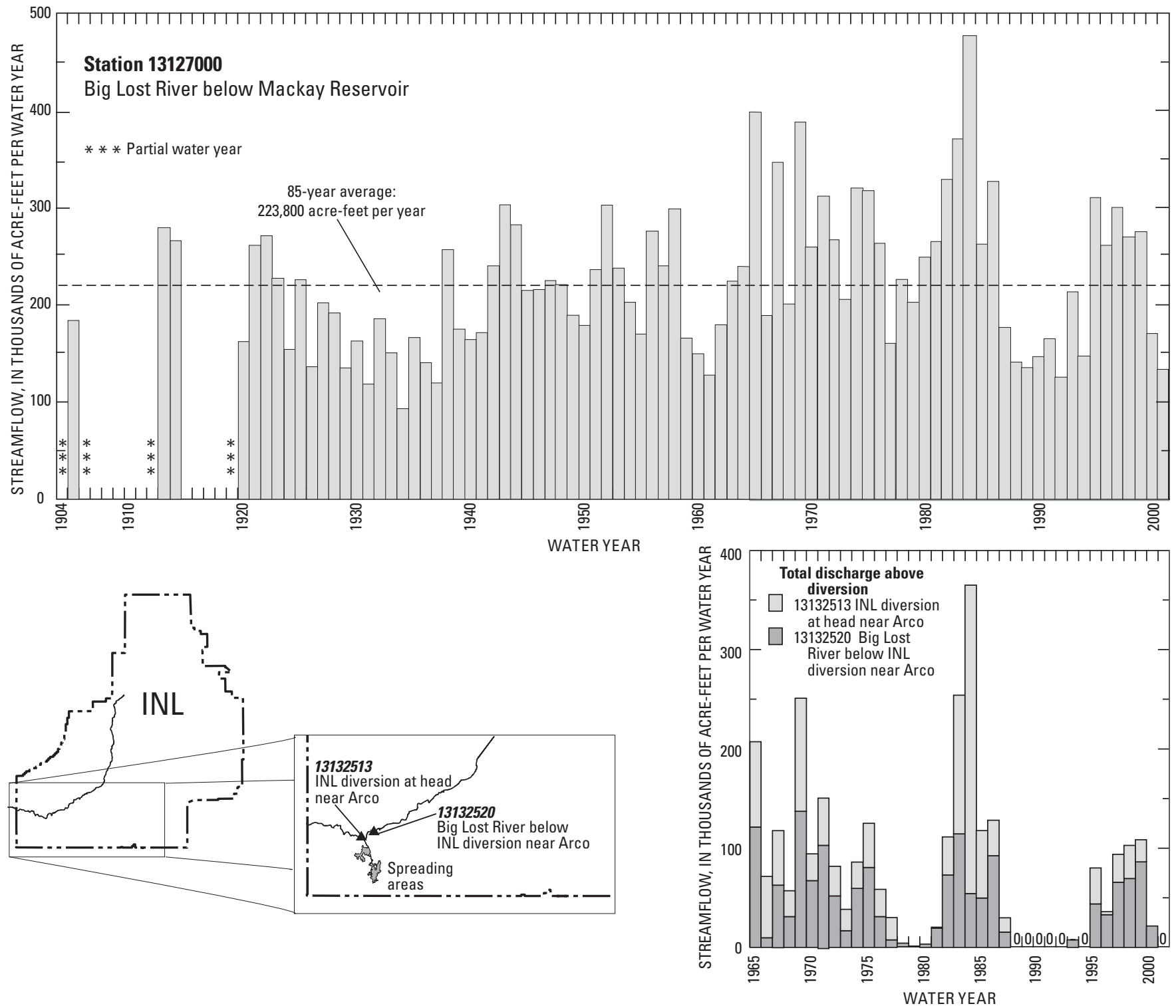

Figure 8. Discharge at gaging stations along the Big Lost River: Big Lost River below Mackay Reservoir, water years 1904-06, 1912-14, and 1919-2001; Big Lost River below the Idaho National Laboratory (INL) diversion near Arco, and the INL diversion at head near Arco, Idaho, water years 1965-2001. 


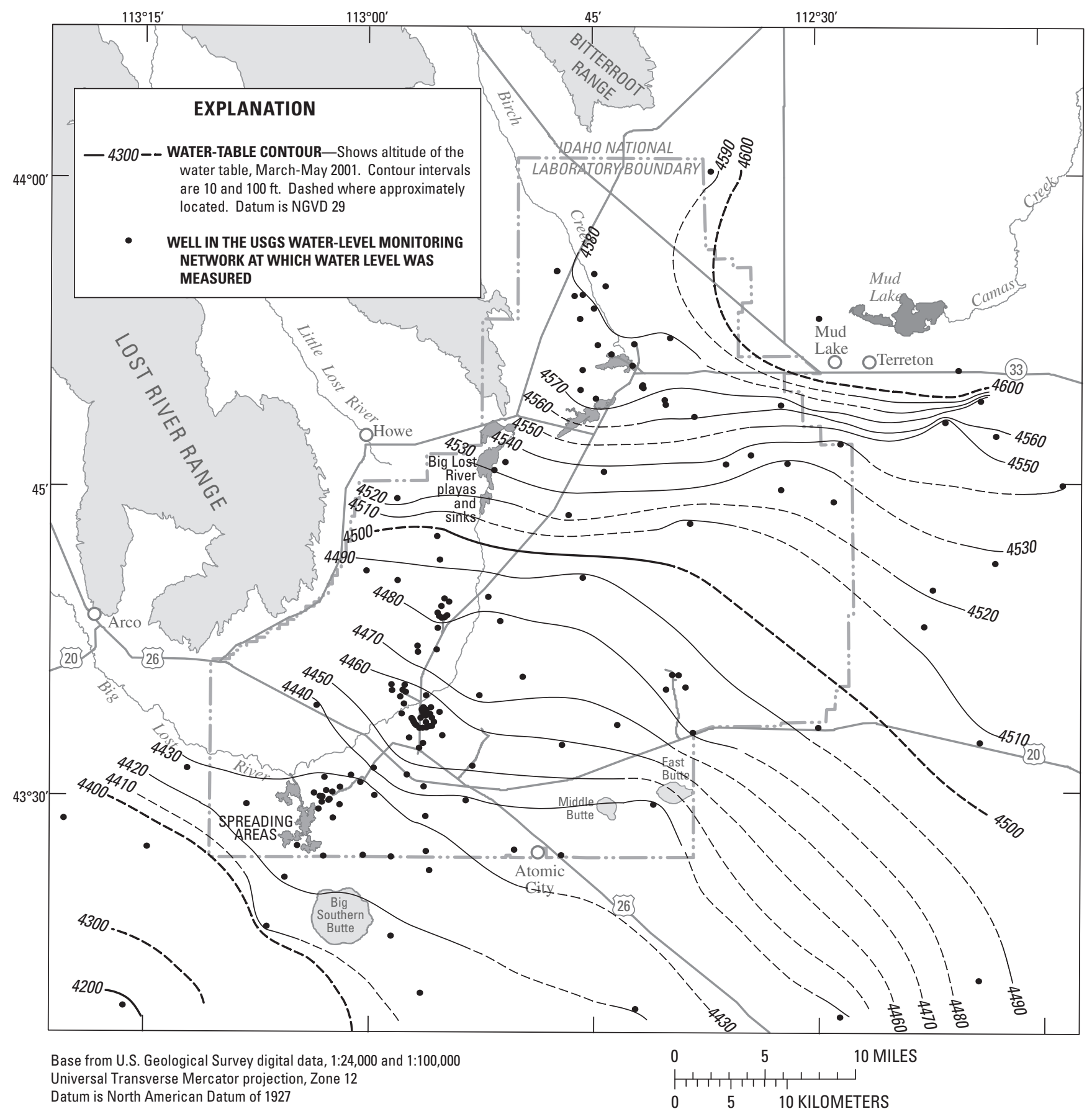

Figure 9. Altitude of the water table in the Snake River Plain aquifer in the vicinity of the Idaho National Laboratory (INL), Idaho, March-May 2001. 


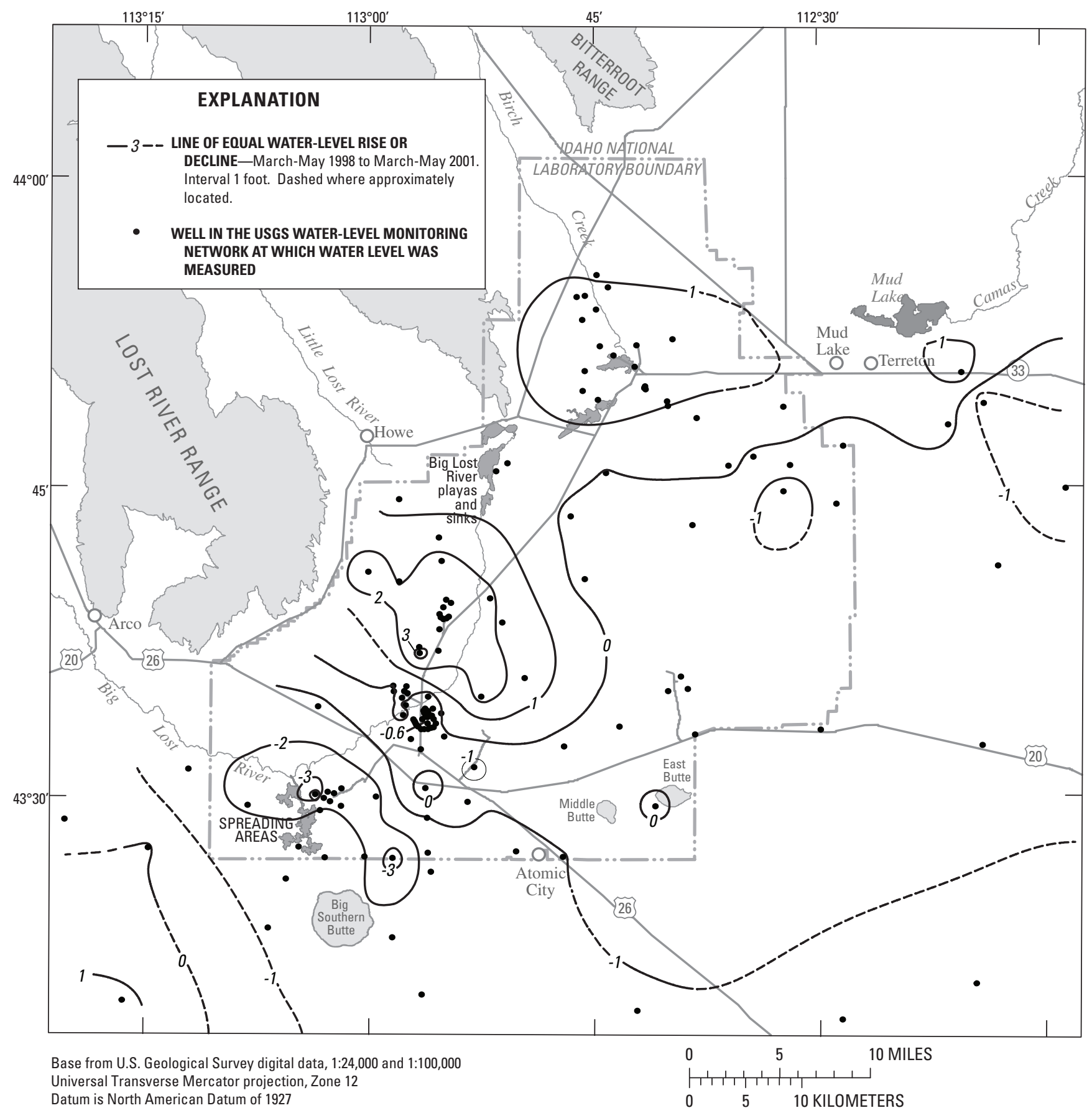

Figure 10. Generalized rise or decline in ground-water levels in the Snake River Plain aquifer in the vicinity of the Idaho National Laboratory (INL), Idaho, March-May 1998 to March-May 2001. 


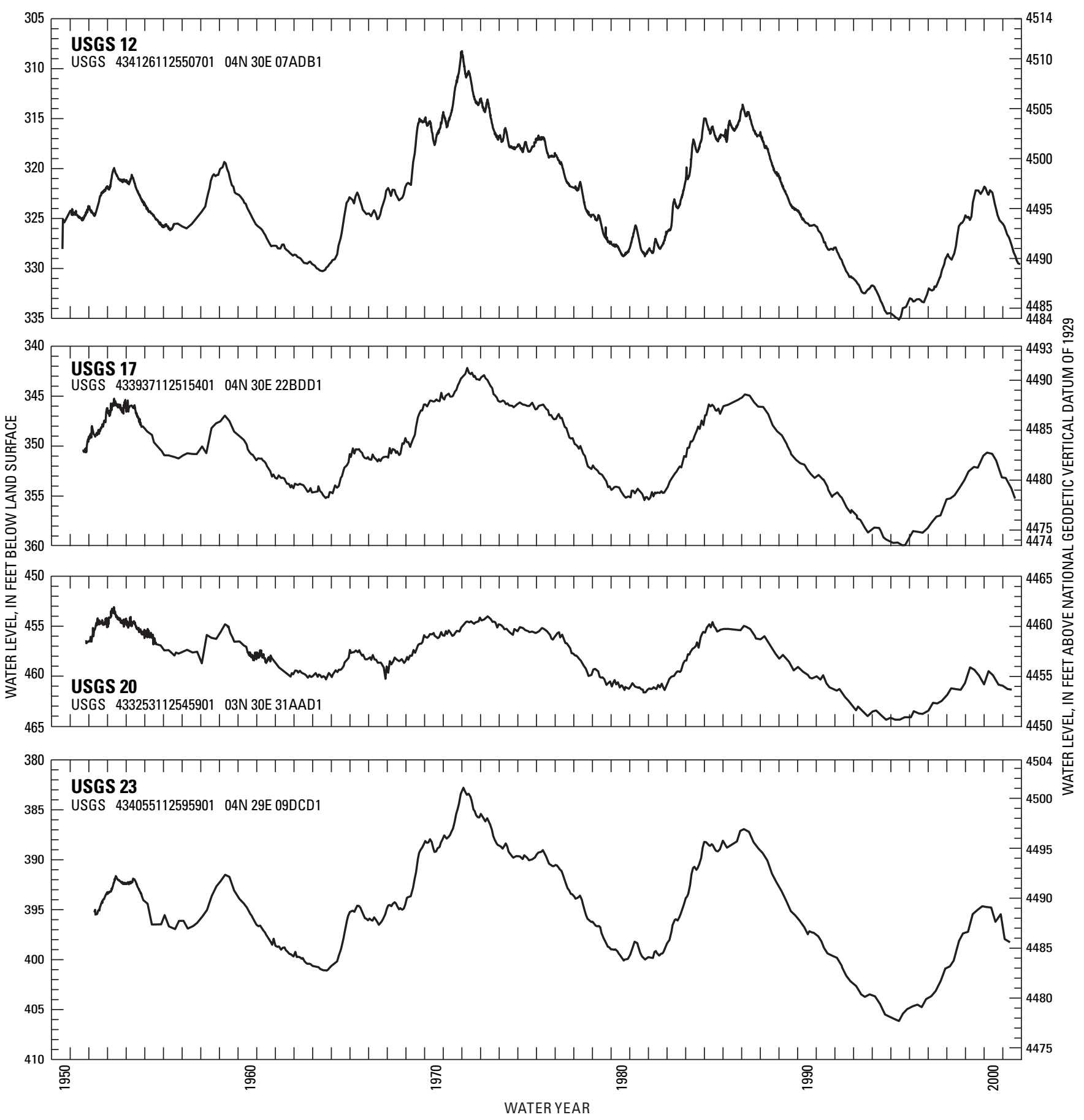

Figure 11. Water levels in four wells in the central part of the Idaho National Laboratory (INL), Idaho, 1950-2001. 


\section{Guidelines for Interpreting Results of Radiochemical Analyses}

Concentrations of radionuclides are reported with an estimated sample standard deviation, $s$, that is obtained by propagating sources of analytical uncertainty in measurements. The following guidelines for interpreting analytical results are based on an extension of a method proposed by Currie (1984).

In the analysis for a particular radionuclide, laboratory measurements are made on a target sample and a prepared blank. Instrument signals for the sample and the blank vary randomly. Therefore, it is essential to distinguish between two key aspects of the problem of detection: (1) the instrument signal for the sample must be larger than the signal observed for the blank before the decision can be made that the radionuclide was detected, and (2) an estimation must be made of the minimum radionuclide concentration that will yield a sufficiently large observed signal before the correct decision can be made for detection or nondetection of the radionuclide. The first aspect of the problem is a qualitative decision based on an observed signal and a definite criterion for detection. The second aspect of the problem is an estimation of the detection capabilities of a given measurement process.

In the laboratory, instrument signals must exceed a critical level of $1.6 s$, where $s$ is the sample standard deviation, before the qualitative decision can be made as to whether the radionuclide was detected. At $1.6 s$, there is about a 95-percent probability that the correct conclusion-not detected-will be made. Given a large number of samples, as many as 5 percent of the samples with measured concentrations greater than or equal to $1.6 \mathrm{~s}$, which were concluded as being detected, might not contain the radionuclide. These measurements are referred to as false positives and are errors of the first kind in hypothesis testing.

Once the critical level of $1.6 s$ has been defined, the minimum detectable concentration may be determined. Concentrations that equal $3 s$ represent a measurement at the minimum detectable concentration. For actual concentrations of $3 s$ or larger, there is a 95-percent or larger probability that the radionuclide was detected in a sample. In a large number of samples, the conclusion - not detected-will be made in 5 percent of the samples that contain actual concentrations at the minimum detectable concentration of $3 s$. These measurements are referred to as false negatives and are errors of the second kind in hypothesis testing.

Actual radionuclide concentrations between $1.6 s$ and $3 s$ have larger errors of the second kind. That is, there is a largerthan-5-percent probability of false negative results for samples with actual concentrations between $1.6 s$ and $3 s$. Although the radionuclide might have been detected, such detection may not be considered reliable; at $1.6 s$, the probability of a false negative is about 50 percent.
The critical level and minimum detectable concentration are based on counting statistics alone and do not include systematic or random errors inherent in laboratory procedures. The values $1.6 s$ and $3 s$ vary slightly with background or blank counts, with the number of gross counts for individual analyses, and for different radionuclides.

In this report, radionuclide concentrations less than $3 s$ are considered to be less than a "reporting level." The critical level, minimum detectable concentration, and reporting level aid the reader in the interpretation of analytical results and do not represent absolute concentrations of radioactivity, which may or may not have been detected. Analytical uncertainties are reported as $1 \mathrm{~s}$ in this report for consistency with conventions used in previous reports.

\section{Guidelines for Interpreting Results of Chemical Analyses}

Historically, the NWQL has used a minimum reporting level (MRL) to report nondetected concentrations or concentrations less than the MRL. The MRL for chemical constituents is the lowest measured concentration of a constituent that may be reliably reported using a given analytical method (Timme, 1995). This was the "less than" value reported by the NWQL. However, the NWQL found that establishment of MRLs was often inconsistent, undefined, undocumented, and subjective (Childress and others, 1999). In 1998, the NWQL began implementing new reporting procedures for some analytical methods based on long-term method detection levels. Childress and others (1999, p. 16) explained the new reporting procedures used by the NWQL as follows:
"The USGS National Water Quality Laboratory collects quality-control data on a continuing basis to evaluate selected analytical methods to determine long-term method detection levels (LT-MDLs) and laboratory reporting levels (LRLs). These values are re-evaluated each year on the basis of the most recent quality control data and, consequently, may change from year to year.

This reporting procedure limits the occurrence of false positive error. The chance of falsely reporting a concentration greater than the LT-MDL for a sample in which the analyte is not present is 1 percent or less. Application of the LRL limits the occurrence of false negative error. The chance of falsely reporting a non-detection for a sample in which the analyte is present at a concentration equal to or greater than the LRL is 1 percent or less. 
Accordingly, concentrations are reported as $<\mathrm{LRL}$ for samples in which the analyte was either not detected or did not pass identification. Analytes that are detected at concentrations between the LT-MDL and LRL and that pass identification criteria are estimated. Estimated concentrations will be noted with a remark code of "E." These data should be used with the understanding that their uncertainty is greater than that of data reported without the " $\mathrm{E}$ " remark code."

New LRLs were established for some analytical methods during 1999-2001. In this report, concentrations determined using these methods are reported as greater than the LRL; those determined using other methods are reported as greater than the MRL. Estimated concentrations less than the LRLs are treated as nondetected concentrations for consistency with treatment in previous publications, and because an estimated concentration is considered a "qualitatively detected analyte" (Childress and others, 1999, p. 7).

\section{Selected Radiochemical and Chemical Constituents and Physical Properties of Water in the Snake River Plain Aquifer, 1999-2001}

Contaminant plumes of radiochemical and chemical constituents in the Snake River Plain aquifer at the INL are attributed to waste-disposal practices. Areal distribution of the plumes were interpreted from analyses of samples collected from a 3-dimensional flow system. Concentrations of these constituents represent samples collected during October 2001 from various depths in the aquifer and with differing well completions; for example, single and multiple screened intervals, and open boreholes. No attempt was made to determine the vertical extent and distribution of these plumes. Radiochemical and chemical constituents analyzed for in ground-water samples collected at the INL during 1999-2001 include tritium, strontium-90, cesium-137, plutonium-238, plutonium-239, -240 (undivided), americium-241, gross alphaand beta-particle radioactivity, chromium and other trace elements, sodium, chloride, sulfate, nitrate, fluoride, purgeable organic compounds, and total organic carbon.

\section{Tritium}

A tritium plume has developed in the Snake River Plain aquifer from discharge of wastewater at the INL since the 1950s. Tritium has a half-life of 12.3 years (Walker and others, 1989, p. 20). The principal sources of tritium in the aquifer have been the injection of wastewater through the disposal well at INTEC and the discharge of wastewater to the infiltration ponds at the INTEC and RTC (fig. 5). Routine use of the disposal well at INTEC ended in February 1984; subsequently, radioactive wastewater has been discharged to the infiltration ponds. About 31,620 Ci of tritium in wastewater was discharged to the well and infiltration ponds from 1952 to 1998 (Bartholomay and others, 2000). Since 1993, tritium in wastewater at the RTC has been discharged to lined evaporation ponds, which should prevent migration to the aquifer. About $191 \mathrm{Ci}$ of tritium were released in wastewater to the RTC lined evaporation ponds during 1999-2000 (Stoller Corp., 2002a, 2002b). During 1996-99, no tritium was discharged to the ponds at the INTEC; during 2000, $0.03 \mathrm{Ci}$ of tritium was discharged (Stoller Corp., 2002a, 2002b) (fig. 7). Data for the total amount of tritium in wastewater discharged in 2001 are unavailable.

In October 2001, concentrations of tritium in water that exceeded the reporting level ranged from $0.43 \pm 0.14$ to $13.6 \pm 0.6 \mathrm{pCi} / \mathrm{mL}$ and the tritium plume extended southsouthwestward in the general direction of ground-water flow (fig. 12). The area of the plume in which concentrations exceeded the maximum contaminant level (MCL) of $20 \mathrm{pCi} / \mathrm{mL}$ (U.S. Environmental Protection Agency, 2001) was about $2.4 \mathrm{mi}^{2}$ in 1991 (Bartholomay and others, 1995). In 1995, five wells sampled by the USGS located in different areas of the INL had concentrations of tritium that exceeded the MCL, but no plume representing values equal to or greater than the MCL was discernible (Bartholomay and others, 1997). By October 1998, concentrations of tritium in all water samples were less than the MCL. This trend continued through October 2001, when concentrations of tritium in water samples generally decreased and were all less than the MCL.

Long-term radioactive-decay processes and an overall decrease in tritium disposal rates contributed to decreased concentrations of tritium in water from most of the wells at the INL during 1999-2001. Tritium concentrations in water from several wells south of the INTEC were smaller in 2001 than those measured in 1998. Concentrations decreased by as much as $8.3 \mathrm{pCi} / \mathrm{mL}$ during $1999-2001$. Concentrations in water from well USGS 123 (fig. 5), southwest of the INTEC, decreased from $16.6 \pm 0.7 \mathrm{pCi} / \mathrm{mL}$ in April 1998 to $8.3 \pm 0.4 \mathrm{pCi} / \mathrm{mL}$ in April 2001. Concentrations in water from well USGS 114 decreased from $19.7 \pm 0.8$ to $13.2 \pm 0.5 \mathrm{pCi} / \mathrm{mL}$ from July 1998 to July 2001. Concentrations in water from well USGS 77 decreased from $19.7 \pm 0.8$ to $14.1 \pm 035 \mathrm{pCi} / \mathrm{mL}$ from April 1998 to April 2001. Concentrations in well CFA LF 3-9 (fig. 5), north of the Central Facilities Area, decreased from $14.8 \pm 0.6$ to $9.3 \pm 0.5 \mathrm{pCi} / \mathrm{mL}$ from July 1998 to October 2001. The decrease in tritium concentrations in water from wells south of the INTEC could be the result of the decrease in discharge of tritium to the infiltration ponds since the early 1990s. 


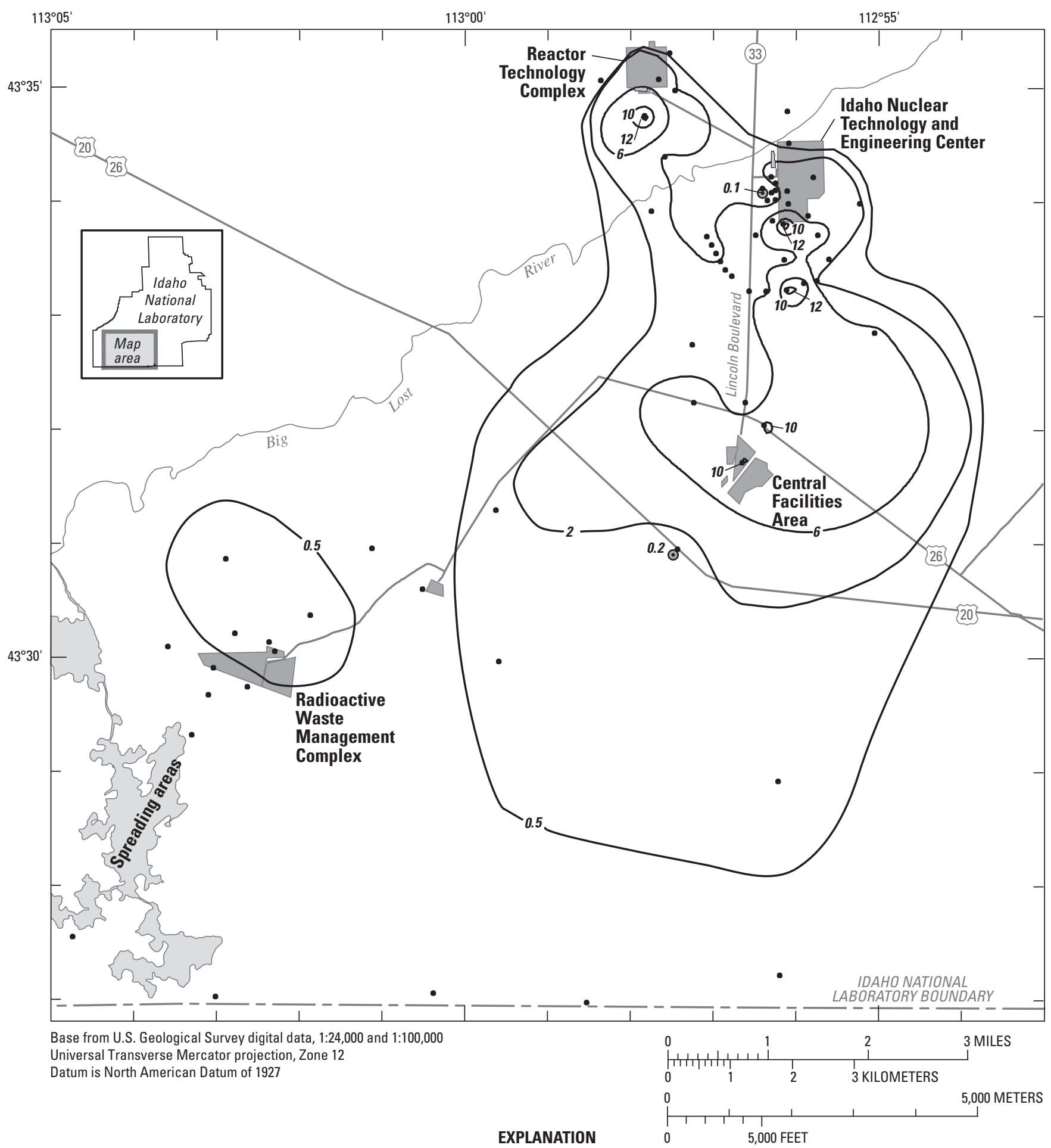

-10- LINE OF EQUAL TRITIUM CONCENTRATION-October 2001. Lines of equal concentration were interpreted from analyses of samples collected from a 3-dimensional flow system. Mapped concentrations represent samples collected from various depths in boreholes with differing well completions; for example, single- and multiplescreened intervals, and open boreholes. Location is approximate. Interval, in picocuries per milliliter, is variable

- WELL IN THE USGS WATER-QUALITY MONITORING NETWORK-Samples analyzed for tritium

0.2 Well value less than line of equal concentration

Figure 12. Distribution of tritium in water from wells at and near the Reactor Technology Complex (RTC), Idaho Nuclear Technology and Engineering Center (INTEC), Central Facilities Area (CFA), and Radioactive Waste Management Complex (RWMC) at the Idaho National Laboratory (INL), Idaho, October 2001. 
Near the southern boundary of the INL, tritium concentrations in water from wells USGS 103, 105, and 108 (fig. 4), exceeded the reporting level during 1983-85 (Pittman and others, 1988, p. 51; Mann and Cecil, 1990, p. 27). From 1985 to 1995 , tritium concentrations in water from these wells were less than the reporting level (Bartholomay and others, 1997, p. 27). In October 1998, concentrations in water from well USGS 105, at the boundary, and from well USGS 124 , south of the boundary, exceeded the reporting level and were $0.31 \pm 0.06$ and $0.3 \pm 0.06 \mathrm{pCi} / \mathrm{mL}$, respectively. These concentrations are similar to tritium concentrations reported by Busenberg and others (2000) from these two wells. Lower detection limits for tritium established by the RESL in the mid-1990s allowed for smaller concentrations of tritium to be identified during 1996-98. During 1999-2001, concentrations of tritium in water from wells near the southern boundary of the INL (USGS 1, 103, 105, 108, 109, 110A) (fig. 4) and all wells sampled south of the INL boundary were less than the reporting level.
Tritium concentrations in water from wells USGS 83 and EBR 1 (fig. 4) within and near the tritium plume (fig. 12) were less than the reporting level during 1999-2001. Well USGS 83 penetrates about $250 \mathrm{ft}$ of the Snake River Plain aquifer and well EBR 1 penetrates about $490 \mathrm{ft}$ of the aquifer. Most of the other wells in the tritium plume penetrate only the uppermost 50 to $200 \mathrm{ft}$ of the aquifer. Tritium concentrations in water from wells USGS 83 and EBR 1 were less than the reporting level possibly because of dilution by water from deeper zones, a phenomena described by Mann and Cecil (1990, p. 18) for these wells.

Tritium concentrations in water from wells south of the disposal well at INTEC (fig. 5) generally decreased during 1980-2001 (table 3) in response to a decreased rate of tritium disposal from the INTEC and radioactive decay. Tritium concentrations in water from well USGS 59, near the INTEC infiltration ponds (fig. 5), generally have decreased since 1980, but were unusually large in October 1983, 1985, 1991, and 1995 (table 3). The larger concentrations in 1983 and 1985

Table 3. Tritium concentrations in water from selected wells at and near the Central Facilities Area and the Idaho Nuclear Technology and Engineering Center, Idaho National Laboratory, Idaho, 1980-2001.

[Well No: Locations of wells are shown in figures 4 and $\underline{5}$. Concentrations and associated uncertainties in picocuries per milliliter. Analytical uncertainties are reported as 1 times the sample standard deviation. Concentrations equal to or greater than 3 times the sample standard deviation are considered to be greater than the reporting level. Abbreviations: USGS, U.S. Geological Survey; NS, not sampled. Symbols: \pm , plus or minus; -, no data, well drilled in 1984]

\begin{tabular}{|c|c|c|c|c|c|c|c|c|c|c|c|}
\hline \multicolumn{12}{|c|}{ Well No. } \\
\hline \multicolumn{2}{|c|}{ CFA 1} & \multicolumn{2}{|c|}{ USGS 38} & \multicolumn{2}{|c|}{ USGS 47} & \multicolumn{2}{|c|}{ USGS 59} & \multicolumn{2}{|c|}{ USGS 77} & \multicolumn{2}{|c|}{ USGS 111} \\
\hline Date & $\begin{array}{c}\text { Concen- } \\
\text { tration }\end{array}$ & Date & $\begin{array}{c}\text { Concen- } \\
\text { tration }\end{array}$ & Date & $\begin{array}{c}\text { Concen- } \\
\text { tration }\end{array}$ & Date & $\begin{array}{c}\text { Concen- } \\
\text { tration }\end{array}$ & Date & $\begin{array}{c}\text { Concen- } \\
\text { tration }\end{array}$ & Date & $\begin{array}{c}\text { Concen- } \\
\text { tration }\end{array}$ \\
\hline $10-21-80$ & $41.0 \pm 0.6$ & $10-17-80$ & $87.8 \pm 1.1$ & $10-13-80$ & $27.9 \pm 0.6$ & $10-24-80$ & $31.5 \pm 0.6$ & $10-13-80$ & $93.7 \pm 1.1$ & - & - \\
\hline $10-13-81$ & $35.6 \pm 0.6$ & $10-08-81$ & $77.5 \pm 0.8$ & $10-08-81$ & $27.9 \pm 0.6$ & $10-06-81$ & $29.7 \pm 0.6$ & $10-05-81$ & $79.9 \pm 0.8$ & - & - \\
\hline $10-11-82$ & $33.1 \pm 0.6$ & $10-07-82$ & $74.1 \pm 0.8$ & $10-07-82$ & $15.3 \pm 0.4$ & $10-06-82$ & $25.2 \pm 0.4$ & $09-30-82$ & $81.5 \pm 0.8$ & - & - \\
\hline $10-06-83$ & $31.5 \pm 0.6$ & $10-13-83$ & $70.9 \pm 0.9$ & $10-17-83$ & $73.0 \pm 0.9$ & $10-13-83$ & $59.7 \pm 0.9$ & $10-04-83$ & $63.5 \pm 0.9$ & - & - \\
\hline $10-12-84$ & $33.8 \pm 1.2$ & $10-09-84$ & $66.7 \pm 0.9$ & $10-23-84$ & $14.0 \pm 0.5$ & $10-10-84$ & $14.1 \pm 0.5$ & $10-09-84$ & $70.5 \pm 0.9$ & - & - \\
\hline $10-25-85$ & $32.4 \pm 0.8$ & $10-28-85$ & $55.8 \pm 1.7$ & $10-29-85$ & $12.0 \pm 0.6$ & $10-30-85$ & $42.0 \pm 1.3$ & $10-29-85$ & $46.3 \pm 1.4$ & $11-05-85$ & $29.5 \pm 1.0$ \\
\hline $10-31-86$ & $34.8 \pm 1.1$ & $11-18-86$ & $59.5 \pm 1.7$ & $10-29-86$ & $5.8 \pm 0.4$ & $11-14-86$ & $16.7 \pm 0.7$ & $11-13-86$ & $70.0 \pm 1.7$ & $10-27-86$ & $49.2 \pm 1.4$ \\
\hline $10-15-87$ & $32.1 \pm 1.0$ & $10-16-87$ & $65.9 \pm 1.9$ & $10-26-87$ & $3.5 \pm 0.4$ & $10-06-87$ & $3.6 \pm 0.4$ & $10-20-87$ & $60.2 \pm 1.7$ & $09-25-87$ & $57.5 \pm 1.7$ \\
\hline $10-28-88$ & $27.3 \pm 0.7$ & $11-07-88$ & $53.2 \pm 1.1$ & $09-30-88$ & $3.5 \pm 0.3$ & $10-21-88$ & $3.3 \pm 0.3$ & $11-06-88$ & $50.5 \pm 1.0$ & $10-04-88$ & $37.6 \pm 0.8$ \\
\hline $10-26-89$ & $22.0 \pm 0.6$ & $10-31-89$ & $40.2 \pm 0.9$ & $10-19-89$ & $5.0 \pm 0.3$ & $10-23-89$ & $2.4 \pm 0.2$ & $10-30-89$ & $41.2 \pm 0.9$ & $10-04-89$ & $29.4 \pm 0.7$ \\
\hline $10-15-90$ & $17.2 \pm 0.5$ & $10-05-90$ & $31.9 \pm 0.8$ & $10-31-90$ & $7.5 \pm 0.4$ & $10-12-90$ & $6.7 \pm 0.3$ & $10-25-90$ & $40.7 \pm 0.9$ & $09-24-90$ & $32.9 \pm 0.8$ \\
\hline $10-10-91$ & $21.1 \pm 0.6$ & $10-03-91$ & $26.3 \pm 0.7$ & $10-24-91$ & $6.2 \pm 0.3$ & $10-21-91$ & $19.3 \pm 0.6$ & $10-09-91$ & $41.7 \pm 1.0$ & $10-25-91$ & $18.3 \pm 0.6$ \\
\hline $10-08-92$ & $16.4 \pm 0.5$ & $10-14-92$ & $21.3 \pm 0.6$ & $10-21-92$ & $10.8 \pm 0.4$ & $10-23-92$ & $5.6 \pm 0.6$ & $10-09-92$ & $36.8 \pm 0.9$ & $10-09-92$ & $16.0 \pm 0.5$ \\
\hline $10-93$ & NS & $10-23-93$ & $16.2 \pm 0.7$ & $10-26-93$ & $6.0 \pm 0.4$ & $10-25-93$ & $3.4 \pm 0.3$ & $10-23-93$ & $31.5 \pm 1.2$ & $10-21-93$ & $13.0 \pm 0.6$ \\
\hline $10-94$ & NS & $10-14-94$ & $15.1 \pm 0.7$ & $10-19-94$ & $9.9 \pm 0.5$ & $11-01-94$ & $3.5 \pm 0.3$ & $10-07-94$ & $28.7 \pm 1.1$ & $10-13-94$ & $10.5 \pm 0.5$ \\
\hline $10-11-95$ & $13.4 \pm 0.6$ & $10-12-95$ & $13.0 \pm 0.6$ & $10-16-95$ & $7.6 \pm 0.4$ & $10-23-95$ & $13.0 \pm 0.6$ & $10-24-95$ & $25.1 \pm 1.0$ & $10-26-95$ & $7.0 \pm 0.4$ \\
\hline $10-16-96$ & $17.8 \pm 0.8$ & $10-25-96$ & $11.8 \pm 0.6$ & $10-21-96$ & $13.6 \pm 0.7$ & $10-29-96$ & $3.1 \pm 0.3$ & $10-17-96$ & $24.0 \pm 1.0$ & $10-17-96$ & $8.2 \pm 0.5$ \\
\hline $10-21-97$ & $14.2 \pm 0.6$ & $10-09-97$ & $8.2 \pm 0.4$ & $10-14-97$ & $9.7 \pm 0.5$ & $10-22-97$ & $2.5 \pm 0.2$ & $10-16-97$ & $18.2 \pm 0.7$ & $10-28-97$ & $7.8 \pm \mathrm{v} 0.4$ \\
\hline $10-19-98$ & $12.6 \pm 0.6$ & $10-19-98$ & $7.9 \pm 0.4$ & $10-28-98$ & $4.6 \pm 0.3$ & $10-27-98$ & $1.9 \pm 0.2$ & $10-13-98$ & $18.2 \pm 0.7$ & $10-26-98$ & $6.4 \pm \mathrm{v} 0.3$ \\
\hline $10-20-99$ & $13.9 \pm 0.6$ & $10-19-99$ & $6.6 \pm 0.4$ & $10-20-99$ & $1.9 \pm 0.2$ & $10-06-99$ & $1.6 \pm 0.2$ & $10-05-99$ & $15.0 \pm 0.6$ & $10-06-99$ & $5.8 \pm 0.3$ \\
\hline $10-11-00$ & $11.0 \pm 0.5$ & $10-11-00$ & $5.0 \pm 0.3$ & $10-18-00$ & $1.1 \pm 0.2$ & $10-02-00$ & $0.9 \pm 0.2$ & $10-06-00$ & $11.8 \pm 0.5$ & $10-03-00$ & $3.6 \pm 0.3$ \\
\hline $10-09-01$ & $10.4 \pm 0.5$ & $10-11-01$ & $6.0 \pm 0.4$ & $10-15-01$ & $4.0 \pm 0.3$ & $10-18-01$ & $3.4 \pm 0.3$ & $10-24-01$ & $13.4 \pm 0.6$ & $10-18-01$ & $4.7 \pm 0.3$ \\
\hline
\end{tabular}


correlate with higher annual tritium discharge rates, however, annual tritium discharge was low in 1991 and 1995 (fig. 7). In 1986, perched water was detected outside the casing in well USGS 59. Following modifications to the well to prevent seepage of water into the well, a video log showed that some water from the perched zone was still seeping into the well. The larger concentrations in 1991 and 1995 could be the result of seepage from a perched zone. The larger concentrations also correlate with the use of the east infiltration pond and with disposal of tritium to the ponds. The smaller concentrations in water from well USGS 59 in 1989, 1993, 1994, and from 1996 to 2000 correlate with years in which little or no tritium was discharged to the infiltration ponds (fig. 7). The slight increase in tritium concentrations in wells USGS 38, 47, 59, 77, and 111 between 2000 and 2001 (table 3), could be a result of the disposal of $0.03 \mathrm{Ci}$ of tritium (Stoller Corp., 2002b) to the INTEC infiltration ponds during 2000 and the lack of dilution by ground-water recharge because of low streamflows in the Big Lost River during that year.

\section{Strontium-90}

A strontium-90 plume has developed in the Snake River Plain aquifer from the disposal of wastewater at the INL. Strontium-90 has a half-life of 29.1 years (Walker and others, 1989, p. 29). During 1952-98, about 24 Ci of strontium-90 was in wastewater injected directly into the aquifer through the disposal well and discharged to infiltration ponds at the INTEC (Bartholomay and others, 2000). During this time period, about $93 \mathrm{Ci}$ of strontium-90 also was discharged to radioactive-waste infiltration and evaporation ponds at the RTC. During 1962-63, more than $33 \mathrm{Ci}$ of strontium-90 in wastewater was discharged into a pit at the INTEC (Robertson and others, 1974, p. 117). During 1996-98, about $0.03 \mathrm{Ci}$ of strontium-90 was discharged to infiltration ponds at the INTEC (Bartholomay and others, 2000). During 1999, less than $0.001 \mathrm{Ci}$ of strontium-90 was discharged at the INTEC or RTC (Stoller Corp., 2002a, table 7-2); during 2000, 0.21 Ci of strontium-90/yttrium-90 was discharged at the RTC (Stoller Corp., 2002b, table 6-2). Data are unavailable for the amount of strontium-90 discharged in 2001.

In October 2001, concentrations of strontium-90 in water from 19 wells exceeded the reporting level. However, concentrations from most wells have remained relatively constant or decreased since 1989 (table 4). Concentrations ranged from $2.1 \pm 0.7$ to $42.4 \pm 1.4 \mathrm{pCi} / \mathrm{L}$ and the area where strontium-90 was detected extended south-southwestward in the general direction of ground-water flow (fig. 13). The concentrations in water from wells USGS 37 and 45 have varied since 1980, but decreased between 1999-2001 (table 4). Concentrations in water from well USGS 37 exceeded the reporting level during 1980-2001, but were less than the reporting level in 1991 and 1995 (table 4). Concentrations in water from well USGS 45 were equal to or less than the reporting level for most years from 1984 to 2001, but exceeded the reporting level in 1990, 1991, 1993, 1998, and in a replicate sample collected in 1995 (table 4). The October 1995 concentration of $76 \pm 3 \mathrm{pCi} / \mathrm{L}$ in water from well USGS 47 was larger than concentrations in most previous samples, but the quality-assurance replicate concentration of $47 \pm 2 \mathrm{pCi} / \mathrm{L}$ was similar to concentrations in most previous samples. The concentrations of strontium-90 in this well show an overall decrease since 1996. The concentrations in wells USGS 57 and 113 generally decreased from the 1980s to 2001, although the concentration in well USGS 57 increased between 2000-2001 (table 4). The MCL for strontium-90 in drinking water is $8 \mathrm{pCi} / \mathrm{L}$ (U.S. Environmental Protection Agency, 2001).

Before 1989, strontium-90 concentrations in most wells had been decreasing likely because of a combination of factors including changes in disposal methods, radioactive decay, diffusion, dispersion, and dilution from natural recharge (Orr and Cecil, 1991, p. 35). The relatively constant concentrations in water from most of the wells sampled during 1992-95 could have been partly a result of a lack of recharge from the Big Lost River. An increase in disposal of other chemical constituents into the infiltration ponds also could have affected the exchange capacity of strontium-90 in the unsaturated zone (Bartholomay and others, 1997). The decrease of strontium-90 concentrations in water from some wells during 1999-2001 could be the result of the factors previously mentioned.

Strontium-90 has not been detected in the eastern Snake River Plain aquifer beneath the RTC. This can be explained partly by the exclusive use of waste-disposal ponds and lined evaporation ponds rather than the disposal well for radioactive-wastewater disposal at the RTC. Sorption processes in sediments in the unsaturated zone beneath the radioactive waste-disposal pond could have minimized or prevented strontium-90 migration to the aquifer at the RTC. In addition, the stratigraphy beneath the RTC is different from that beneath the INTEC in that more sediment is present below the RTC (Anderson, 1991, p. 22-28).

\section{Cobalt-60}

During 1952-93, about $438 \mathrm{Ci}$ of cobalt-60 in wastewater was discharged to the RTC radioactive-waste infiltration ponds. Before 1974, the average disposal rate was about $18 \mathrm{Ci} / \mathrm{yr}$; during 1974-88, the average disposal rate was 2.3 Ci/yr (Orr and Cecil, 1991, p. 35). During 1989-91, about 0.5 $\mathrm{Ci}$ of cobalt-60 was discharged to the ponds; during 1992-93, about $3.1 \mathrm{Ci}$ of cobalt was discharged to the ponds. The halflife of cobalt-60 is 5.27 years (Walker and others, 1989, p. 25). 
Table 4. Strontium-90 concentrations in water from selected wells at and near the Idaho Nuclear Technology and Engineering Center, Idaho National Laboratory, Idaho, 1980-2001.

[Well No: Location of wells are shown in figure 5. Concentrations and associated uncertainties in picocuries per liter. Analytical uncertainties are reported as 1 times the sample standard deviation. Concentrations equal to or greater than 3 times the sample standard deviation are considered to be greater than the reporting level. Abbreviations: USGS,

U.S. Geological Survey; QA, quality-assurance replicate. Symbols: \pm , plus or minus; -, no data, well drilled in 1984]

\begin{tabular}{|c|c|c|c|c|c|c|c|}
\hline \multicolumn{8}{|c|}{ Well No. } \\
\hline \multicolumn{2}{|c|}{ USGS 36} & \multicolumn{2}{|c|}{ USGS 37} & \multicolumn{2}{|c|}{ USGS 38} & \multicolumn{2}{|c|}{ USGS 45} \\
\hline Date & $\begin{array}{l}\text { Concen- } \\
\text { tration }\end{array}$ & Date & $\begin{array}{l}\text { Concen- } \\
\text { tration }\end{array}$ & Date & $\begin{array}{l}\text { Concen- } \\
\text { tration }\end{array}$ & Date & $\begin{array}{c}\text { Concen- } \\
\text { tration }\end{array}$ \\
\hline $10-17-80$ & $17 \pm 2$ & $10-13-80$ & $22 \pm 3$ & $10-17-80$ & $22 \pm 3$ & $10-24-80$ & $23 \pm 3$ \\
\hline $10-08-81$ & $24 \pm 2$ & $10-07-81$ & $25 \pm 3$ & $10-08-81$ & $28 \pm 3$ & $10-06-81$ & $71 \pm 5$ \\
\hline $10-07-82$ & $10 \pm 2$ & $10-07-82$ & $30 \pm 3$ & $10-07-82$ & $27 \pm 3$ & $10-06-82$ & $79 \pm 5$ \\
\hline $10-13-83$ & $15 \pm 2$ & $10-10-83$ & $26 \pm 3$ & $10-13-83$ & $12 \pm 2$ & $10-12-83$ & $37 \pm 3$ \\
\hline $10-09-84$ & $32 \pm 4$ & $10-10-84$ & $17 \pm 2$ & $10-09-84$ & $26 \pm 4$ & $10-09-84$ & $2 \pm 2$ \\
\hline $10-28-85$ & $40 \pm 4$ & $10-28-85$ & $18 \pm 3$ & $10-28-85$ & $14 \pm 2$ & $10-29-85$ & $6 \pm 2$ \\
\hline $11-18-86$ & $10 \pm 2$ & $10-27-86$ & $21 \pm 2$ & $11-18-86$ & $13 \pm 2$ & $11-14-86$ & $5 \pm 2$ \\
\hline $10-16-87$ & $33 \pm 3$ & $10-05-87$ & $17 \pm 2$ & $10-16-87$ & $13 \pm 2$ & $10-20-87$ & $2.8 \pm 1.4$ \\
\hline $11-07-88$ & $16 \pm 2$ & $10-07-88$ & $14 \pm 2$ & $11-07-88$ & $32 \pm 3$ & $11-06-88$ & $0 \pm 2$ \\
\hline $10-31-89$ & $25 \pm 3$ & $09-29-89$ & $16 \pm 2$ & $10-31-89$ & $9 \pm 2$ & $11-02-89$ & $0.4 \pm 1.6$ \\
\hline $10-25-90$ & $17 \pm 2$ & $10-17-90$ & $14 \pm 2$ & $10-05-90$ & $22 \pm 3$ & $10-26-90$ & $14 \pm 2$ \\
\hline 10-08-91 & $14 \pm 3$ & $10-07-91$ & $-3 \pm 2$ & $10-03-91$ & $9 \pm 3$ & 10-09-91 & $16 \pm 2$ \\
\hline $10-28-92$ & $16 \pm 2$ & $10-02-92$ & $11 \pm 2$ & $10-14-92$ & $27 \pm 3$ & $11-13-92$ & $1.1 \pm 2.0$ \\
\hline $10-20-93$ & $14 \pm 3$ & $10-21-93$ & $20 \pm 3$ & $10-23-93$ & $25 \pm 3$ & $11-01-93$ & $8 \pm 2$ \\
\hline $10-13-94$ & $14 \pm 2$ & $10-07-94$ & $13 \pm 2$ & $10-14-94$ & $27 \pm 3$ & $10-17-94$ & $2.2 \pm 1.6$ \\
\hline $10-11-95$ & $8.7 \pm 1.0$ & $10-11-95$ & $0.3 \pm 1.1$ & $10-12-95$ & $23.5 \pm 1.4$ & $10-11-95$ & $1.6 \pm 0.9$ \\
\hline $10-23-96$ & $11.8 \pm 1.0$ & $10-24-96$ & $9.1 \pm 1$ & $10-25-96$ & $26 \pm 1.4$ & $10-11-95$ & $12 \pm 2 \mathrm{QA}$ \\
\hline $10-07-97$ & $13.4 \pm 1.1$ & $10-08-97$ & $9.9 \pm 1.2$ & $10-09-97$ & $22 \pm 2$ & $10-29-96$ & $1.9 \pm 1$ \\
\hline $10-15-98$ & $12.9 \pm 0.8$ & $10-15-98$ & $13.4 \pm 1$ & $10-19-98$ & $20.7 \pm 1.1$ & $10-16-97$ & $1.1 \pm 0.8$ \\
\hline $10-05-99$ & $13.0 \pm 0.9$ & $10-14-99$ & $11.0 \pm 0.9$ & $10-19-99$ & $20.0 \pm 1.1$ & $10-14-98$ & $2.1 \pm 0.6$ \\
\hline $10-17-00$ & $9.8 \pm 0.9$ & $10-11-00$ & $11.6 \pm 0.8$ & $10-11-00$ & $16.5 \pm 0.9$ & $10-20-99$ & $2.3 \pm 0.8$ \\
\hline $10-25-01$ & $8.9 \pm 0.8$ & $10-24-01$ & $9.3 \pm 0.8$ & 10-11-01 & $16.8 \pm 1.0$ & $10-18-00$ & $1.9 \pm 0.8$ \\
\hline & & & & & & $10-15-01$ & $0.4 \pm 0.6$ \\
\hline
\end{tabular}

\begin{tabular}{|c|c|c|c|c|c|}
\hline \multicolumn{2}{|c|}{ USGS 47} & \multicolumn{2}{|c|}{ USGS 57} & \multicolumn{2}{|c|}{ USGS 113} \\
\hline Date & $\begin{array}{l}\text { Concen- } \\
\text { tration }\end{array}$ & Date & $\begin{array}{c}\text { Concen- } \\
\text { tration }\end{array}$ & Date & $\begin{array}{c}\text { Concen- } \\
\text { tration }\end{array}$ \\
\hline $10-13-80$ & $107 \pm 6$ & $10-24-80$ & $88 \pm 5$ & - & - \\
\hline $10-08-81$ & $79 \pm 5$ & $10-05-81$ & $93 \pm 6$ & - & - \\
\hline $10-07-82$ & $60 \pm 4$ & $10-06-82$ & $90 \pm 5$ & - & - \\
\hline $10-17-83$ & $130 \pm 7$ & $10-13-83$ & $83 \pm 5$ & - & - \\
\hline $10-23-84$ & $61 \pm 4$ & $10-10-84$ & $66 \pm 5$ & - & - \\
\hline $10-29-85$ & $63 \pm 5$ & $10-29-85$ & $74 \pm 5$ & $11-01-85$ & $30 \pm 3$ \\
\hline $10-29-86$ & $56 \pm 4$ & $11-14-86$ & $42 \pm 3$ & $10-27-86$ & $27 \pm 3$ \\
\hline $10-26-87$ & $54 \pm 3$ & $10-09-87$ & $49 \pm 3$ & $10-02-87$ & $28 \pm 3$ \\
\hline $09-30-88$ & $48 \pm 3$ & $10-05-88$ & $41 \pm 3$ & $9-27-88$ & $27 \pm 3$ \\
\hline $10-19-89$ & $59 \pm 4$ & $12-22-89$ & $45 \pm 4$ & $10-06-89$ & $20 \pm 2$ \\
\hline $10-31-90$ & $51 \pm 4$ & $10-29-90$ & $41 \pm 4$ & $10-03-90$ & $16 \pm 3$ \\
\hline $10-24-91$ & $55 \pm 4$ & $10-24-91$ & $40 \pm 4$ & $10-08-91$ & $23 \pm 2$ \\
\hline $10-21-92$ & $56 \pm 4$ & $10-06-92$ & $41 \pm 4$ & $10-22-92$ & $16 \pm 2$ \\
\hline $10-26-93$ & $54 \pm 4$ & $10-12-93$ & $36 \pm 3$ & $10-23-93$ & $13 \pm 3$ \\
\hline $10-19-94$ & $55 \pm 4$ & $10-03-94$ & $27 \pm 3$ & $10-17-94$ & $14 \pm 2$ \\
\hline $10-16-95$ & $76 \pm 3$ & $10-11-95$ & $29.2 \pm 1.5$ & $10-17-95$ & $14.1 \pm 1.0$ \\
\hline $10-16-95$ & $47 \pm 2 \mathrm{QA}$ & $10-18-96$ & $30.5 \pm 1.5$ & $10-18-96$ & $14.8 \pm 1.1$ \\
\hline $10-21-96$ & $58 \pm 2$ & $10-14-97$ & $18.5 \pm 1.6$ & $10-16-97$ & $13 \pm 1.5$ \\
\hline $10-14-97$ & $41.8 \pm 1.6$ & $10-06-98$ & $20.8 \pm 1.1$ & $10-15-98$ & $12.2 \pm 0.9$ \\
\hline $10-28-98$ & $41.1 \pm 1.5$ & $10-05-99$ & $17.0 \pm 1.0$ & $10-19-99$ & $12.0 \pm 0.9$ \\
\hline $10-28-98$ & $43.9 \pm 1.6 \mathrm{QA}$ & $10-05-00$ & $15.7 \pm 0.9$ & $10-18-00$ & $11.5 \pm 1.0$ \\
\hline $10-20-99$ & $40.5 \pm 1.5$ & $10-25-01$ & $20.9 \pm 1.0$ & $10-10-01$ & $10.4 \pm 0.8$ \\
\hline $10-18-00$ & $35.8 \pm 1.3$ & & & & \\
\hline $10-15-01$ & $42.4 \pm 1.4$ & & & & \\
\hline
\end{tabular}




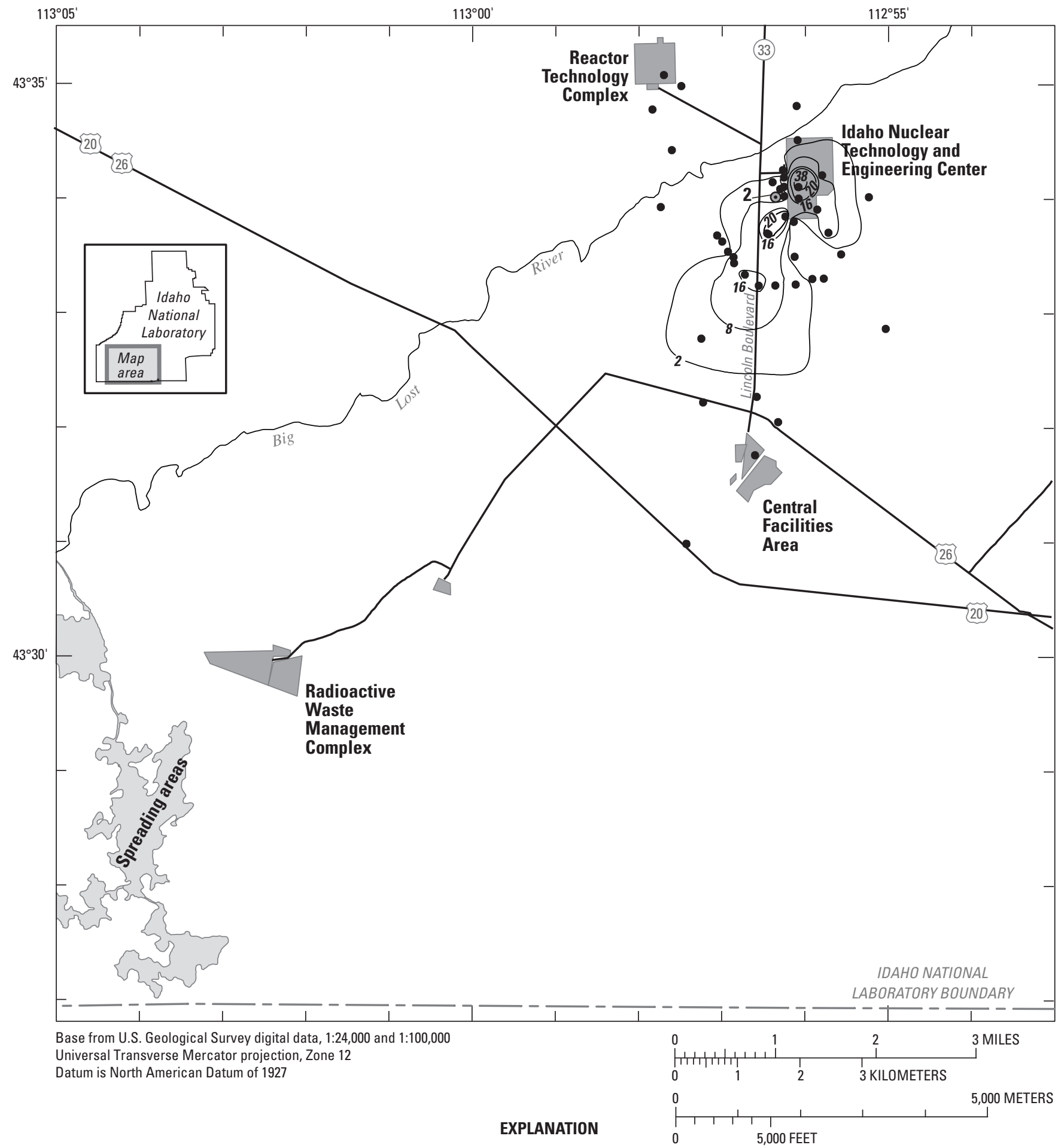

- 2 - LINE OF EQUAL STRONTIUM-90 CONCENTRATION-October 2001. Lines of equal concentrations were interpreted from analyses of samples collected from a 3-dimensional flow system. Mapped concentrations represent samples collected from various depths in boreholes with differing well completions; for example, single and multiple screened intervals, and open boreholes. Location is approximate. Interval, in picocuries per liter, is variable
- WELL IN THE USGS WATER-QUALITY MONITORING NETWORK—Samples analyzed for strontium-90

2 concentration

Figure 13. Distribution of strontium-90 in water from wells at and near the Reactor Technology Complex (RTC), Idaho Nuclear Technology and Engineering Center (INTEC), Central Facilities Area (CFA), and Radioactive Waste Management Complex (RWMC) at the Idaho National Laboratory (INL), Idaho, October 2001. 
Cobalt- 60 concentrations in water from well USGS 65 (fig. 5), south of the RTC, exceeded the reporting level through 1985 (Orr and Cecil, 1991, p. 35) but have not been detected since 1985. The decrease in discharge of cobalt-60 to the RTC radioactive-waste infiltration ponds, the change to use of lined evaporation ponds, and processes of radioactive decay and sorption in the unsaturated and perched ground-water zones could have contributed to the absence of detectable concentrations of cobalt-60 in ground water near the RTC since 1985.

Cobalt-60 concentrations in water from the TAN disposal well (fig. 4) exceeded the reporting level because of the discharge of radioactive wastewater to the well before 1972 . The responsibility for monitoring the TAN disposal well was turned over to a DOE contractor in 1988 as part of the Environmental Restoration Program. Samples were collected by the USGS in 1989 for special studies but no samples have been collected since December 1989. Water from the TAN disposal well contained $170 \pm 40 \mathrm{pCi} / \mathrm{L}$ of cobalt -60 in December 1989.

During 1996-98, cobalt-60 concentrations in water from all wells sampled by the USGS at the INL were less than the reporting level. Cobalt-60 was not detected in any samples collected during 1999-2001.

\section{Cesium-137}

From 1952 to 2000, about $138 \mathrm{Ci}$ of cesium-137 in wastewater was discharged to the RTC radioactive-waste infiltration and lined evaporation ponds and about $23 \mathrm{Ci}$ was discharged to the INTEC disposal well and infiltration ponds. During 1999-2000, about $0.009 \mathrm{Ci}$ was discharged to the RTC lined evaporation ponds, and less than $0.001 \mathrm{Ci} / \mathrm{yr}$ was discharged to the INTEC infiltration ponds (Stoller Corp., 2002a, table 7-2, footnote b; 2002b, table 6-2, footnote b). The half-life of cesium-137 is 30.17 years (Walker and others, 1989, p. 34).

Concentrations of cesium-137 in water from wells USGS 40 and 47 (fig. 5) exceeded the reporting levels through 1985 (Orr and Cecil, 1991, p. 35) but have been less than the reporting level since 1985 . The absence of detectable concentrations of cesium-137 probably is the result of the discontinuation of wastewater discharge to the INTEC disposal well and to sorption processes in the unsaturated and perched ground-water zones.

Cesium-137 concentrations in water from the TAN disposal well (fig. 4) exceeded the reporting level because of wastewater discharge to the well before 1972. Because the responsibility for monitoring the TAN disposal well was turned over to a DOE contractor in 1988, the only samples collected by the USGS were in December 1989 for special studies. The cesium-137 concentration at that time was 4,400 \pm 200 pCi/L (http://waterdata.usgs.gov/id/nwis/qw, accessed June 29, 2006).
During 1999-2001, concentrations of cesium-137 in water from all wells sampled by the USGS at the INL were less than the reporting level.

\section{Plutonium}

Monitoring of plutonium-238 and plutonium-239, -240 (undivided) in wastewater discharged to the Snake River Plain aquifer through the disposal well (fig. 5) at INTEC began in 1974. Before that time, alpha radioactivity from disintegration of plutonium was not separable from the monitored, undifferentiated alpha radioactivity. The half-lives of plutonium-238, plutonium-239, and plutonium-240 are 87.7; 24,100; and 6,560 years, respectively (Walker and others, 1989 , p. 46). During 1974-95, about $0.26 \mathrm{Ci}$ of plutonium in wastewater was discharged to the disposal well and infiltration ponds at the INTEC (Bartholomay and others, 1997). During 1996-98, about $0.004 \mathrm{Ci}$ of plutonium in wastewater was discharged to infiltration ponds at the INTEC. During 1999-2000, less than 0.001 Ci of plutonium was discharged (Stoller Corp., 2002a, table 7-2, footnote b; 2002b, table 6-2, footnote b). Discharge data for 2001 are unavailable.

Because of the radioactive wastewater discharged to the disposal well at INTEC, concentrations of plutonium isotopes in some samples from wells USGS 40 and 47 (fig. 5) through January 1987 exceeded the reporting level (Orr and Cecil, 1991, p. 37). Concentrations in samples collected from these wells since 1987 have been less than the reporting level.

Plutonium isotopes in water from the TAN disposal well (fig. 4) exceeded the reporting level because of radioactive-wastewater discharges before 1972. Because the responsibility for monitoring TAN disposal well was turned over to a DOE contractor in 1988, the only samples collected by the USGS since that time were collected in December 1989. The concentration of plutonium-238 in water from the TAN disposal well at that time was $0.26 \pm 0.04 \mathrm{pCi} / \mathrm{L}$ and the concentration of plutonium-239, -240 (undivided) was $0.71 \pm 0.06 \mathrm{pCi} / \mathrm{L}$ (Bartholomay and others, 1995).

During 1999-2001, concentrations in water from all wells sampled by the USGS at the INL were less than the reporting level.

\section{Americium-241}

Americium-241 is a decay product of plutonium-241 and plutonium isotopes have been detected in wastewater discharged to the Snake River Plain aquifer at the INL and are in wastes buried at the RWMC. The half-life of americium241 is 432.7 years (Walker and others, 1989, p. 46). Concentrations of americium-241 in water samples collected between September 1972 and July 1982 from wells USGS 87, 88, 89, and 90 at the RWMC (fig. 5) and in water samples collected through 1988 from the TAN disposal well (fig. 4) exceeded the reporting level (Orr and Cecil, 1991, p. 38-39). During 1992-95, the concentrations of americium241 in samples from each of two wells were equal to the 
reporting level. On October 2, 1992, the concentration in water from well USGS 37 was 0.09 \pm 0.03 pCi/L; on April 20, 1993, the concentration in water from well USGS 120 was $0.06 \pm 0.02 \mathrm{pCi} / \mathrm{L}$ (Bartholomay and others, 1997). During 1996-2001, concentrations in all samples were less than the reporting level with the exception of one sample from the RWMC Production Well, which had a concentration of $0.003 \pm 0.001 \mathrm{pCi} / \mathrm{L}$ on April 12, 2001, equal to the reporting level.

\section{Gross Alpha- and Beta-Particle Radioactivity}

Gross alpha- and beta-particle radioactivity is a measure of the total radioactivity given off as alpha and beta particles during the radioactive decay process. Gross alpha and beta measurements are used to screen for radioactivity in the aquifer as a possible indicator of ground-water contamination. Background concentrations of gross beta-particle radioactivity in the Snake River Plain aquifer in Idaho generally range from 0 to $7 \mathrm{pCi} / \mathrm{L}$ as cesium-137 (Knobel and others, 1992). Background concentrations of gross alpha particle radioactivity range from 0 to $3 \mu \mathrm{g} / \mathrm{L}$ as natural uranium (Knobel and others, 1992).

Before 1994, gross alpha- and beta-particle radioactivity in water from three wells west and south of the INL (wells USGS 8, 11, and 14, fig. 4) and four surface-water sites along the Big Lost River (fig. 1) were sampled. As part of the INL ground-water monitoring program adopted in 1994 (Sehlke and Bickford, 1993), the USGS expanded the number of wells at the INL used for sampling gross alpha- and gross betaparticle radioactivity.

During 1999-2001, water from 56 wells was sampled for gross alpha- and gross-beta particle radioactivity. Concentrations of gross alpha-particle radioactivity were less than the reporting level in all samples as they were in October 1998. Thirty-one of the 56 wells sampled had concentrations of gross-beta particle radioactivity greater than the reporting level in at least one sample collected during 1999-2001, and ranged from $6 \pm 2$ to $60 \pm 5 \mathrm{pCi} / \mathrm{L}$. Well USGS 57 had a concentration of $60 \pm 5$ pCi/L on July 6, 1999; however, this well had not previously been sampled for gross-beta particle activity. Gross-beta particle activity in most of the 31 wells showed steady or decreasing concentration trends during 1999-2001.

During September-October 2001, water in 23 wells was sampled for gross alpha- and gross-beta particle radioactivity. Concentrations of gross alpha-particle radioactivity were less than the reporting level in all samples. Concentrations of gross beta-particle radioactivity in water from 5 of the 23 wells sampled in October 2001 were greater than the reporting level and ranged from $6 \pm 2$ to $57 \pm 5 \mathrm{pCi} / \mathrm{L}$. Of the 23 wells sampled in October 2001, well USGS 38 had the largest concentration, and was the only well showing a generally increasing trend in gross-beta particle activity during 1999-2001. Well USGS 38 also is downgradient from well USGS 57 (fig. 3), which had the highest concentration of gross-beta particle activity for the 1999-2001 reporting period.

\section{Chromium}

Wastewater from RTC cooling-tower operations contained an estimated 24,000 $\mathrm{lb}$ of chromium that was discharged to an infiltration pond during 1952-64 and an estimated 31,000 $\mathrm{lb}$ that was discharged to an injection well during 1965-72 (Mann and Knobel, 1988, p. 7). In October 1972, chromium that was used as a corrosion inhibitor in cooling-tower operations was replaced by a polyphosphate. During 1971-83, about $265 \mathrm{lb}$ of chromium in wastewater was discharged to the disposal well at INTEC and $720 \mathrm{lb}$ of chromate was discharged at the Power Burst Facility (fig. 1) (Cassidy, 1984, p. 3). About 86 lbs of chromium was discharged to the INTEC infiltration ponds during 1992-95 (Bartholomay and others, 1997) and 44 lbs during 1996-98 (Bartholomay and others, 2000). No information has been compiled on the total amount of chromium discharged during 1999-2001.

Background concentrations of chromium in the Snake River Plain aquifer range from 2 to $3 \mu \mathrm{g} / \mathrm{L}$ (Orr and others, 1991, p. 41). In October 2001, the MCL of $100 \mu \mathrm{g} / \mathrm{L}$ (U.S. Environmental Protection Agency, 2001) for total chromium in drinking water was exceeded in water from one well, USGS 65, south of RTC (fig. 5). The concentration of chromium in water from that well was $139 \mu \mathrm{g} / \mathrm{L}$, a decrease from $168 \mu \mathrm{g} / \mathrm{L}$ in October 1998 (Bartholomay and others, 2000). Concentrations in water samples from other wells ranged from 6.7 to $21.3 \mu \mathrm{g} / \mathrm{L}$. The LRL for chromium ranged from $14 \mu \mathrm{g} / \mathrm{L}$ in October 1998 to $0.8 \mu \mathrm{g} / \mathrm{L}$ in October 2001; consequently, concentrations within that range were designated according to those LRLs as detections or nondetections during 1999-2001.

\section{Sodium}

During 1989-98, an average annual estimated value of 1.3 million $\mathrm{lb} / \mathrm{yr}$ of sodium in wastewater was discharged at the INL (Bartholomay and others, 1995, 1997, and 2000). During 1996-1998 about 708,000 lb/yr of sodium was discharged to the INTEC infiltration ponds; about $58,000 \mathrm{lb} / \mathrm{yr}$ was discharged to the RTC chemical-waste infiltration pond; about 524,000 lb/yr was discharged to the NRF industrial-waste ditch; and about 5,000 lb/yr was discharged at CFA (Bartholomay and others, 2000) (fig. 1). The total amount of sodium discharged at the RTC is the amount of sodium ion estimated from the sodium hydrate solution discharged (Bartholomay and others, 2000). The total amount of sodium in wastewater discharged at individual facilities from 1999 to 2001 has not been compiled.

The background concentration of sodium in water from the Snake River Plain aquifer near the INL generally is less than $10 \mathrm{mg} / \mathrm{L}$ (Robertson and others, 1974, p. 155). In October 2001, concentrations in water from most of the wells in the southern part of the INL were greater than $10 \mathrm{mg} / \mathrm{L}$. 
Concentrations of sodium in water from wells near the INTEC generally have increased slightly or remained constant since disposal practices were changed from injection to the disposal well to discharge to infiltration ponds in 1984 (fig. 3;

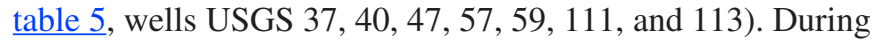
1984-98, estimated discharge rates increased slightly at the INTEC, so the increase in concentrations in water from some wells could be the result of this increase in discharge rates (Bartholomay and others, 2000). During 1999-2001, the larger concentrations of sodium were in water from wells at or near INTEC. During 2001, the largest concentration in water samples from wells at the INL was $75 \mathrm{mg} / \mathrm{L}$ in a sample from well USGS 113 (fig. 5, table 5), south of INTEC. Water from this well had the highest concentration of sodium of $99 \mathrm{mg} / \mathrm{L}$ in 1999 but concentrations decreased through 2001 (table 5). In 2001, sodium concentrations in water from wells USGS 88 and 120 (fig. 5), near the RWMC, were 44 and $32 \mathrm{mg} / \mathrm{L}$. In October 2001, water from well MTR Test at the RTC (fig. 5), contained a sodium concentration of $15 \mathrm{mg} / \mathrm{L}$, significantly less than the 1998 concentration of $42 \mu \mathrm{g} / \mathrm{L}$. Concentrations of sodium at INL during 1999-2001 generally were equal to or less than those in 1998, with the exception of well USGS 59 (table 5).

\section{Chloride}

About 2.3 million $\mathrm{lb} / \mathrm{yr}$ of chloride in wastewater was discharged to infiltration ponds at the INL during 1996-98, which was an increase from the estimated 1.5 million $\mathrm{lb} / \mathrm{yr}$ discharged during 1992-95 (Bartholomay and others, 1997, p. 36). Of the 2.3 million $\mathrm{lb} / \mathrm{yr}$ discharged during 1996-98, about 1.17 million lb/yr was discharged to the INTEC infiltration ponds (fig. 3) (Bartholomay and others, 2000), which was about the same amount discharged during 1986-95 (Orr and Cecil, 1991, p. 40; Bartholomay and others, 1995, p. 31; Bartholomay and others, 1997, p. 36). Information on the total amount of chloride discharged in wastewater during 1999-2001 has not been compiled.

The background chloride concentration in water from the Snake River Plain aquifer at the INL generally is about $15 \mathrm{mg} / \mathrm{L}$ (Robertson and others, 1974, p. 150); the ambient chloride concentration near the INTEC is about $10 \mathrm{mg} / \mathrm{L}$ and, near the CFA, about $20 \mathrm{mg} / \mathrm{L}$. In 2001, concentrations of chloride in most water samples from the INTEC and south to the CFA (fig. 14) exceeded $20 \mathrm{mg} / \mathrm{L}$.

Chloride concentrations in water from wells near the INTEC generally have increased or remained constant since disposal practices were changed from injection to the disposal well to discharge to infiltration ponds in 1984 (fig. 3; table 6, wells USGS 37, 40, 47, 57, 59, 111, and 113). Trends in concentrations in water from wells downgradient from the infiltration ponds correlated with discharge rates into the ponds when traveltime was considered. For example, chloride concentrations in water from wells USGS 57 and
37 were smallest in 1985, the year during 1984-98 in which the smallest amount of chloride was discharged into the ponds (fig. 15). Water from well USGS 37 had a smaller concentration of $27.2 \mathrm{mg} / \mathrm{L}$ in April 2001; however, disposal data are unavailable for 1999-2001. This small value may indicate decreased disposal rates at some period of time prior to collection of the sample. Concentrations in water from well USGS 37 generally correlated with discharge rates into ponds when longer traveltime was considered (fig. 15). Concentrations of chloride in water from well USGS 57 increased as discharge rates increased through 1993; concentrations then decreased through 1995, increased in 1996, and decreased again in 1997 and 1998. Concentrations continued decreasing through October 2000, and then increased through October 2001. Chloride concentrations in water from USGS 59, near the INTEC infiltration ponds, were variable during 1984-2001; concentrations were unusually large in October 1991 and 1995 (table 6). The larger concentrations probably were caused by seepage down the well from the perched ground-water zone, in which chloride concentrations in perched water wells near the infiltration ponds were about $270 \mathrm{mg} / \mathrm{L}$ in 1991 and 1995 (Bartholomay and others, 1997). In October 2001, chloride concentrations in water from wells USGS 113 and CFA 1, south of the INTEC, were 175 and $103 \mathrm{mg} / \mathrm{L}$, respectively (table 6). These concentrations were decreases from concentrations in October 1998.

In October 2001 at the RTC, the chloride concentration in water from well USGS 65 was $19 \mathrm{mg} / \mathrm{L}$. Chloride concentrations in water from all other wells completed in the Snake River Plain aquifer at or near the RTC were less than the concentration of $13.4 \mathrm{mg} / \mathrm{L}$ in water from well USGS 79. At the RWMC, chloride concentrations in water from wells USGS 88, 89, and 120 were 81, 40, and $23 \mathrm{mg} / \mathrm{L}$, respectively. Concentrations of chloride in all other wells near the RWMC were less than $19 \mathrm{mg} / \mathrm{L}$. The secondary MCL for chloride in drinking water is $250 \mathrm{mg} / \mathrm{L}$ (U.S. Environmental Protection Agency, 2001).

\section{Sulfate}

Compiled data for the amount of sulfate in wastewater discharged during 1999-2001 is unavailable. During 1996-1998, about 0.8 million lb/yr of sulfate in wastewater was discharged at the INL, which was a decrease from the 1.05 million lb/yr discharged during 1992-95 (Bartholomay and others, 2000). Of the 0.8 million $\mathrm{lb} / \mathrm{yr}$ discharged during 1996-98, about 610,000 lb/yr was discharged to infiltration ponds at the RTC; 146,000 lb/yr was discharged to infiltration ponds at the INTEC; and 45,000 lb/year was discharged to the NRF industrial-waste ditch (Bartholomay and others, 2000). The background concentrations of sulfate in the Snake River Plain aquifer in the south-central part of the INL range from about 10 to $40 \mathrm{mg} / \mathrm{L}$ (Robertson and others, 1974, p. 72). 
Table 5. Sodium concentrations in water from selected wells at and near the Central Facilities Area and the Idaho Nuclear Technology and Engineering Center, Idaho National Laboratory, Idaho, 1981-2001.

[Well No: Location of wells are shown in figures 4 and $\underline{5}$. Concentrations in picocuries per liter.

Abbreviations: USGS, U.S. Geological Survey; NS, not sampled. Symbols: -, no data, well drilled in 1984]

\begin{tabular}{|c|c|c|c|c|c|c|c|}
\hline \multicolumn{8}{|c|}{ Well No. } \\
\hline \multicolumn{2}{|c|}{ CFA 1} & \multicolumn{2}{|c|}{ USGS 37} & \multicolumn{2}{|c|}{ USGS 40} & \multicolumn{2}{|c|}{ USGS 47} \\
\hline Date & $\begin{array}{c}\text { Concen- } \\
\text { tration }\end{array}$ & Date & $\begin{array}{c}\text { Concen- } \\
\text { tration }\end{array}$ & Date & $\begin{array}{c}\text { Concen- } \\
\text { tration }\end{array}$ & Date & $\begin{array}{c}\text { Concen- } \\
\text { tration }\end{array}$ \\
\hline $10-13-81$ & 21 & $10-07-81$ & 34 & $10-12-81$ & 94 & $10-08-81$ & 21 \\
\hline $10-11-82$ & 16 & $10-07-82$ & 30 & $10-07-82$ & 69 & $10-07-82$ & 15 \\
\hline $10-06-83$ & 10 & $10-10-83$ & 37 & $10-10-83$ & 46 & $10-17-83$ & 52 \\
\hline $10-12-84$ & 14 & $10-10-84$ & 34 & $10-16-84$ & 33 & $10-23-84$ & 22 \\
\hline $10-25-85$ & 15 & $10-28-85$ & 31 & $10-29-85$ & 18 & $10-29-85$ & 18 \\
\hline $10-31-86$ & 22 & $10-27-86$ & 28 & $10-30-86$ & 15 & $10-29-86$ & 12 \\
\hline $10-15-87$ & 26 & $10-05-87$ & 33 & $10-13-87$ & 13 & $10-26-87$ & 11 \\
\hline $10-28-88$ & 15 & $10-07-88$ & 19 & $11-09-88$ & 11 & $09-30-88$ & 12 \\
\hline $10-26-89$ & 26 & 09-89 & NS & $10-18-89$ & 12 & $10-19-89$ & 13 \\
\hline $10-15-90$ & 17 & $10-17-90$ & 32 & $10-16-90$ & 14 & $10-31-90$ & 15 \\
\hline $10-10-91$ & 26 & 10-07-91 & 31 & $10-29-91$ & 16 & $10-24-91$ & 14 \\
\hline $10-08-92$ & 26 & $10-02-92$ & 38 & $11-17-92$ & 16 & $10-21-92$ & 18 \\
\hline $10-93$ & NS & $10-21-93$ & 45 & $10-08-93$ & 16 & $10-26-93$ & 15 \\
\hline $10-94$ & NS & $10-07-94$ & 46 & $10-18-94$ & 15 & $10-19-94$ & 19 \\
\hline 10-11-95 & 30 & $10-11-95$ & 41 & $10-19-95$ & 20 & $10-16-95$ & 17 \\
\hline $10-16-96$ & 18 & $10-24-96$ & 42 & $10-17-96$ & 15 & $10-21-96$ & 22 \\
\hline $10-21-97$ & 24 & $10-08-97$ & 48 & $10-20-97$ & 11 & $10-14-97$ & 19 \\
\hline $10-19-98$ & 27 & $10-15-98$ & 50 & $10-07-98$ & 12 & $10-28-98$ & 15 \\
\hline $10-20-99$ & 22 & 10-14-99 & 49 & $10-25-99$ & 10 & $10-20-99$ & 12 \\
\hline $10-11-00$ & 20 & $10-11-00$ & 46 & $10-18-00$ & 11 & $10-18-00$ & 11 \\
\hline 10-09-01 & 25 & $10-24-01$ & 38 & $10-17-01$ & 12 & $10-15-01$ & 15 \\
\hline \multicolumn{2}{|c|}{ USGS 57} & \multicolumn{2}{|c|}{ USGS 59} & \multicolumn{2}{|c|}{ USGS 111} & \multicolumn{2}{|c|}{ USGS 113} \\
\hline Date & $\begin{array}{c}\text { Concen- } \\
\text { tration }\end{array}$ & Date & $\begin{array}{c}\text { Concen- } \\
\text { tration }\end{array}$ & Date & $\begin{array}{c}\text { Concen- } \\
\text { tration }\end{array}$ & Date & $\begin{array}{c}\text { Concen- } \\
\text { tration }\end{array}$ \\
\hline $10-81$ & NS & $10-06-81$ & 19 & - & - & - & - \\
\hline $10-06-82$ & 51 & $10-06-82$ & 17 & - & - & - & - \\
\hline $10-13-83$ & 24 & $10-13-83$ & 28 & - & - & - & - \\
\hline $10-10-84$ & 45 & $10-10-84$ & 17 & - & - & - & - \\
\hline $10-29-85$ & 36 & $10-30-85$ & 45 & $11-05-85$ & 15 & $11-01-85$ & 41 \\
\hline $11-14-86$ & 28 & $11-14-86$ & 37 & $10-27-86$ & 25 & $10-27-86$ & 43 \\
\hline $10-09-87$ & 31 & $10-06-87$ & 12 & $09-25-87$ & 27 & $10-02-87$ & 49 \\
\hline $10-05-88$ & 27 & $10-21-88$ & 5 & $10-04-88$ & 28 & $09-27-88$ & 41 \\
\hline $12-22-89$ & 29 & $10-23-89$ & 12 & $10-89$ & NS & $10-89$ & NS \\
\hline $10-29-90$ & 38 & $10-12-90$ & 21 & 09-24-90 & 33 & $10-03-90$ & 71 \\
\hline $10-24-91$ & 42 & $10-21-91$ & 75 & $10-25-91$ & 22 & $10-08-91$ & 64 \\
\hline $10-06-92$ & 59 & $10-23-92$ & 36 & $10-09-92$ & 28 & $10-22-92$ & 81 \\
\hline $10-12-93$ & 72 & $10-25-93$ & 23 & $10-21-93$ & 33 & $10-23-93$ & 87 \\
\hline $10-03-94$ & 69 & $11-01-94$ & 25 & $10-13-94$ & 32 & $10-17-94$ & 90 \\
\hline $10-11-95$ & 62 & $10-23-95$ & 65 & $10-26-95$ & 23 & $10-17-95$ & 79 \\
\hline $10-18-96$ & 78 & $10-29-96$ & 38 & $10-17-96$ & 39 & $10-18-96$ & 93 \\
\hline $10-14-97$ & 78 & $10-22-97$ & 36 & $10-28-97$ & 40 & $10-16-97$ & 94 \\
\hline $10-06-98$ & 69 & $10-27-98$ & 14 & $10-26-98$ & 39 & $10-15-98$ & 96 \\
\hline $10-05-99$ & 59 & $10-06-99$ & 10 & 10-06-99 & 36 & 10-19-99 & 99 \\
\hline $10-05-00$ & 44 & $10-02-00$ & 11 & $10-03-00$ & 29 & $10-18-00$ & 80 \\
\hline $10-25-01$ & 51 & $10-18-01$ & 28 & $10-18-01$ & 26 & $10-10-01$ & 75 \\
\hline
\end{tabular}




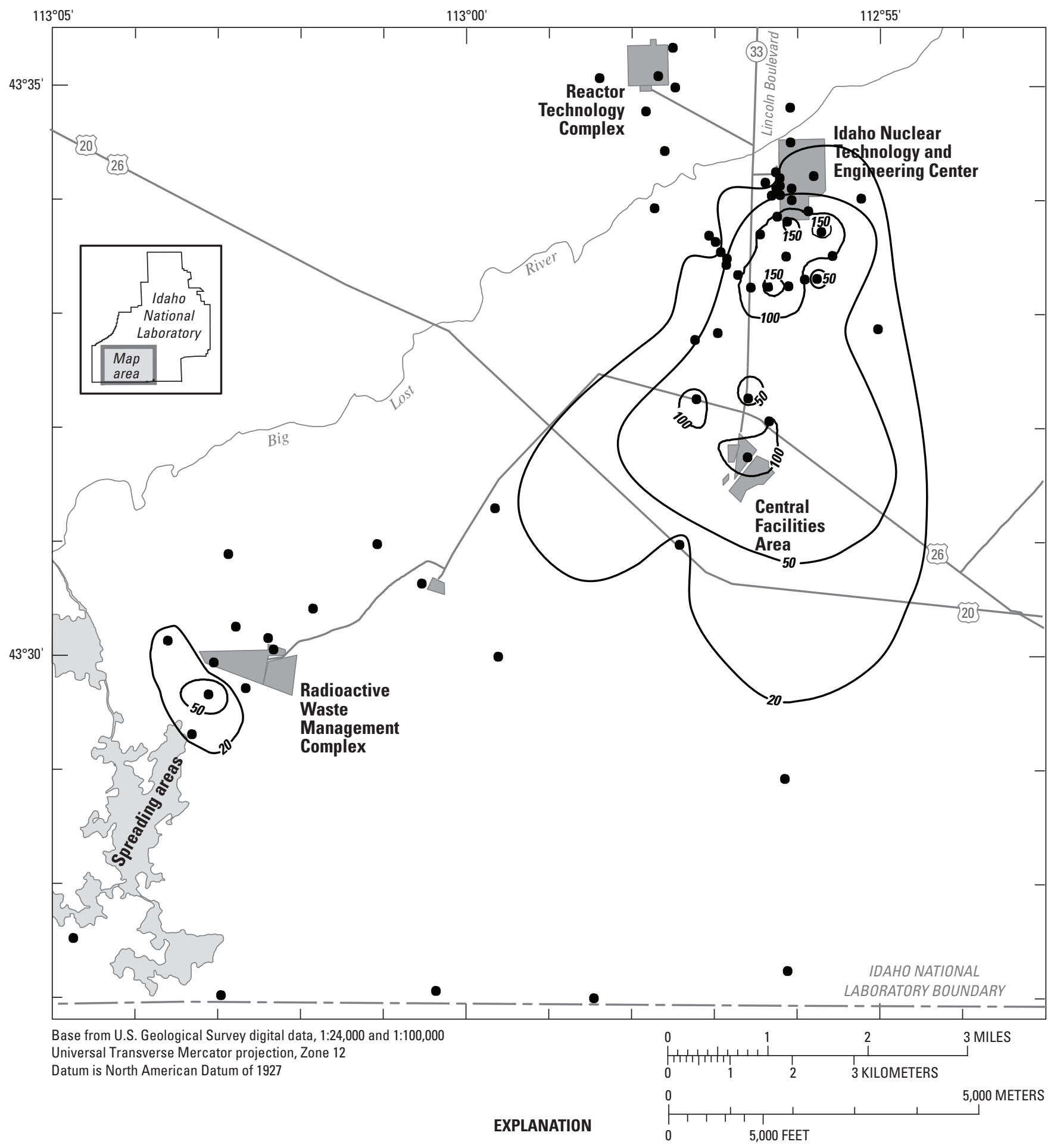

\footnotetext{
- 10 - LINE OF EQUAL CHLORIDE CONCENTRATION, October 2001-Lines of equal concentrations were interpreted from analyses of samples collected from a 3-dimensional flow system. Mapped concentrations represent samples collected from various depths in boreholes with differing well completions; for example, single- and multiplescreened intervals, and open boreholes. Location is approximate. Interval, in milligrams per liter, is variable
}

- WELL IN THE USGS WATER-QUALITY MONITORING NETWORK-Samples analyzed for chloride

Figure 14. Distribution of chloride in water from wells at and near the Reactor Technology Complex (RTC), Idaho Nuclear Technology and Engineering Center (INTEC), Central Facilities Area (CFA), and Radioactive Waste Management Complex (RWMC) at the Idaho National Laboratory (INL), Idaho, October 2001. 
Table 6. Chloride concentrations in water from selected wells at and near the Central Facilities Area and the Idaho Nuclear Technology and Engineering Center, Idaho National Laboratory, Idaho, 1980-2001.

[Well No: Locations of wells are shown in figures 4 and $\underline{5}$. Concentrations in milligrams per liter.

Abbreviations: USGS, U.S. Geological Survey; NS, not sampled. Symbols: -, no data, well drilled in 1984]

\begin{tabular}{|c|c|c|c|c|c|c|c|}
\hline \multicolumn{8}{|c|}{ Well No. } \\
\hline \multicolumn{2}{|c|}{ CFA 1} & \multicolumn{2}{|c|}{ USGS 37} & \multicolumn{2}{|c|}{ USGS 40} & \multicolumn{2}{|c|}{ USGS 47} \\
\hline Date & $\begin{array}{c}\text { Concen- } \\
\text { tration }\end{array}$ & Date & $\begin{array}{c}\text { Concen- } \\
\text { tration }\end{array}$ & Date & $\begin{array}{c}\text { Concen- } \\
\text { tration }\end{array}$ & Date & $\begin{array}{c}\text { Concen- } \\
\text { tration }\end{array}$ \\
\hline $10-21-80$ & 80 & $10-13-80$ & 72 & $10-13-80$ & 210 & $10-13-80$ & 54 \\
\hline $10-13-81$ & 82 & $10-07-81$ & 66 & $10-12-81$ & 150 & $10-08-81$ & 48 \\
\hline $10-11-82$ & 86 & $10-07-82$ & 85 & $10-07-82$ & 150 & $10-07-82$ & 32 \\
\hline $10-06-83$ & 78 & $10-10-83$ & 59 & $10-10-83$ & 150 & $10-17-83$ & 160 \\
\hline $10-12-84$ & 53 & $10-10-84$ & 53 & $10-16-84$ & 44 & $10-23-84$ & 27 \\
\hline $10-25-85$ & 51 & $10-28-85$ & 37 & $10-29-85$ & 23 & $10-29-85$ & 21 \\
\hline $10-31-86$ & 78 & $10-27-86$ & 50 & $10-30-86$ & 23 & $10-29-86$ & 23 \\
\hline $10-15-87$ & 83 & $10-05-87$ & 70 & $10-13-87$ & 24 & $10-26-87$ & 23 \\
\hline $10-28-88$ & 86 & $10-07-88$ & 86 & $11-09-88$ & 23 & $09-30-88$ & 23 \\
\hline $10-26-89$ & 93 & 09-29-89 & 92 & $10-18-89$ & 23 & $10-19-89$ & 24 \\
\hline $10-15-90$ & 86 & $10-17-90$ & 78 & $10-16-90$ & 27 & $10-31-90$ & 31 \\
\hline $10-10-91$ & 100 & $10-07-91$ & 75 & $10-29-91$ & 31 & $10-24-91$ & 30 \\
\hline $10-08-92$ & 100 & $10-02-92$ & 120 & $11-17-92$ & 29 & $10-21-92$ & 36 \\
\hline $10-93$ & NS & $10-21-93$ & 140 & $10-08-93$ & 30 & $10-26-93$ & 31 \\
\hline $10-94$ & NS & $10-07-94$ & 140 & $10-18-94$ & 30 & $10-19-94$ & 38 \\
\hline $10-11-95$ & 100 & $10-11-95$ & 100 & $10-19-95$ & 37 & $10-16-95$ & 35 \\
\hline $10-16-96$ & 70 & $10-24-96$ & 120 & $10-17-96$ & 27 & $10-21-96$ & 44 \\
\hline $10-21-97$ & 100 & $10-08-97$ & 138 & $10-20-97$ & 21 & $10-14-97$ & 38 \\
\hline 10-19-98 & 108 & $10-15-98$ & 147 & $10-07-98$ & 19 & $10-28-98$ & 26 \\
\hline $10-20-99$ & 85 & $10-14-99$ & 132 & $10-25-99$ & 16 & $10-20-99$ & 20 \\
\hline $10-11-00$ & 89 & $10-11-00$ & 103 & $10-18-00$ & 17 & $10-18-00$ & 22 \\
\hline 10-09-01 & 103 & $10-24-01$ & 79 & $10-17-01$ & 20 & $10-15-01$ & 27 \\
\hline \multicolumn{2}{|c|}{ USGS 57} & \multicolumn{2}{|c|}{ USGS 59} & \multicolumn{2}{|c|}{ USGS 111} & \multicolumn{2}{|c|}{ USGS 113} \\
\hline Date & $\begin{array}{c}\text { Concen- } \\
\text { tration }\end{array}$ & Date & $\begin{array}{c}\text { Concen- } \\
\text { tration }\end{array}$ & Date & $\begin{array}{c}\text { Concen- } \\
\text { tration }\end{array}$ & Date & $\begin{array}{c}\text { Concen- } \\
\text { tration }\end{array}$ \\
\hline $10-24-80$ & 80 & $10-24-80$ & 37 & - & - & - & - \\
\hline $10-81$ & 118 & $10-06-81$ & 37 & - & - & - & - \\
\hline $10-06-82$ & 140 & $10-06-82$ & 47 & - & - & - & - \\
\hline $10-13-83$ & 130 & $10-13-83$ & 60 & - & - & - & - \\
\hline $10-10-84$ & 64 & $10-10-84$ & 28 & - & - & - & - \\
\hline $10-29-85$ & 42 & $10-30-85$ & 40 & $11-05-85$ & 50 & $11-01-85$ & 67 \\
\hline $11-14-86$ & 64 & $11-14-86$ & 35 & $10-27-86$ & 100 & $10-27-86$ & 110 \\
\hline $10-09-87$ & 67 & $10-06-87$ & 23 & $09-24-87$ & 120 & $10-02-87$ & 150 \\
\hline $10-05-88$ & 74 & $10-21-88$ & 24 & $10-04-88$ & 120 & $09-27-88$ & 160 \\
\hline $12-22-89$ & 67 & $10-23-89$ & 22 & $10-04-89$ & 120 & $10-06-89$ & 160 \\
\hline $10-29-90$ & 85 & $10-12-90$ & 44 & $09-24-90$ & 140 & $10-03-90$ & 180 \\
\hline $10-24-91$ & 120 & $10-21-91$ & 190 & $10-25-91$ & 110 & $10-08-91$ & 170 \\
\hline $10-06-92$ & 160 & $10-23-92$ & 67 & $10-09-92$ & 130 & $10-22-92$ & 200 \\
\hline $10-12-93$ & 180 & $10-25-93$ & 44 & $10-21-93$ & 140 & $10-23-93$ & 220 \\
\hline $10-03-94$ & 170 & $11-01-94$ & 47 & $10-13-94$ & 130 & $10-17-94$ & 210 \\
\hline $10-11-95$ & 150 & $10-23-95$ & 150 & $10-26-95$ & 100 & $10-17-95$ & 190 \\
\hline $10-18-96$ & 200 & $10-29-96$ & 75 & $10-17-96$ & 160 & $10-18-96$ & 230 \\
\hline $10-14-97$ & 185 & $10-22-97$ & 71 & $10-28-97$ & 159 & $10-16-97$ & 238 \\
\hline $10-06-98$ & 161 & $10-27-98$ & 29 & $10-26-98$ & 145 & $10-15-98$ & 220 \\
\hline $10-05-99$ & 134 & $10-06-99$ & 22 & $10-06-99$ & 132 & $10-19-99$ & 204 \\
\hline $10-05-00$ & 91 & $10-02-00$ & 21 & $10-03-00$ & 98 & $10-18-00$ & 171 \\
\hline $10-25-01$ & 117 & $10-18-01$ & 66 & $10-18-01$ & 101 & $10-10-01$ & 175 \\
\hline
\end{tabular}



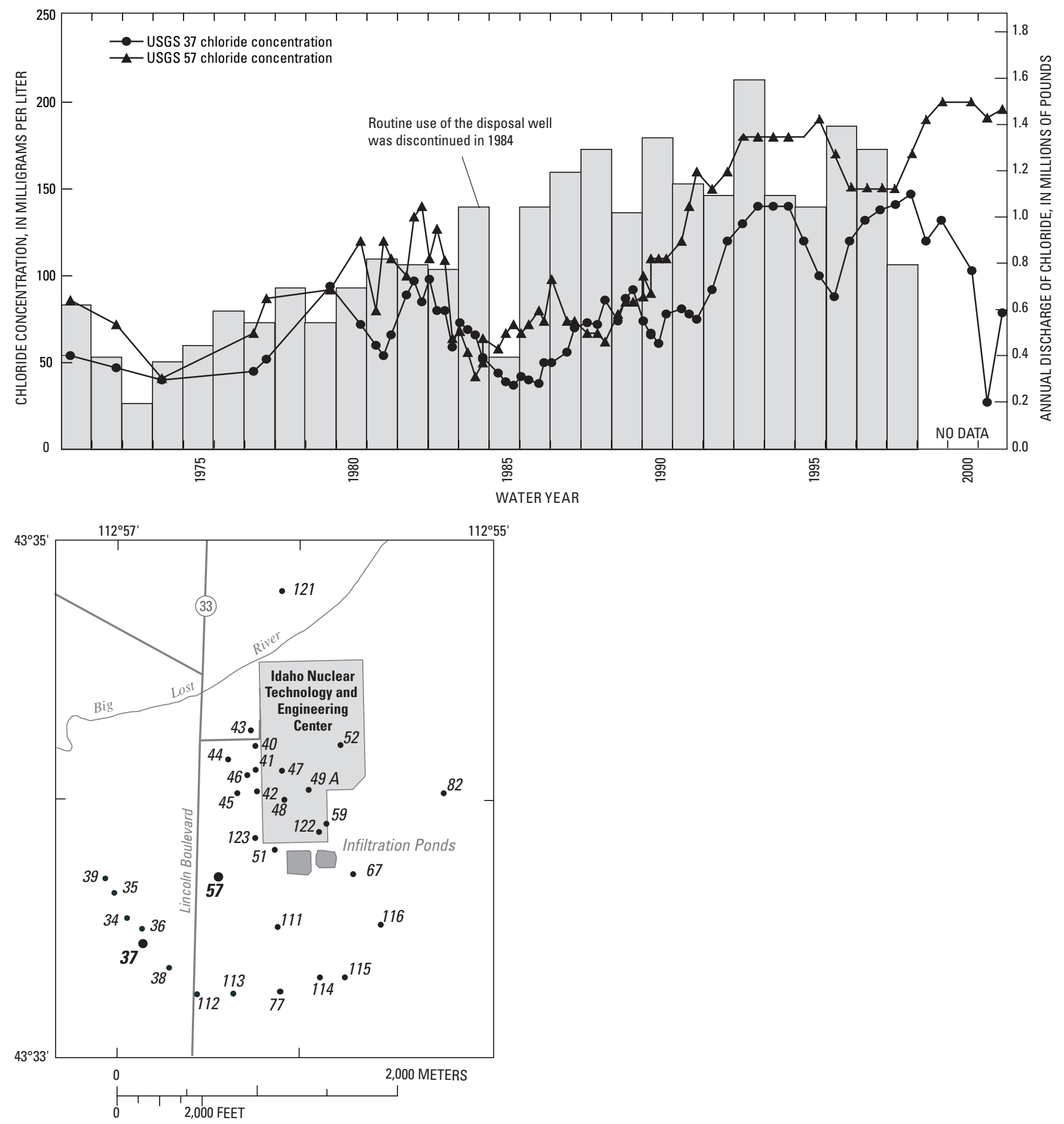

Figure 15. Amount of chloride in wastewater discharged to the disposal well and infiltration ponds at the Idaho Nuclear Technology and Engineering Center (INTEC), and the location and amount of chloride in water from wells USGS 37 and USGS 57, Idaho National Laboratory (INL), Idaho, 1971-2001. 
Because of the disposal history of sulfate at the various facilities, water-sample collection for sulfate analyses at several wells was added to the water-quality monitoring network in 1995. In 2001, sulfate concentrations in water samples from five wells in the south-central part of the INL exceeded the 40-mg/L background concentration of sulfate. Concentrations in water samples from MTR Test and USGS 65, collected in October 2001 (fig. 5) were 64 and $154 \mathrm{mg} / \mathrm{L}$, respectively, a slight increase in concentrations from samples collected in October 1998. The larger-thanbackground concentrations in water from these wells probably resulted from sulfate disposal at the RTC infiltration ponds. In October 2001, sulfate concentrations in water samples from USGS 120 and USGS 88 (fig. 5), near the RWMC, were 42 and $63 \mathrm{mg} / \mathrm{L}$, respectively. The concentration of sulfate in well USGS 120 represented a slight decrease in concentration from the October 1998 value of $53 \mathrm{mg} / \mathrm{L}$. The concentration of sulfate in well USGS 88 indicated a slight increase in concentration from the October 1998 value of $59 \mathrm{mg} / \mathrm{L}$. The larger-than-background concentration in water from these wells could have resulted from the well construction and/or waste disposal at the RWMC (Pittman and others, 1988, p. 57-61). The sulfate concentration in well CFA 2 (fig. 4), $47 \mathrm{mg} / \mathrm{L}$, also exceeded the background concentration. This was a slight increase from the October 1998 concentration of $44 \mathrm{mg} / \mathrm{L}$. The secondary MCL for sulfate in drinking water is 250 mg/L (U.S. Environmental Protection Agency, 2001).

\section{Nitrate}

Wastewater containing nitrate was injected into the Snake River Plain aquifer through the INTEC disposal well from 1952 to February 1984 and discharged to the INTEC infiltration ponds after February 1984 (Orr and Cecil, 1991). About 260,000 lb of nitrate was discharged to the INTEC infiltration ponds during 1996-98, of which 220,000 lb was discharged during February 1996 (Bartholomay and others, 2000). The average annual discharge rate during 1996-98 was about $86,700 \mathrm{lb}$, which is about 50 percent of the discharge rate during 1986-88 and 30 percent of the rate during 1979-85 (Bartholomay and others, 2000). Annual discharge rates of nitrate for 1999-2001 have not been compiled. Concentrations of nitrate in ground water not affected by wastewater disposal from INL facilities generally are less than $5 \mathrm{mg} / \mathrm{L}$ (as nitrate) (Robertson and others, 1974, p. 73).

Concentrations of nitrite plus nitrate reported by the NWQL as nitrogen in milligrams per liter have been converted to nitrate in milligrams per liter in this report. This conversion was made because (1) comparisons between concentrations given in this report and in previous reports then can be made and (2) nitrite analyses indicate that almost all the nitrite plus nitrate concentration is nitrate at and near the INL.
Nitrate concentrations at the INL have changed in response to reduced disposal rates and the transition from injection of wastewater to the INTEC disposal well to infiltration ponds in 1984. In 1981, the maximum nitrate concentration for wells near the INTEC was $62 \mathrm{mg} / \mathrm{L}$ (as nitrate) in water from well USGS 43 at the INTEC (Lewis and Jensen, 1985). By 1985, maximum concentrations in wells near the INTEC ranged from less than 5 to $27 \mathrm{mg} / \mathrm{L}$ (as nitrate) (Pittman and others, 1988, p. 61). By 1995, concentrations in wells near the INTEC ranged from less than 5 to $49 \mathrm{mg} / \mathrm{L}$ (as nitrate). In 1998, nitrate concentrations in samples from wells CFA 1, USGS 40, 43, and 77 (figs. 4 and 5 ) were $17,14,31$, and $18 \mathrm{mg} / \mathrm{L}$ (as nitrate), respectively (Bartholomay and others, 2000). The 1998 concentrations represent either a continuation of or a decrease in concentrations from those reported in 1995 (Bartholomay and others, 1997, p. 41). The decreases could have resulted from dilution by recharge from the Big Lost River and long-term decreases in discharge rates.

The original nitrate concentration calculated for a water sample collected on October 22, 2001, from well USGS 43 near the INTEC, was $91 \mathrm{mg} / \mathrm{L}$ (as nitrate). This value was verified by the NWQL, but because of the discrepancy between this concentration and historically lower concentrations in water from this well, the concentration of $21 \mathrm{mg} / \mathrm{L}$ (as nitrate), calculated for a quality assurance replicate sample collected on the same date from well USGS 43, was used in this report. In October 2001, concentrations of nitrate in water from wells USGS 40, 43, and 77 near the INTEC, and in well CFA 1 were 16, 21, 16, and $14 \mathrm{mg} / \mathrm{L}$ (as nitrate), respectively. These were generally smaller in concentration than those in 1998, with the exception of the concentration in water from well USGS 40 which had slightly increased. However, since 1981, there has been an overall decrease in nitrate concentration in water from these wells.

Historically, nitrate concentrations in water from wells near the RWMC have slightly exceeded the regional background concentration of about $5 \mathrm{mg} / \mathrm{L}$ (as nitrate) (Orr and Cecil, 1991) or 1 to $2 \mathrm{mg} / \mathrm{L}$ as nitrogen (Knobel and others, 1992). In 1998, nitrate concentrations in water samples from wells USGS 88, 89, and 119, near the RWMC, exceeded the expected background and were 7, 9, and $6 \mathrm{mg} / \mathrm{L}$, respectively (as nitrate) (Bartholomay and others, 2000). In 2001, the concentrations of nitrate in water from wells USGS 88,89 , and 119 were relatively unchanged at 7,8 , and $6 \mathrm{mg} / \mathrm{L}$ (as nitrate), respectively. Near the RTC, the concentration of nitrate in water from well USGS 65 was $8 \mathrm{mg} / \mathrm{L}$, a slight increase from the 1998 value of $7 \mathrm{mg} / \mathrm{L}$ (as nitrate). Figure 16 shows the generalized distribution of nitrate concentrations in water samples collected in October 2001. All concentrations measured in 2001 were less than the MCL for drinking water of $44 \mathrm{mg} / \mathrm{L}$ [as nitrate, or $10 \mathrm{mg} / \mathrm{L}$ as nitrogen (U.S. Environmental Protection Agency, 2001)]. 


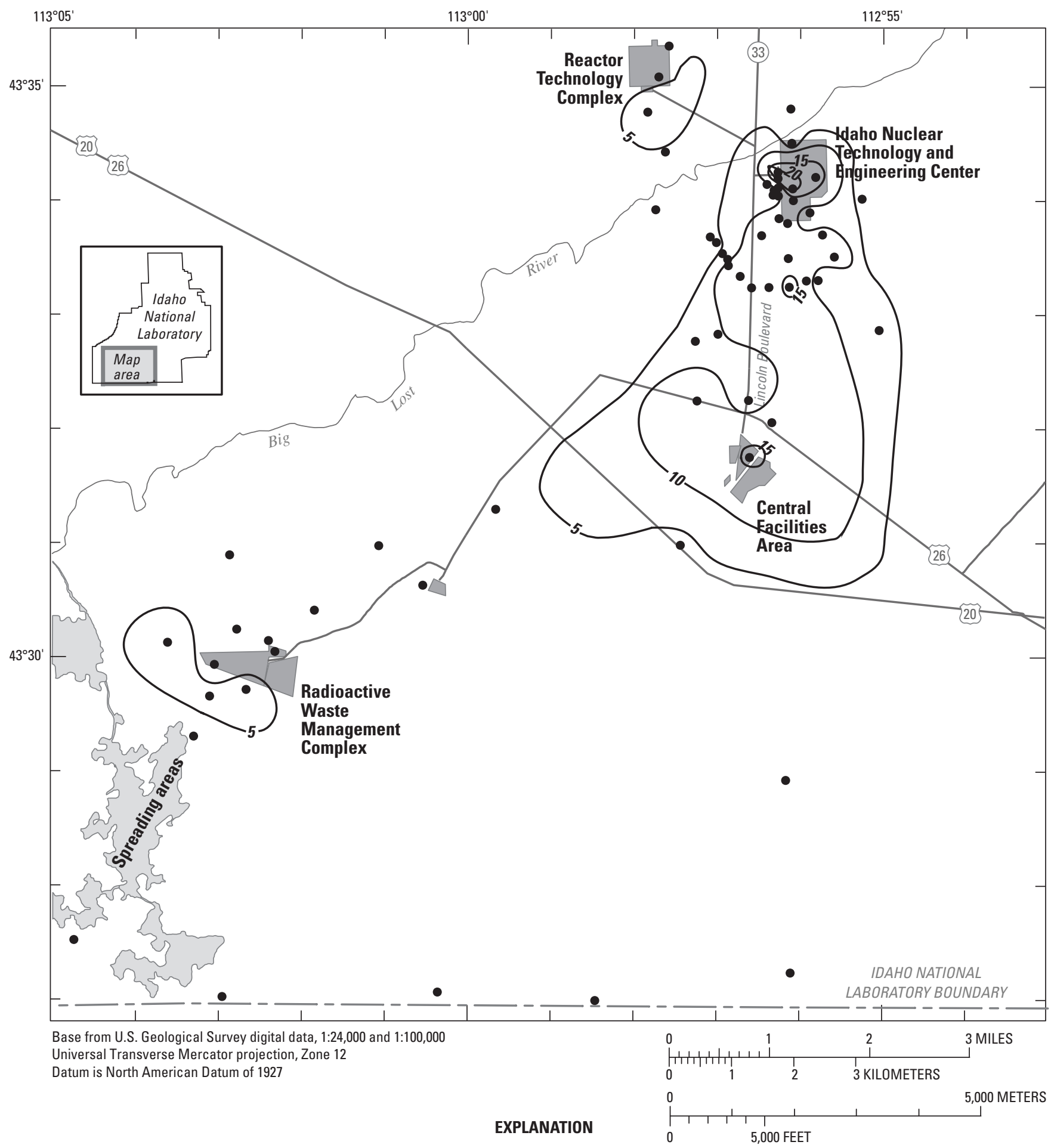

- 10 - LINE OF EQUAL NITRATE CONCENTRATION-October 2001. Lines of equal concentrations were interpreted from analyses of samples collected from a 3-dimensional flow system. Mapped concentrations represent samples collected from various depths in boreholes with differing well completions; for example, single- and multiplescreened intervals, and open boreholes. Location is approximate. Interval, in milligrams per liter as nitrate, is

- WELL IN THE USGS WATER-QUALITY MONITORING NETWORK-Samples analyzed for nitrate. variable.

Figure 16. Distribution of nitrate in water from wells at and near the Reactor Technology Complex (RTC), Idaho Nuclear Technology and Engineering Center (INTEC), Central Facilities Area (CFA), and Radioactive Waste Management Complex (RWMC) at the Idaho National Laboratory (INL), Idaho, October 2001. 


\section{Fluoride}

About 39,710 lb of fluoride in wastewater was discharged to infiltration ponds at the INTEC during 1971-98 (Bartholomay and others, 2000). The background concentrations of fluoride in the Snake River Plain aquifer in the southwestern part of the INL range from about 0.1 to $0.3 \mathrm{mg} / \mathrm{L}$ (Robertson and others, 1974, p. 75). Amounts of fluoride discharged since 1998 have not been compiled.

As part of the INL ground-water monitoring program adopted in 1994, the USGS began analyzing samples collected near the INTEC for concentrations of fluoride. During 1999-2001, water samples from 12 wells were analyzed for fluoride; detected concentrations ranged from 0.2 to $0.3 \mathrm{mg} / \mathrm{L}$. These concentrations are similar to the background concentrations reported by Robertson and others (1974), which indicates that wastewater disposal has not had an appreciable affect on fluoride concentrations in the Snake River Plain aquifer near the INTEC. The LRL for fluoride was set at $0.16 \mathrm{mg} / \mathrm{L}$ beginning October 16,2000 , and changed to $0.11 \mathrm{mg} / \mathrm{L}$ on October 1, 2001. The previous MRL was $0.1 \mathrm{mg} / \mathrm{L}$.

\section{Trace Elements}

As part of the INL ground-water monitoring program adopted in 1994 and several special sampling programs, water samples from several wells were collected and analyzed for various trace elements during 1999-2001. These trace elements were aluminum, antimony, arsenic, barium, beryllium, cadmium, cobalt, copper, iron, lead, lithium, manganese, mercury, molybdenum, nickel, selenium, silver, strontium, thallium, uranium, vanadium, and zinc. A summary of background concentrations of selected constituents in Snake River Plain aquifer water samples is presented in Knobel and others (1992, p. 52). Because the amounts of each constituent in wastewater discharged from INL facilities have not been compiled annually from monitoring data since 1998, these amounts are unavailable for 1999-2001.

Beginning in 1998, the NWQL began implementing new reporting procedures based on LT-MDLs for some analytical methods (Childress and others, 1999). This change in LRLs (as opposed to MRLs) for some elements accounts for concentrations of some elements being detected during 1999-2001, although historically the concentrations were less than the MRL. A summary of concentration ranges in water samples analyzed for each trace element during 1999-2001 by the USGS follows.

Aluminum-About $117 \mathrm{lb}$ of aluminum in wastewater was discharged at the INTEC during 1995-98. There are no other recorded discharges of aluminum at the INL during 1971-98 (Bartholomay and others, 2000). During 1999-2001, water samples from 17 wells completed in the Snake River
Plain aquifer at the INL were analyzed for aluminum; concentrations ranged from 1 to $18 \mu \mathrm{g} / \mathrm{L}$. The MRL for aluminum during this period was 1 or $10 \mu \mathrm{g} / \mathrm{L}$; a new LRL was not set.

Antimony - There are no recorded discharges of antimony in wastewater at the INL (Bartholomay and others, 2000). During 1996-98, water samples from nine wells completed in the Snake River Plain aquifer at the INL were analyzed for antimony; concentrations in all samples were less than the MRL of $1 \mu \mathrm{g} / \mathrm{L}$ (Bartholomay and others, 2000). The LRL for antimony was changed to $0.048 \mu \mathrm{g} / \mathrm{L}$ beginning October 1, 2000. Detected concentrations of antimony in water samples from nine wells after October 1, 2000, ranged from 0.09 to $0.24 \mu \mathrm{g} / \mathrm{L}$. Concentrations reported in samples analyzed prior to the change in reporting conventions were all less than the MRL of $1 \mu \mathrm{g} / \mathrm{L}$.

Arsenic - About $11 \mathrm{lb}$ of arsenic in wastewater was discharged at the INL during 1971-98 (Bartholomay and others, 2000). During 1999-2001, water samples from 17 wells completed in the Snake River Plain aquifer at the INL were analyzed for arsenic; detected concentrations ranged from less than 1 to $3.7 \mu \mathrm{g} / \mathrm{L}$. The LRL for arsenic was set at $2 \mu \mathrm{g} / \mathrm{L}$ beginning October 1, 1999. The previous MRL was $1 \mu \mathrm{g} / \mathrm{L}$.

Barium-About 4,740 lb of barium in wastewater was discharged at the INL during 1971-98 (Bartholomay and others, 2000). During 1999-2001, water samples from 17 wells completed in the Snake River Plain aquifer at the INL were analyzed for barium; detected concentrations ranged from 16 to $142 \mu \mathrm{g} / \mathrm{L}$. The MRL for barium of $1 \mu \mathrm{g} / \mathrm{L}$ did not change.

Beryllium-Less than $1 \mathrm{lb}$ of beryllium in wastewater was discharged at the INL during 1971-98 (Bartholomay and others, 2000). During 1999-2001, water samples from nine wells completed in the Snake River Plain aquifer at the INL were analyzed for beryllium; all concentrations were less than the LRL of $0.06 \mu \mathrm{g} / \mathrm{L}$ implemented October 1, 2000. The previous MRL was $1 \mu \mathrm{g} / \mathrm{L}$.

Cadmium-About $22 \mathrm{lb}$ of cadmium was discharged in wastewater at the INL during 1971-98 (Bartholomay and others, 2000). During 1999-2001, water samples from nine wells completed in the Snake River Plain aquifer at the INL were analyzed for cadmium; detected concentrations ranged from 0.04 to $0.19 \mu \mathrm{g} / \mathrm{L}$. The LRL for cadmium was set at $0.037 \mu \mathrm{g} / \mathrm{L}$ beginning October 1, 2000. The previous MRL was $1 \mu \mathrm{g} / \mathrm{L}$.

Cobalt-No discharges of cobalt in wastewater are recorded at the INL (Bartholomay and others, 2000). During 1999-2001, water samples from nine wells completed in the Snake River Plain aquifer at the INL were analyzed for cobalt; detected concentrations ranged from 0.04 to $0.25 \mu \mathrm{g} / \mathrm{L}$. The LRL for cobalt was set at $0.015 \mu \mathrm{g} / \mathrm{L}$ beginning October 1 , 2000. The previous MRL was $1 \mu \mathrm{g} / \mathrm{L}$. 
Copper-About $81 \mathrm{lb}$ of copper in wastewater was discharged at the INTEC during 1995-98. There are no other recorded discharges at the INL during 1971-98 (Bartholomay and others, 2000). During 1999-2001, water samples from nine wells completed in the Snake River Plain aquifer at the INL were analyzed for copper; detected concentrations ranged from 0.23 to $2.2 \mu \mathrm{g} / \mathrm{L}$. The LRL for copper was set at $0.23 \mu \mathrm{g} / \mathrm{L}$ beginning October 1, 2000. The previous MRL was $1 \mu \mathrm{g} / \mathrm{L}$.

Iron-About $752 \mathrm{lb}$ of iron in wastewater was discharged at the INTEC during 1995-98. There are no other recorded discharges at the INL during 1971-98 (Bartholomay and others, 2000). During 1999-2001, water samples from eight wells completed in the Snake River Plain aquifer at the INL were analyzed for iron; detected concentrations ranged 12 to $50 \mu \mathrm{g} / \mathrm{L}$. The LRL for iron was set at $10 \mu \mathrm{g} / \mathrm{L}$ beginning October 1, 1998. The previous MRL also was $10 \mu \mathrm{g} / \mathrm{L}$.

Lead-About $556 \mathrm{lb}$ of lead in wastewater was discharged at the INL during 1971-98 (Bartholomay and others, 2000). During 1999-2001, water samples from 17 wells completed in the Snake River Plain aquifer at the INL were analyzed for lead; detected concentrations ranged from 0.1 to $13 \mu \mathrm{g} / \mathrm{L}$. The LRL for lead was set at $0.08 \mu \mathrm{g} / \mathrm{L}$ beginning October 1, 2000. The previous MRL was $1 \mu \mathrm{g} / \mathrm{L}$.

Lithium-No discharges of lithium in wastewater are recorded at the INL (Bartholomay and others, 2000). During 1999-2001, water samples from eight wells completed in the Snake River Plain aquifer at the INL were analyzed for lithium; detected concentrations ranged from 4.6 to $5.5 \mu \mathrm{g} / \mathrm{L}$. The LRL for lithium was set at $0.3 \mu \mathrm{g} / \mathrm{L}$ beginning October 1, 2000. The previous MRL also was $0.3 \mu \mathrm{g} / \mathrm{L}$.

Manganese-About $44 \mathrm{lb}$ of manganese in wastewater was discharged at the INTEC during 1995-98. There were no other recorded discharges of manganese at the INL during 1971-98 (Bartholomay and others, 2000). During 1999-2001, water samples from 17 wells completed in the Snake River Plain aquifer at the INL were analyzed for manganese; detected concentrations ranged from less than 0.16 to $10.5 \mu \mathrm{g} / \mathrm{L}$. The LRL for manganese was set at $0.1 \mu \mathrm{g} / \mathrm{L}$ beginning October 1, 2000. MRLs used during 1999-2000 for manganese were $1,2,2.2$, or $3.2 \mu \mathrm{g} / \mathrm{L}$.

Mercury-About $141 \mathrm{lb}$ of mercury in wastewater was discharged at the INL during 1971-98 (Bartholomay and others, 2000). During 1999-2001, water samples from 24 wells completed in the Snake River Plain aquifer at the INL were analyzed for mercury; detected concentrations ranged from 0.51 to $0.53 \mu \mathrm{g} / \mathrm{L}$. The LRL for mercury was set at $0.011 \mu \mathrm{g} / \mathrm{L}$ beginning October 1, 2001. MRLs used during 1999-2001 were $0.23,0.1$, and $0.01 \mu \mathrm{g} / \mathrm{L}$.

Molybdenum - No discharges of molybdenum in wastewater are recorded at the INL (Bartholomay and others, 2000). During 1999-2001, water samples from 17 wells completed in the Snake River Plain aquifer at the INL were analyzed for molybdenum; detected concentrations ranged from 1 to $6 \mu \mathrm{g} / \mathrm{L}$. The LRL for molybdenum was set at $0.2 \mu \mathrm{g} / \mathrm{L}$ beginning October 1, 2000. The previous MRL was $1 \mu \mathrm{g} / \mathrm{L}$.
Nickel-No discharges of nickel in wastewater are recorded at the INL (Bartholomay and others, 2000). During 1999-2001, water samples from nine wells completed in the Snake River Plain aquifer at the INL were analyzed for nickel; detected concentrations ranged from 0.15 to $3 \mu \mathrm{g} / \mathrm{L}$. The LRL for nickel was set at $0.06 \mu \mathrm{g} / \mathrm{L}$ beginning October 1, 2000. The previous MRL was $1 \mu \mathrm{g} / \mathrm{L}$.

Selenium-About $9 \mathrm{lb}$ of selenium in wastewater was discharged at the INL during 1971-98 (Bartholomay and others, 2000). During 1999-2001, water samples from six wells completed in the Snake River Plain aquifer at the INL were analyzed for selenium; detected concentrations ranged from 1.2 to $2.6 \mu \mathrm{g} / \mathrm{L}$. The LRL for selenium was set at $2.4 \mu \mathrm{g} / \mathrm{L}$ beginning October 1, 1999. The previous MRL was $1 \mu \mathrm{g} / \mathrm{L}$.

Silver-About $190 \mathrm{lb}$ of silver in wastewater was discharged at the INL during 1971-98 (Bartholomay and others, 2000). During 1999-2001, water samples from nine wells completed in the Snake River Plain aquifer at the INL were analyzed for silver; concentrations were less than $1 \mu \mathrm{g} / \mathrm{L}$. The MRL for silver did not change.

Strontium-No discharges of stable strontium isotopes in wastewater are recorded at the INL (Bartholomay and others, 2000). During 1999-2001, water samples from eight wells completed in the Snake River Plain aquifer at the INL were analyzed for stable strontium; detected concentrations ranged from 150 to $315 \mu \mathrm{g} / \mathrm{L}$. The LRL for strontium was set at $0.08 \mu \mathrm{g} / \mathrm{L}$ beginning October 1,2000 . The previous MRL was $0.2 \mu \mathrm{g} / \mathrm{L}$.

Thallium-No discharges of thallium in wastewater are recorded at the INL (Bartholomay and others, 2000). During 1999-2001, water samples from five wells completed in the Snake River Plain aquifer at the INL were analyzed for thallium; all concentrations were less than the LRL of $0.04 \mu \mathrm{g} / \mathrm{L}$ implemented October 1, 2000, and the previous MRL of $0.5 \mu \mathrm{g} / \mathrm{L}$.

Uranium-No discharges of uranium in wastewater are recorded at the INL (Bartholomay and others, 2000). During 1999-2001, water samples from nine wells completed in the Snake River Plain aquifer at the INL were analyzed for uranium; detected concentrations ranged from 1.4 to $2.6 \mu \mathrm{g} / \mathrm{L}$. The LRL for uranium was set at $0.018 \mu \mathrm{g} / \mathrm{L}$ beginning October 1, 2000. The previous MRL was $1 \mu \mathrm{g} / \mathrm{L}$.

Vanadium - No discharges of vanadium in wastewater are recorded at the INL (Bartholomay and others, 2000). During 1999-2001, water samples from six wells completed in the Snake River Plain aquifer at the INL were analyzed for vanadium; detected concentrations ranged from 3.6 to $14.1 \mu \mathrm{g} / \mathrm{L}$. The LRL for vanadium was set at $0.2 \mu \mathrm{g} / \mathrm{L}$ beginning October 1, 2000. The previous MRL was $1 \mu \mathrm{g} / \mathrm{L}$.

Zinc-About 5,240 lb of zinc in wastewater was discharged at the INL during 1971-98 (Bartholomay and others, 2000). During 1999-2001, water samples from 17 wells completed in the Snake River Plain aquifer at the INL were analyzed for zinc; detected concentrations ranged from 1.4 to $554 \mu \mathrm{g} / \mathrm{L}$. The MRL of $1 \mu \mathrm{g} / \mathrm{L}$ did not change. 


\section{Purgeable Organic Compounds}

Purgeable organic compounds (POCs) are present in the Snake River Plain aquifer because of waste-disposal practices at the INL. In 1987, water samples from 81 wells completed in the Snake River Plain aquifer at and near the INL were analyzed for 36 POCs as part of a reconnaissance sampling program (Mann and Knobel, 1987). Analyses indicated that concentrations of from 1 to 12 POCs in samples from 45 wells exceeded their reporting levels. The prevalent compounds were trichloroethylene, 1,1,1-trichloroethane, toluene, tetrachloroethylene, carbon tetrachloride, chloroform, 1,1, dichloroethylene, and dichlorodifluoromethane. In 1988 and 1989, water samples were collected from 38 wells as a continuation of the 1987 study (Mann, 1990). Concentrations of from 1 to 19 POCs, primarily carbon tetrachloride, 1,1,1-trichloroethane, and trichloroethylene, in water samples from 22 wells exceeded the MRLs. In 1990 and 1991, water samples were collected from 76 wells for various waterquality studies at or near the INL (Liszewski and Mann, 1992). Concentrations of from 1 to 14 POCs, primarily carbon tetrachloride, 1,1,1-trichloroethane, and trichloroethylene, in water samples from 31 of these wells exceeded the MRLs. During 1992-95, water samples were collected from 54 wells at or near the INL for various water-quality studies (Greene and Tucker, 1998). Concentrations of from 1 to 14 POCs, primarily carbon tetrachloride, 1,1,1-trichloroethane, trichloroethylene, and chloroform, in water samples from 23 of these wells exceeded the MRLs. During 1996-98, water samples were collected from 44 wells at or near the INL for various water-quality studies. Concentrations of from 1 to 12 POCs, primarily carbon tetrachloride, 1,1,1-trichloroethane, trichloroethylene, chloroform, and tetrachloroethylene, in water samples from 15 of these wells exceeded the MRLs (Bartholomay and others, 2000).

During 1999-2001, water samples from 36 wells at and near the INL were analyzed for POCS. Ten POCs were detected. Concentrations of from 1 to 5 POCs, primarily carbon tetrachloride, 1,1,1-trichloroethane, trichloroethylene, chloroform, and tetrachloroethylene, in water samples from 17 of these wells exceeded the MRLs. The MRL for some POCs was changed from 0.2 to $0.1 \mu \mathrm{g} / \mathrm{L}$ during $1998-2001$, a change that resulted in detections of smaller concentrations than in previous years.

A plume of 1,1,1-trichloroethane, a solvent used in industrial cleaning processes (Lucius and others, 1989, p. 450), has developed in the Snake River Plain aquifer near the INTEC because of waste-disposal practices (Bartholomay and others, 1995). During 1992-95, water samples were collected from 10 of the wells near the INTEC that previously had water containing concentrations of 1,1,1-trichloroethane exceeding the MRL. Concentrations in water from 8 of the 10 wells still exceeded the MRL (Bartholomay and others, 1997). Water samples from three of the wells near INTEC that previously had water containing concentrations of 1,1,1- trichloroethane exceeding the MRL were collected during 1996-98, and concentrations in water from all three of the wells exceeded the MRL.
During October 2001, concentrations of 1,1,1-trichloroethane in water from wells USGS 34, 38, and 77, and a newer well, USGS 128, south of the INTEC, exceeded the MRL. The concentrations in water from wells USGS 34 and 77 were 0.14 and $0.22 \mu \mathrm{g} / \mathrm{L}$, respectively. The concentrations in water in wells USGS 38 and 128 were 0.15 and $0.16 \mu \mathrm{g} / \mathrm{L}$, respectively. The detection of these concentrations resulted from the lowering of the MRL from 0.2 to $0.1 \mu \mathrm{g} / \mathrm{L}$ effective October 1, 1998. All 1,1,1-trichloroethane concentrations were less than the MCL for drinking water of $200 \mu \mathrm{g} / \mathrm{L}$ (U.S. Environmental Protection Agency, 2001). Concentrations of 0.14 and $0.12 \mu \mathrm{g} / \mathrm{L}$ of 1,1 dichloroethylene also were detected in 2001 in two samples from well USGS 77. The detection of these concentrations resulted from the change in the MRL from 0.2 to $0.1 \mu \mathrm{g} / \mathrm{L}$ effective May 12, 2001.

During 1996-98, concentrations of POCs in water samples from several wells at and near the RWMC exceeded the reporting levels (Bartholomay and others, 2000). For example, in October 1998, water from the RWMC Production well contained $4.5 \mu \mathrm{g} / \mathrm{L}$ of carbon tetrachloride, $0.8 \mu \mathrm{g} / \mathrm{L}$ of chloroform, $0.5 \mu \mathrm{g} / \mathrm{L}$ of 1,1,1-trichloroethane, $2.1 \mu \mathrm{g} / \mathrm{L}$ of trichloroethylene, and $0.18 \mu \mathrm{g} / \mathrm{L}$ of tetrachloroethylene (Bartholomay and others, 2000). In October 2001, water from the RWMC Production well yielded detections for the same POCs, however, all concentrations had decreased from those of October 1998. Reported concentrations were $3.6 \mu \mathrm{g} / \mathrm{L}$ of carbon tetrachloride, $0.5 \mu \mathrm{g} / \mathrm{L}$ of chloroform, $0.4 \mu \mathrm{g} / \mathrm{L}$ of 1,1,1-trichloroethane, $1.6 \mu \mathrm{g} / \mathrm{L}$ of trichloroethylene, and $0.17 \mu \mathrm{g} / \mathrm{L}$ of tetrachloroethylene.

A plot of carbon tetrachloride concentrations in water from the RWMC Production well (fig. 17) indicates that concentration trends have generally increased with time, although the October 2001 sample concentration was slightly less than the October 1998 concentration. In October 2001, concentrations of carbon tetrachloride, 1,1,1-trichloroethane, trichloroethylene, and chloroform in water from well USGS 87 (fig. 5) exceeded the reporting levels. The detection of chloroform in 2001 and not in 1998 could have resulted from the lowering of the MRL for chloroform from 0.2 to $0.1 \mu \mathrm{g} / \mathrm{L}$ on October 1, 1998. Concentrations of chloroform and trichloroethylene and estimated values of carbon tetrachloride and 1,1,1-trichloroethane in water from well USGS 88 (fig. 5) also exceeded the reporting levels in October 2001. The concentrations for chloroform and trichloroethylene were the same or slightly less than October 1998 concentrations. Concentrations of carbon tetrachloride, chloroform, tetrachloroethylene, 1,1,1-trichloroethane, and trichloroethylene in water from well USGS 120 (fig. 5) exceeded the reporting level; concentrations were the same or slightly less than October 1998 concentrations. Concentrations of carbon tetrachloride, 1,1,1-trichloroethane, trichloroethylene, chloroform, and tetrachloroethylene in a September 2001 sample from well RWMC M7S (fig. 3) exceeded the MRLs. 


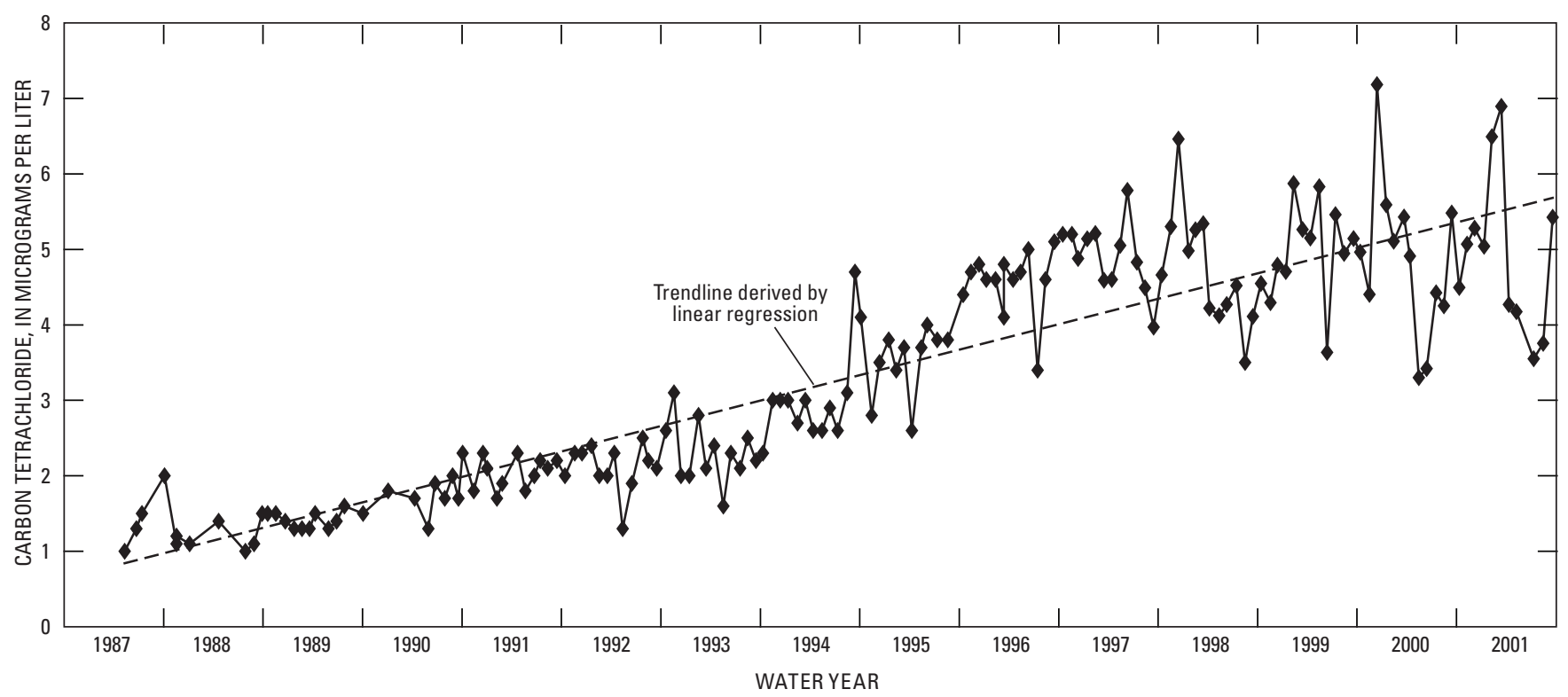

Figure 17. Carbon tetrachloride concentrations in water from the Radioactive Waste Management Complex (RWMC) production well, Idaho National Laboratory (INL), Idaho, 1987-2001.

During 1987-89, concentrations of from 1 to 15 POCs in water from 10 wells near the TAN exceeded their reporting levels (Mann and Knobel, 1987; Mann, 1990). Water samples from TAN wells were not collected by the USGS during 1990-93 because the wells were not part of routine sampling. During 1994-95, samples from six wells near the TAN were collected and analyzed as part of the INL ground-water monitoring program (Sehlke and Bickford, 1993). One sample from the well No Name 1 (formerly called TAN Expl. Well; fig. 2) contained $1.1 \mu \mathrm{g} / \mathrm{L}$ of isopropylbenzene. One sample from well ANP 9 (fig. 2) contained $11 \mu \mathrm{g} / \mathrm{L}$ of toluene (Bartholomay and others, 1997). During 1996-98, samples were collected from five wells near TAN as part of the USGS ground-water monitoring program. No POC concentrations exceeded their reporting levels. In addition, water from well USGS 24 (fig. 2) was analyzed in 1996 and concentrations of nine POCs exceeded their reporting levels. Concentrations of two of these POCs, $990 \mu \mathrm{g} / \mathrm{L}$ of trichloroethylene and $46 \mu \mathrm{g} / \mathrm{L}$ of tetrachloroethylene, exceeded their respective MCLs of $5 \mu \mathrm{g} / \mathrm{L}$ for drinking water (U.S. Environmental Protection Agency, 1998) (Bartholomay and others, 2000). During 1999-2001, water samples from three wells near TAN (ANP 9, No Name 1, and PSTF Test) (fig. 2) were sampled for POCs. Concentrations of POCs in water from these wells were all less than the MRL.

\section{Total Organic Carbon}

Analyses of total organic carbon (TOC) are used to screen for organic compounds in the aquifer as a general indicator of ground-water contamination. As part of the INL ground-water monitoring program adopted in 1994, the USGS began collecting and analyzing water from several wells at the INL for TOC. During September-October 2001, water samples from 22 wells completed in the Snake River Plain aquifer at the INL were analyzed for TOC; detected concentrations ranged from 0.6 to $3.1 \mathrm{mg} / \mathrm{L}$. The LRL for TOC was set at $0.27 \mathrm{mg} / \mathrm{L}$ beginning October 1,1999 , and revised to $0.6 \mathrm{mg} / \mathrm{L}$ beginning October 20, 2000. The previous MRL was $0.1 \mathrm{mg} / \mathrm{L}$.

\section{Specific Conductance, Temperature, and pH}

Specific conductance is a measure of the electrical conductivity of water and is proportional to the quantities of dissolved chemical constituents in the water. Dissolved chemical constituents such as chloride, sodium, and sulfate in wastewater discharged to disposal wells and infiltration ponds at INL facilities generally have increased the specific conductance of ground water through time.

The general increase in specific conductance in ground water attributed to wastewater discharged to the aquifer since the mid-1980s is apparent in ground water downgradient from INL facilities. A plume of increased specific conductance originated from the INTEC infiltration ponds and extended downgradient from the INTEC to the CFA (fig. 18). The specific conductance of water from several wells within this plume had increased from about $500 \mu \mathrm{S} / \mathrm{cm}$ in 1985 (Pittman and others, 1988, p. 64) to more than $1,000 \mu \mathrm{S} / \mathrm{cm}$ in 1998 but then decreased to about $960 \mu \mathrm{S} / \mathrm{cm}$ by 2001 in water from well USGS 51. Specific conductance of water from well USGS 113 (fig. 5) was 1,080 $\mu \mathrm{S} / \mathrm{cm}$ in October 1998, and then decreased to $937 \mu \mathrm{S} / \mathrm{cm}$ in October 2001. 


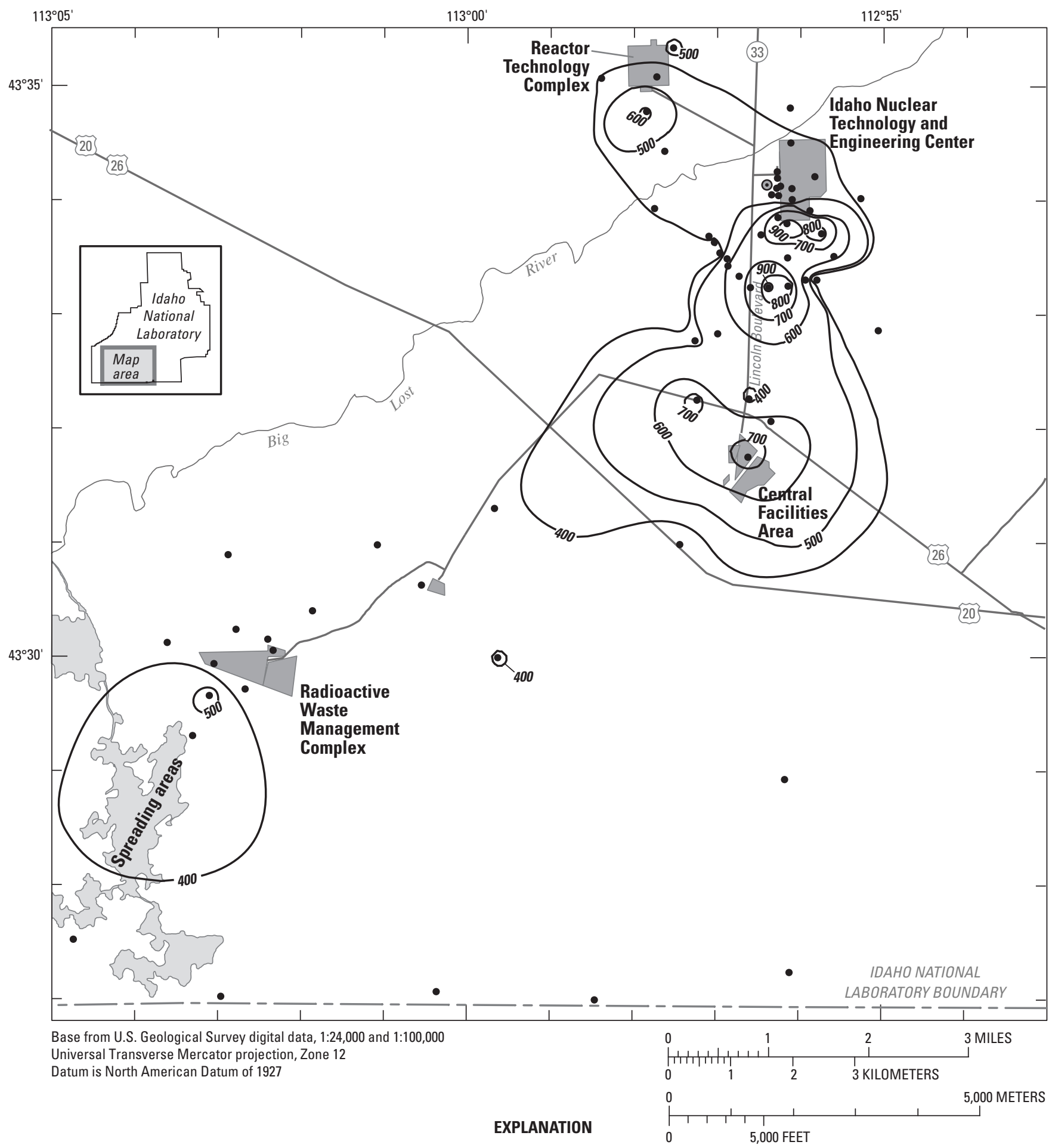

-10- LINE OF EQUAL SPECIFIC CONDUCTANCE MEASUREMENTS - October 2001. Lines of equal specific conductance were interpreted from field measurements of samples collected from a 3-dimensional flow system. Mapped concentrations represent samples collected from various depths in boreholes with differing well completions; for example, single- and multiple-screened intervals, and open boreholes. Location is approximate. Interval, in microsiemens per centimeter, is variable
- WELL IN THE USGS WATER-QUALITY MONITORING NETWORK-Samples measured for specific conductance

$\odot$ Well value less than line of equal measurement

Figure 18. Distribution of specific conductance of water from wells at and near the Reactor Technology Complex (RTC), Idaho Nuclear Technology and Engineering Center (INTEC), Central Facilities Area (CFA), and Radioactive Waste Management Complex (RWMC) at the Idaho National Laboratory (INL), Idaho, October 2001. 
The specific conductance of water from several wells at the RTC exceeded $400 \mu \mathrm{S} / \mathrm{cm}$ in 2001. Specific conductance of water from well USGS 65 (fig. 5), downgradient from the infiltration ponds at the RTC, was $628 \mu \mathrm{S} / \mathrm{cm}$ in October 2001. Maximum specific conductance of water from wells USGS 88 and 120 (fig. 5), near the RWMC, were 581 and $452 \mu \mathrm{S} / \mathrm{cm}$, respectively, in October 2001.

In 1999, the specific conductance of water from 121 wells ranged from 273 to $1,070 \mu \mathrm{S} / \mathrm{cm}$; the median specific conductance was $405 \mu \mathrm{S} / \mathrm{cm}$. In 2000, the specific conductance of water from 127 wells ranged from 260 to $991 \mu \mathrm{S} / \mathrm{cm}$; the median specific conductance was $404 \mu \mathrm{S} / \mathrm{cm}$. In 2001, the specific conductance of water from 126 wells at the INL ranged from 262 to $960 \mu \mathrm{S} / \mathrm{cm}$; the median specific conductance was $402 \mu \mathrm{S} / \mathrm{cm}$.

During each year, 1999-2001, water temperature and $\mathrm{pH}$ were measured in water from 121, 127, and 126 wells at the INL, respectively. Well P\&W 2 (fig. 4) consistently had the lowest water temperatures ranging from 7.6 to $8.2^{\circ} \mathrm{C}$. Well USGS 22 consistently had the highest water temperatures, ranging from 19.5 to $20.1^{\circ} \mathrm{C}$. The median water temperature for all wells sampled was $13.0^{\circ} \mathrm{C}$ in each year, 1999-2001, a slight increase from 1998. In 1999, the $\mathrm{pH}$ ranged from 7.4 in well USGS 57 to 8.5 in well USGS 119 (fig. 3). In 2000, the $\mathrm{pH}$ ranged from 7.4 in water from well USGS 39 to 8.8 in water from well USGS 51 (fig. 3). In 2001, the $\mathrm{pH}$ ranged from 7.5 in water from wells Highway 3 (fig. 4) and TRA 4 (fig. 5) to 8.4 in water from well USGS 88 (fig. 5). The median $\mathrm{pH}$ in water from all wells was 8.0 in each year, 1999-2001, the same as in 1998.

\section{Summary}

Radiochemical and chemical wastewater discharged since 1952 to infiltration ponds and disposal wells at the Idaho National Laboratory (INL) has affected water quality in the Snake River Plain aquifer. The U.S. Geological Survey, in cooperation with the U.S. Department of Energy, maintains ground-water monitoring networks at the INL to determine hydrologic trends and to delineate the movement of radiochemical and chemical wastes in the aquifer. This report presents an analysis of water-level and water-quality data collected from the wells in the USGS monitoring networks during 1999-2001.

Water in the Snake River Plain aquifer moves principally through fractures and interflow zones in basalt, generally flows southwestward, and eventually discharges at springs along the Snake River. The aquifer is recharged principally from infiltration of irrigation water, infiltration of streamflow, ground-water inflow from adjoining mountain drainage basins, and infiltration of precipitation.
In 2001, the altitude of the water table in the Snake River Plain aquifer at the INL was about 4,600 feet in the northern part and about 4,420 feet in the southwestern part. Water flowed southward and southwestward beneath the INL (fig. 9) at an average hydraulic gradient of about 4 feet per mile. From March-May 1998 to March-May 2001, water levels in INL wells increased in some areas and decreased in other areas. Increases ranged from about 3 feet in wells in the west-central part of the INL to about 1 foot in the northern part. Decreases ranged from 1 to 4 feet in the southwestern part of the INL.

About 191 Curies (Ci) of tritium were released in liquid effluent to the Reactor Technology Complex (RTC) lined evaporations ponds during 1999-2000. During 1999, no tritium was discharged to the ponds at the Idaho Nuclear Technology and Engineering Center (INTEC); during 2000, $0.03 \mathrm{Ci}$ of tritium was discharged. Data for the total amount of tritium (in Ci) released in liquid effluent in 2001 are unavailable. Tritium concentrations in water samples decreased by as much as 8.3 picocuries per milliliter $(\mathrm{pCi} / \mathrm{mL}$ ) during 1999-2001 and ranged from $0.43 \pm 0.14$ to $13.6 \pm 0.6 \mathrm{pCi} / \mathrm{mL}$ in October 2001. The tritium plume extended southwestward in the general direction of ground-water flow. During 1999-2001, concentrations of tritium in water from wells near the southern boundary of the INL and from all wells south of the INL boundary were less than the reporting level. Radioactive decay, decreased tritium disposal, dilution from recharge, and discontinuation of the use of the infiltration ponds at RTC and the disposal well at INTEC and subsequent wastewater discharge to infiltration ponds at INTEC contributed to decreased concentrations of tritium in ground water at the INL during 1999-2001.

During 1999, less than $0.001 \mathrm{Ci}$ of strontium-90 was discharged at the INTEC or RTC; during 2000, $0.21 \mathrm{Ci}$ of strontium-90/yttrium-90 was discharged at the RTC. Data are unavailable for the amount of strontium-90 discharged in 2001. Strontium-90 concentrations in water from wells at the INL decreased or remained constant during 1999-2001. In October 2001, concentrations of strontium-90 in water from 19 wells exceeded the reporting level. Concentrations ranged from $2.1 \pm 0.7$ to $42.4 \pm 1.4$ picocuries per liter $(\mathrm{pCi} / \mathrm{L}$ ) and the plume extended southwestward in the general direction of ground-water flow. Strontium-90 has not been detected within the eastern Snake River Plain aquifer beneath the RTC. This can be explained partly by the exclusive use of waste-disposal ponds and lined evaporation ponds rather than the disposal well for radioactive-wastewater disposal at RTC.

During 1999-2001, concentrations of cesium-137, plutonium-238, and plutonium-239, -240 (undivided) in water from all wells sampled at the INL were less than the reporting level. The concentration of americium-241 in one sample was $0.003 \pm 0.001 \mathrm{pCi} / \mathrm{L}$, the reporting level for that constituent. Cobalt-60 was not detected in any samples collected during 1999-2001. 
Detectable concentrations of nonradioactive chemical constituents in water from the Snake River Plain aquifer at the INL were variable during 1999-2001.

During 1999-2001, water samples from several wells were analyzed for chromium. The concentration of chromium in water from well USGS 65 was $139 \mu \mathrm{g} / \mathrm{L}$ in October 2001, which exceeded the maximum contaminant level of $100 \mu \mathrm{g} / \mathrm{L}$. However, this was less than the concentration of $168 \mu \mathrm{g} / \mathrm{L}$ measured in 1998. Water samples from the other wells contained from 6.7 to $21.3 \mu \mathrm{g} / \mathrm{L}$ of chromium, an overall decrease in concentrations since 1998.

In October 2001, concentrations of sodium in water samples from most of the wells in the southern part of the INL were larger than the background concentration of $10 \mathrm{mg} / \mathrm{L}$, but were similar to or slightly less than October 1998 concentrations. The largest sodium concentration was $75 \mathrm{mg} / \mathrm{L}$ in water from well USGS 113.

In 2001, chloride concentrations in most water samples from the INTEC and the Central Facilities Area (CFA) exceeded background concentrations of 10 and $20 \mathrm{mg} / \mathrm{L}$, respectively. In October 2001, chloride concentrations in water from wells USGS 113 and CFA 1, both south of the INTEC, were 175 and $103 \mathrm{mg} / \mathrm{L}$, respectively. These concentrations were decreases from concentrations in October 1998. Chloride concentrations in water from wells near the RTC were less than $20 \mathrm{mg} / \mathrm{L}$. At the Radioactive Waste Management Complex (RWMC), chloride concentrations in water from wells USGS 88, 89, and 120 were 81, 40, and $22 \mathrm{mg} / \mathrm{L}$, respectively. Concentrations of chloride in all other wells near the RWMC were less than $19 \mathrm{mg} / \mathrm{L}$.

During 2001, concentrations of sulfate in water from two wells near the RTC, two wells near the RWMC, and one well near the CFA exceeded $40 \mathrm{mg} / \mathrm{L}$, the estimated background concentration of sulfate in the Snake River Plain aquifer at the INL.

In 2001, concentrations of nitrate in water from wells USGS 40, 43, 77, and CFA 1 were 16, 21, 16, and $14 \mathrm{mg} / \mathrm{L}$, respectively. These generally were smaller concentrations than those in 1998, with the exception of the concentration in water from well USGS 40, which had slightly increased. However, since 1981, there has been an overall decrease in nitrate concentration in water from these wells.

During 1999-2001, water samples from 12 wells were analyzed for fluoride; detected concentrations ranged from 0.2 to $0.3 \mathrm{mg} / \mathrm{L}$. These concentrations are similar to background concentrations, which indicates that wastewater disposal has not had an appreciable affect on fluoride concentrations in the Snake River Plain aquifer near the INTEC.

During 1999-2001, water samples from 36 wells at and near the INL were collected and analyzed for purgeable organic compounds (POCs). Ten POCs were detected. Concentrations of from 1 to 5 POCs in water samples from 17 wells exceeded the minimum reporting level (MRL). The MRL for some POCs was changed from 0.2 to $0.1 \mu \mathrm{g} / \mathrm{L}$ during 1998-2001, a change that resulted in detections of smaller concentrations than in previous years. In October 2001, concentrations of 1,1,1-trichloroethane in water from four wells near the INTEC exceeded the MRL, and water from RWMC wells contained detectable concentrations of 1,1,1-trichloroethane, carbon tetrachloride, chloroform, trichloroethylene, and tetrachloroethylene. During 1999-2001, water samples from three wells near Test Area North (ANP 9, No Name 1, and PSTF Test) were analyzed for POCs and concentrations of POCs in water from these wells were all less than the MRL.

\section{Acknowledgments}

The DOE's Radiological and Environmental Sciences Laboratory (RESL) at the INL provided radiochemical analyses of water samples. Technical staff at the RESL during 1999-2001 was supervised by R. Douglas Carlson, Director. The author is grateful for technical review of the manuscript by Roy C. Bartholomay, Supervisory Hydrologist, USGS; and Flint Hall, Environmental Scientist, State of Idaho Department of Environmental Quality. The author also is grateful to Betty J. Tucker, Hydrologic Technician, USGS, for conducting a data verification review.

\section{References Cited}

Ackerman, D.J., 1991, Transmissivity of the Snake River Plain aquifer at the Idaho National Engineering Laboratory, Idaho: U.S. Geological Survey Water-Resources Investigations Report 91-4058 (DOE/ID-22097), 35 p.

Anderson, S.R., 1991, Stratigraphy of the unsaturated zone and uppermost part of the Snake River Plain aquifer at the Idaho Chemical Processing Plant and Test Reactors Area, Idaho National Engineering Laboratory, Idaho:

U.S. Geological Survey Water-Resources Investigations Report 91-4010 (DOE/ID-22095), 71 p.

Anderson, S.R., Ackerman, D.J., Liszewski, M.J., and Freiburger, R.M., 1996, Stratigraphic data for wells at and near the Idaho National Engineering Laboratory, Idaho: U.S. Geological Survey Open-File Report 96-248 (DOE/ID-22127), 27 p., 1 diskette.

Anderson, S.R., Kuntz, M.A., and Davis, L.C., 1999, Geologic controls of hydraulic conductivity in the Snake River Plain aquifer at and near the Idaho National Engineering and Environmental Laboratory, Idaho: U.S. Geological Survey Water-Resources Investigations Report 99-4033 (DOE/ ID-22155), $38 \mathrm{p}$. 
Barraclough, J.T., and Jensen, R.G., 1976, Hydrologic data for the Idaho National Engineering Laboratory site, Idaho, 1971 to 1973: U.S. Geological Survey Open-File Report 75-318 (IDO-22055), $52 \mathrm{p}$.

Barraclough, J.T., Lewis, B.D., and Jensen, R.G., 1981, Hydrologic conditions at the Idaho National Engineering Laboratory, Idaho, emphasis: 1974-1978: U.S. Geological Survey Water-Resources Investigations Open-File Report 81-526 (IDO-22060), 77 p.

Barraclough, J.T., Robertson, J.B., and Janzer, V.J., 1976, Hydrology of the solid waste burial ground, as related to the potential migration of radionuclides, Idaho National Engineering Laboratory, with a section on Drilling and sample analyses, by L.G. Saindon: U.S. Geological Survey Open-File Report 76-471 (IDO-22056), 183 p.

Barraclough, J.T., Teasdale, W.E., and Jensen, R.G., 1967a, Hydrology of the National Reactor Testing Station, Idaho, 1965: U.S. Geological Survey Open-File Report (IDO-22048), $107 \mathrm{p}$.

Barraclough, J.T., Teasdale, W.E., Robertson, J.B., and Jensen, R.G., 1967b, Hydrology of the National Reactor Testing Station, Idaho, 1966: U.S. Geological Survey Open-File Report 67-12 (IDO-22049), 95 p.

Bartholomay, R.C., 1993, Concentrations of tritium and strontium-90 in water from selected wells at the Idaho National Engineering Laboratory after purging one, two, and three borehole volumes: U.S. Geological Survey WaterResources Investigations Report 93-4201 (DOE/ID-22111), $21 \mathrm{p}$.

Bartholomay, R.C., 1998, Distribution of selected radiochemical and chemical constituents in water from perched ground-water zones, Idaho National Engineering Laboratory, Idaho, 1992-95: U.S. Geological Survey WaterResources Investigations Report 98-4026 (DOE/ID-22145), $59 \mathrm{p}$.

Bartholomay, R.C., Hill, G.H., and Randolph, R.B., 1999, Statistical comparison of gross alpha-and gross beta-particle activity in water analyzed using two different laboratory methods: $199941^{\text {st }}$ Rocky Mountain Conference on Analytical Chemistry, Denver, Colo., Final program and abstracts, p. 132.

Bartholomay, R.C., Knobel, L.L., and Rousseau, J.P., 2003, Field methods and quality assurance plan for quality-ofwater activities, U.S. Geological Survey, Idaho National Engineering and Engineering Laboratory, Idaho: U.S. Geological Survey Open-File Report 03-42 (DOE/ID22182), $45 \mathrm{p}$.

Bartholomay, R.C., Knobel, L.L., Tucker, B.J., Twining B.V., 2001a, Chemical and radiochemical constituents in water from wells in the vicinity of the Naval Reactors Facility, Idaho National Engineering and Environmental Laboratory, Idaho, 1999: U.S. Geological Survey Open-File Report 01-27 (DOE/ID-22172), 37 p.
Bartholomay, R.C., Knobel, L.L., Tucker, B.J., Twining B.V., 2001b, Chemical and radiochemical constituents in water from wells in the vicinity of the Naval Reactors Facility, Idaho National Engineering and Environmental Laboratory, Idaho, 2000: U.S. Geological Survey Open-File Report 02-148 (DOE/ID-22178), 34 p.

Bartholomay, R.C., Orr, B.R., Liszewski, M.J., and Jensen, R.G., 1995, Hydrologic conditions and distribution of selected radiochemical and chemical constituents in water, Snake River Plain aquifer, Idaho National Engineering Laboratory, Idaho, 1989 through 1991: U.S. Geological Survey Water-Resources Investigations Report 95-4175 (DOE/ID-22123), 47 p.

Bartholomay, R.C., and Tucker, B.J., 2000, Distribution of selected radiochemical and chemical constituents in perched ground water, Idaho National Engineering and Environmental Laboratory, Idaho, 1996-98: U.S. Geological Survey Water-Resources Investigations Report 00-4222 (DOE/ID-22168), 51 p.

Bartholomay, R.C., Tucker, B.J., Ackerman, D.J., and Liszewski, M.J., 1997, Hydrologic conditions and distribution of selected radiochemical and chemical constituents in water, Snake River Plain aquifer, Idaho National Engineering Laboratory, Idaho, 1992 through 1995: U.S. Geological Survey Water-Resources Investigations Report 97-4086 (DOE/ID-22137), 57 p.

Bartholomay, R.C., Tucker, B.J., Davis, L.C., and Green, M.R., 2000, Hydrologic conditions and distribution of selected constituents in water, Snake River Plain aquifer, Idaho National Engineering and Environmental Laboratory, Idaho, 1996 through 1998: U.S. Geological Survey WaterResources Investigations Report 00-4192 (DOE/ID-22167), $52 \mathrm{p}$.

Bartholomay, R.C., and Williams, L.M., 1996, Evaluation of preservation methods for selected nutrients in ground water at the Idaho National Engineering Laboratory, Idaho: U.S. Geological Survey Water-Resources Investigations Report 96-4260 (DOE/ID-22131), 16 p.

Bennett, C.M., 1990, Streamflow losses and ground-water level changes along the Big Lost River at the Idaho National Engineering Laboratory, Idaho: U.S. Geological Survey Water-Resources Investigations Report 90-4067 (DOE/ ID-22091), $49 \mathrm{p}$.

Brennan, T.S., Campbell, A.M., Lehmann, A.K., O’Dell, I., 2000, Water resources data, Idaho, water year 1999volume 1. Great Basin and Snake River Basin above King Hill: U.S. Geological Survey Water-Data Report ID-99-1, 392 p.

Brennan, T.S., Campbell, A.M., Lehmann, A.K., O’Dell, I., 2001, Water resources data, Idaho, water year 2000volume 1. Great Basin and Snake River Basin above King Hill: U.S. Geological Survey Water-Data Report ID-00-1, $371 \mathrm{p}$. 
Busenberg, Eurybiades, Plummer, L.N., Doughten, M.W., Widman, P.K., and Bartholomay, R.C., 2000, Chemical and isotopic composition and gas concentrations of ground and surface water from selected sites at and near the Idaho National Engineering and Environmental Laboratory, Idaho, 1994 through 1997: U.S. Geological Survey Open-File Report 00-81 (DOE/ID-22164), 51 p.

Cassidy, G.B., 1984, Idaho National Engineering Laboratory industrial waste management information for 1983 and record-to-date: U.S. Department of Energy, Waste Management Programs Division, Idaho Operations Office Publication, DOE/ID-10057 (83), 99 p.

Cecil, L.D., Knobel, L.L., Wegner, S.J., and Moore, L.L., 1989, Evaluation of field sampling and preservation methods for strontium-90 in ground water at the Idaho National Engineering Laboratory: U.S. Geological Survey Water-Resources Investigations Report 89-4146 (DOE/ ID-22083), 24 p.

Cecil, L.D., Orr, B.R., Norton, T., and Anderson, S.R., 1991, Formation of perched ground-water zones and concentrations of selected chemical constituents in water, Idaho National Engineering Laboratory, Idaho, 1986-88: U.S. Geological Survey Water-Resources Investigations Report 91-4166 (DOE/ID-22100), 53 p.

Childress, C.J.O., Forman, W.T., Connor, B.F., and Maloney, T.J., 1999, New reporting procedures based on long-term method detection levels and some considerations for interpretations of water-quality data provided by the U.S. Geological Survey National Water Quality Laboratory: U.S. Geological Survey Open-File Report 99-193, 19 p.

Claassen, H.C., 1982, Guidelines and techniques for obtaining water samples that accurately represent the water chemistry of an aquifer: U.S. Geological Survey Open-File Report 82-1024, 49 p.

Currie, L.A., 1984, Lower limit of detection-definition and elaboration of a proposed position for radiological effluent and environmental measurements: U.S. Nuclear Regulatory Commission NUREG/CR-4007, 139 p.

Energy Research and Development Administration, 1977, Waste management operations, Idaho National Engineering Laboratory, Idaho: Final Environmental Impact Statement, Energy Research and Development Administration Report, ERDA-1536, 719 p.

Faires, L.M., 1993, Methods of analysis by the U.S. Geological Survey National Water Quality Laboratorydeterminations of metals in water by inductively coupled plasma-mass spectrometry: U.S. Geological Survey OpenFile Report 92-634, 28 p.

Fishman, M.J., ed., 1993, Methods of analysis by the U.S. Geological Survey National Water Quality Laboratorydetermination of inorganic and organic constituents in water and fluvial sediments: U.S. Geological Survey Open-File Report 93-125, 217 p.
Fishman, M.J., and Friedman, L.C., eds., 1989, Methods for determination of inorganic substances in water and fluvial sediments: U.S. Geological Survey Techniques of WaterResources Investigations, book 5, chap. A1, 545 p.

French, D.L., Lisee, D.J., and Taylor, K.A., 1997a, Idaho National Engineering and Environmental Laboratory nonradiological waste management information for 1996 and record-to-date: U.S. Department of Energy, Waste Management Programs Division, Idaho Operations Office Publication, DOE/ID-10057 (96) [variously paged].

French, D.L., Lisee, D.J., and Taylor, K.A., 1997b, Radioactive waste management information for 1996 and record-to-date: U.S. Department of Energy, Waste Management Programs Division, Idaho Operations Office Publication, DOE/ID-10054 (96) [variously paged].

French, D.L., Tallman, R.E., and Taylor, K.A., 1998, Idaho National Engineering Laboratory nonradiological waste management information for 1997 and record-to-date: U.S. Department of Energy, Waste Management Programs Division, Idaho Operations Office Publication, DOE/ID10057 (97) [variously paged].

French, D.L., Tallman, R.E., and Taylor, K.A., 1999a, Idaho National Engineering and Environmental Laboratory nonradiological waste management information for 1998 and record-to-date: U.S. Department of Energy, Waste Management Programs Division, Idaho Operations Office Publication, DOE/ID-10057 (98) [variously paged].

French, D.L., Tallman, R.E., and Taylor, K.A., 1999b, Radioactive waste management information for 1998 and record-to-date: U.S. Department of Energy, Waste Management Programs Division, Idaho Operations Office Publication, DOE/ID-10054 (98) [variously paged].

French, D.L., and Taylor, K.A., 1998, Radioactive waste information for 1997 and record-to-date: U.S. Department of Energy, Waste Management Programs Division, Idaho Operations Office Publication, DOE/ID-10054 (97) [variously paged].

Goerlitz, D.F., and Brown, Eugene, 1972, Methods for analysis of organic substances in water: U.S. Geological Survey Techniques of Water-Resources Investigations, book 5, chap. A3, 40 p.

Greene, M.J., and Tucker, B.J., 1998, Purgeable organic compounds in water at or near the Idaho National Engineering Laboratory, Idaho, 1992-95: U.S. Geological Survey Open-File Report 98-51 (DOE/ID-22146), 21 p.

Holdren, K.J., Becker, B.H., Hampton, N.L., Koeppen, L.D., Magnuson, S.O., Meyer, T.J., Olson, G.L., and Sondrup, A.J., 2002, Ancillary basis for risk analysis of the Subsurface Disposal Area: Idaho National Engineering and Environmental Laboratory, U.S. Department of Energy, Idaho Operations Office, INEEL/EXT-02-01125 [variously paged].

Jones, P.H., 1961, Hydrology of waste disposal, National Reactor Testing Station, Idaho, an interim report: U.S. Atomic Energy Commission, Idaho Operations Office Publication, IDO-22042-USGS, 152 p. 
Kjelstrom, L.C., 1995, Methods to estimate annual mean spring discharge to the Snake River between Milner Dam and King Hill, Idaho: U.S. Geological Survey WaterResources Investigations Report 95-4055, 9 p.

Knobel, L.L., and Mann, L.J., 1993, Sampling for purgeable organic compounds using positive-displacement piston and centrifugal submersible pumps-a comparative study: Ground Water Monitoring Review, Spring 1993, p. 142-148.

Knobel, L.L., Orr, B.R., and Cecil, L.D., 1992, Summary of background concentrations of selected radiochemical and chemical constituents in groundwater from the Snake River Plain aquifer, Idaho: estimated from an analysis of previously published data: Journal of the Idaho Academy of Science, v. 28, n. 1, p. 48-61.

Lewis, B.D., and Jensen, R.G., 1985, Hydrologic conditions at the Idaho National Engineering Laboratory, Idaho, 1979-1981 update: U.S. Geological Survey Hydrologic Investigations Atlas HA-674, 2 sheets.

Liszewski, M.J., and Mann, L.J., 1992, Purgeable organic compounds in ground water at the Idaho National Engineering Laboratory, Idaho, 1990 and 1991: U.S. Geological Survey Open-File Report 92-174 (DOE/ID22104), $19 \mathrm{p}$.

Lucius, J.E., Olhoeft, G.R., Hill, P.L., and Duke, S.K., 1989, Properties and hazards of 108 selected substances: U.S. Geological Survey Open-File Report 89-491, 538 p.

Mann, L.J., 1986, Hydraulic properties of rock units and chemical quality of water for INEL-1-a 10,365-foot deep test hole drilled at the Idaho National Engineering Laboratory, Idaho: U.S. Geological Survey Water-Resources Investigations Report 86-4020 (DOE/ID-22070), 23 p.

Mann, L.J., 1990, Purgeable organic compounds in ground water at the Idaho National Engineering Laboratory, Idaho-1988 and 1989: U.S. Geological Survey Open-File Report 90-367 (DOE/ID-22089), 17 p.

Mann, L.J., 1996, Quality-assurance plan and field methods for quality-of-water activities, U.S. Geological Survey, Idaho National Engineering Laboratory, Idaho: U.S. Geological Survey Open-File Report 96-615 (DOE/ID22132), $37 \mathrm{p}$.

Mann, L.J., and Cecil, L.D., 1990, Tritium in ground water at the Idaho National Engineering Laboratory, Idaho: U.S. Geological Survey Water-Resources Investigations Report 90-4090 (DOE/ID-22090), 35 p.

Mann, L.J., and Knobel, L.L., 1987, Purgeable organic compounds in ground water at the Idaho National Engineering Laboratory, Idaho: U.S. Geological Survey Open-File Report 87-766 (DOE/ID-22074), 23 p.

Mann, L.J., and Knobel, L.L., 1988, Concentrations of nine trace metals in ground water at the Idaho National Engineering Laboratory, Idaho: U.S. Geological Survey Open-File Report 88-332 (DOE/ID-22075), 17 p.
Morris, D.A., Barraclough, J.T., Chase, G.H., Teasdale, W.E., and Jensen, R.G., 1965, Hydrology of subsurface waste disposal, National Reactor Testing Station, Idaho, annual progress report, 1964: U.S. Atomic Energy Commission, Idaho Operations Office Publication, IDO-22047-USGS, $186 \mathrm{p}$.

Morris, D.A., Barraclough, J.T., Hogenson, G.M., Shuter, Eugene, Teasdale, W.E., Ralston, D.A., and Jensen, R.G., 1964, Hydrology of subsurface waste disposal, National Reactor Testing Station, Idaho, annual progress report, 1963: U.S. Atomic Energy Commission, Idaho Operations Office Publication, IDO-22046-USGS, 97 p.

Morris, D.A., Hogenson, G.M., Shuter, Eugene, and Teasdale, W.E., 1963, Hydrology of waste disposal, National Reactor Testing Station, Idaho, annual progress report, 1962: U.S. Atomic Energy Commission, Idaho Operations Office Publication, IDO-22044-USGS, 99 p.

Nace, R.L., Voegeli, P.T., Jones, J.R., and Morris, Deutsch, 1975, Generalized geologic framework of the National Reactor Testing Station, Idaho: U.S. Geological Survey Professional Paper 725-B, 48 p., 1 pl.

O’Dell, I., Lehmann, A.K., Campbell, A.M., Beattie, S.E., and Brennan, T.S., 2002, Water resources data, Idaho, water year 2001-volume 1. Great Basin and Snake River Basin above King Hill: U.S. Geological Survey Water-Data Report ID-01-1, $373 \mathrm{p}$.

Olmsted, F.H., 1962, Chemical and physical character of ground water in the National Reactor Testing Station, Idaho: U.S. Atomic Energy Commission, Idaho Operations Office Publication, IDO-22043-USGS, 142 p.

Orr, B.R., and Cecil, L.D., 1991, Hydrologic conditions and distribution of selected chemical constituents in water, Snake River Plain aquifer, Idaho National Engineering Laboratory, Idaho, 1986 to 1988: U.S. Geological Survey Water-Resources Investigations Report 91-4047 (DOE/ ID-22096), $56 \mathrm{p}$.

Orr, B.R., Cecil, L.D., and Knobel, L.L., 1991, Background concentrations of selected radionuclides, organic compounds, and chemical constituents in ground water in the vicinity of the Idaho National Engineering Laboratory: U.S. Geological Survey Water-Resources Investigations Report 91-4015 (DOE/ID-22094), 52 p.

Pittman, J.R., Jensen, R.G., and Fischer, P.R., 1988, Hydrologic conditions at the Idaho National Engineering Laboratory, 1982 to 1985: U.S. Geological Survey WaterResources Investigations Report 89-4008 (DOE/ID-22078), $73 \mathrm{p}$.

Robertson, J.B., Schoen, Robert, and Barraclough, J.T., 1974, The influence of liquid waste disposal on the geochemistry of water at the National Reactor Testing Station, Idaho, 1952-1970: U.S. Geological Survey Open-File Report 73-238 (IDO-22053), $231 \mathrm{p}$.

Sehlke, G., and Bickford, F.E., 1993, Idaho National Engineering Laboratory ground-water monitoring plan: EG\&G Idaho, Inc., and Golder Associates, Inc., DOE/ID10441, v. 1-2 [variously paged]. 
Stevens, H.H., Jr., Ficke, J.F., and Smoot, G.F., 1975, Water temperature-influential factors, field measurement, and data presentation: U.S. Geological Survey Techniques of Water-Resources Investigations, book 1, chap. D1, 65 p.

Stoller Corporation, 2002a, Idaho National Engineering and Environmental Laboratory site environmental report, calendar year 1999: U.S. Department of Energy, Idaho Operations Office, DOE/ID-12082 (99) [variously paged].

Stoller Corporation, 2002b, Idaho National Engineering and Environmental Laboratory site environmental report, calendar year 2000: U.S. Department of Energy, Idaho Operations Office, DOE/ID-12082 (00) [variously paged].

Stoller Corporation, 2002c, Idaho National Engineering and Environmental Laboratory site environmental report, calendar year 2001: U.S. Department of Energy, Idaho Operations Office, DOE/ID-12082 (01) [variously paged].

Timme, P.J., 1995, National Water Quality Laboratory, 1995 services catalog: U.S. Geological Survey Open-File Report 95-352, $120 \mathrm{p}$.

Tucker, B.J., and Orr, B.R., 1998, Distribution of selected radiochemical and chemical constituents in perched ground water, Idaho National Engineering Laboratory, Idaho, 1989-91, U.S. Geological Survey Water-Resources Investigations Report 98-4028 (DOE/ID-22144), 62 p.

U.S. Environmental Protection Agency, 1998, Protection of environment-Code of Federal Regulations 40: Washington, D.C., Office of the Federal Register, National Archives and Records Administration, Parts 136 to 149,808 p.

U.S. Environmental Protection Agency, 2001, Protection of environment-Code of Federal Regulations 40: Washington, D.C., Office of the Federal Register, National Archives and Records Administration, Parts 136 to 149, 833 p.

U.S. Geological Survey, 1985, National water summary, 1984-hydrologic events, selected water-quality trends, and ground-water resources: U.S. Geological Survey WaterSupply Paper 2275, 467 p.

U.S. Geological Survey, 2005, National water information system web data for Idaho: U.S. Geological Survey data available on the Web, accessed in 2005, at http://waterdata. usgs.gov/id/nwis/nwis.
Walker, F.W., Parrington, J.R., and Feiner, Frank, 1989, Nuclides and isotopes, chart of the nuclides (14th ed.): General Electric Company, Nuclear Energy Operations, $57 \mathrm{p}$.

Wegner, S.J., 1989, Selected quality assurance data for water samples collected by the U.S. Geological Survey, Idaho National Engineering Laboratory Idaho, 1980 to 1988: U.S. Geological Survey Water-Resources Investigations Report 89-4168 (DOE/ID-22085), 91 p.

Wershaw, R.L., Fishman, M.J., Grabbe, R.R., and Lowe, L.E., 1987, Methods for the determination of organic substances in water and fluvial sediments: U.S. Geological Survey Techniques of Water-Resources Investigations, book 5, chap. A3, 80 p.

Wilde, F.D., Radtke, D.B., Gibs, Jacob, and Iwatsubo, R.T., 1998, National field manual for the collection of waterquality data: U.S. Geological Survey Techniques of WaterResources Investigations Report, book 9, chaps. A1-A5 [variously paged].

Williams, L.M., 1996, Evaluation of quality assurance/quality control data collected by the U.S. Geological Survey for water-quality activities at the Idaho National Engineering Laboratory, Idaho, 1989 through 1993: U.S. Geological Survey Water-Resources Investigations Report 96-4148 (DOE/ID-22129), 116 p.

Williams, L.M., 1997, Evaluation of quality assurance/quality control data collected by the U.S. Geological Survey for water-quality activities at the Idaho National Engineering Laboratory, Idaho, 1994 through 1995: U.S. Geological Survey Water-Resources Investigations Report 97-4058 (DOE/ID-22136), 87 p.

Williams, L.M., Bartholomay, R.C., and Campbell, L.J., 1998, Evaluation of quality-assurance/quality-control data collected by the U.S. Geological Survey from wells and springs between the southern boundary of the Idaho National Engineering and Environmental Laboratory and the Hagerman area, Idaho, 1989 through 1995: U.S. Geological Survey Water-Resources Investigations Report 98-4206 (DOE/ID-22150), 83 p.

Wood, W.W., 1976, Guidelines for collection and field analysis of ground-water samples for selected unstable constituents: U.S. Geological Survey Techniques of Water-Resources Investigations, book 1, chap. D2, 24 p. 
This page left intentionally blank 
Manuscript approved for publication, April 4, 2006

Prepared by the USGS Publishing Network,

Publishing Service Center, Tacoma, Washington

Bill Gibbs

Donita Parker

Sharon Wahlstrom

For more information concerning the research in this report, contact the Idaho Water Science Center Director,

U.S. Geological Survey

230 Collins Road

Boise, Idaho 83702-4520

http://id.water.usgs.gov 


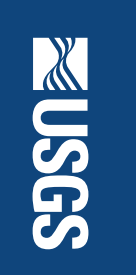

$\stackrel{\square}{\text { ஸे }}$

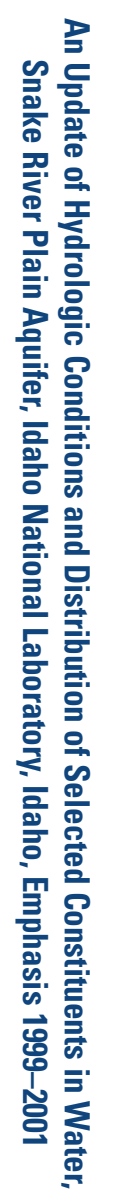

